



\section{Praktijkproef onderwaterdrains Wormer- en Jisperveld}

J.J.H. van den Akker $^{1}$, J.M.H. van Diggelen ${ }^{3}$, K. van Houwelingen ${ }^{2}$, J. van Kleef ${ }^{1}$, M. Pleijter ${ }^{1}$, A.J.P. Smolders ${ }^{3}$, L.G. Turlings ${ }^{4}$, S. van der Wielen ${ }^{4}$

1 Wageningen Environmental Research (Alterra)

2 Livestock Research Wageningen UR

3 B-Ware

4 Witteveen \& Bos

Dit onderzoek is uitgevoerd door Wageningen Environmental Research (Alterra) in opdracht van en gefinancierd door het Hoogheemraadschap Hollands Noorderkwartier.

Wageningen Environmental Research

Wageningen, november 2016

Rapport 2765

ISSN 1566-7197 
Van den Akker, J.J.H., J.M.H. van Diggelen, K. van Houwelingen, J. van Kleef, M. Pleijter, A.J.P. Smolders, L.G. Turlings, S. van der Wielen, 2016. Praktijkproef onderwaterdrains Wormer- en Jisperveld. Wageningen, Wageningen Environmental Research (Alterra), Rapport 2765. 68 blz.; 22 fig.; 3 tab.; 16 ref.

De grondwaterstand in een veenweideperceel kan in de zomer door de gewasverdamping decimeters onder het slootpeil dalen. Toepassing van onderwaterdrains (OWD) beperkt de grondwaterstandsdaling en daarmee veenoxidatie en bodemdaling en emissies van $\mathrm{CO}_{2}$ en $\mathrm{N}_{2} \mathrm{O}$. In de praktijkproef bleken OWD de drainage en daardoor draagkracht te verbeteren, maar ook de indringweerstand voor weidevogelsnavels te verhogen. Piekbuien werden voor een groter deel in de bodem opgevangen. De sloot- en grondwaterkwaliteit bleken bij OWD iets beter. Toepassing van OWD verbetert de slootinfiltratie sterk, maar deze bleef toch achter bij de verwachting. Waarschijnlijk wordt de infiltratie via OWD gehinderd door bagger. Daarom wordt inlaat via een collectordrain aangeraden.

Due to grassland evapotranspiration groundwater levels can be lowered decimeters below ditch water level. Use of submerged drains reduces the lowering of groundwater levels and so peat oxidation and subsidence and $\mathrm{CO}_{2}$ and $\mathrm{N}_{2} \mathrm{O}$ emissions. Submerged drains proved to increase the bearing capacity, however, also the penetration resistance for a meadowbird beak increased. The capacity to capture rain shower events increased. Groundwater and ditch water quality slightly improved. The infiltration of ditch water increased considerably, however, was less than expected. Probably this is caused by a hindered infiltration into the drain by sludge in the ditch. The use of a collector drain to regulate the inlet is recommended.

Trefwoorden: onderwaterdrain, veenoxidatie, bodemdaling, maaivelddaling, broeikasgasemissie, veenweide, veengrond, $\mathrm{CO}_{2}, \mathrm{~N}_{2} \mathrm{O}$

Dit rapport is gratis te downloaden van http://dx.doi.org/10.18174/396962 of op www.wur.nl/environmental-research (ga naar 'Wageningen Environmental Research' in de grijze balk onderaan). Wageningen Environmental Research verstrekt geen gedrukte exemplaren van rapporten.

2016 Wageningen Environmental Research (instituut binnen de rechtspersoon Stichting Wageningen Research), Postbus 47, 6700 AA Wageningen, T 03174807 00, E info.alterra@wur.nl, www.wur.nl/environmental-research. Wageningen Environmental Research is onderdeel van Wageningen University \& Research.

- Overname, verveelvoudiging of openbaarmaking van deze uitgave is toegestaan mits met duidelijke bronvermelding.

- Overname, verveelvoudiging of openbaarmaking is niet toegestaan voor commerciële doeleinden en/of geldelijk gewin.

- Overname, verveelvoudiging of openbaarmaking is niet toegestaan voor die gedeelten van deze uitgave waarvan duidelijk is dat de auteursrechten liggen bij derden en/of zijn voorbehouden.

Wageningen Environmental Research aanvaardt geen aansprakelijkheid voor eventuele schade voortvloeiend uit het gebruik van de resultaten van dit onderzoek of de toepassing van de adviezen.

Wageningen Environmental Research Rapport 2765 | ISSN 1566-7197

Foto omslag: J.J.H. van den Akker 


\section{Inhoud}

$\begin{array}{ll}\text { Samenvatting } & 5\end{array}$

$\begin{array}{lll}1 & \text { Inleiding } & 7\end{array}$

$\begin{array}{lll}1.1 & \text { Aanleiding } & 7\end{array}$

1.2 Doel $\quad 8$

$2 \quad$ Proeflocaties en metingen $\quad 9$

2.1 Proeflocaties 9

2.1.1 Kenmerken van de veenbodem 11

2.1.2 Inrichting primaire en secundaire proeflocaties 12

$\begin{array}{ll}2.1 .3 \text { Metingen } & 16\end{array}$

$3 \quad$ Resultaten en discussie $r$

3.1 Maaivelddaling $\quad 19$

3.2 Grondwaterstanden en slootpeilen $\quad 20$

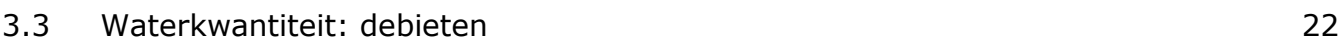

3.4 Waterkwaliteit $\quad 26$

3.4.1 Bodemkarakteristieken onderzoek perceel 26

3.4.2 Effecten OWD op de grondwater kwaliteit 26

3.4.3 Effecten OWD op het oppervlaktewater in de aangrenzende sloot $\quad 28$

$\begin{array}{lll}3.5 & \text { Bedrijfsvoering } & 29\end{array}$

$\begin{array}{lll}3.6 & \text { Geschiktheid voor weidevogels } & 30\end{array}$

3.7 Vergelijking met de pilot Zeevang $3 \quad 32$

$\begin{array}{lll}3.8 & \text { Kosten en baten OWD } & 34\end{array}$

4 Conclusies en Aanbevelingen $\quad 35$

4.1 Conclusies $\quad 35$

4.2 Aanbevelingen 36

$\begin{array}{ll}\text { Literatuur } & \mathbf{3 8}\end{array}$

Bijlage 1 Boringen Wormer- en Jisperveld 39

Bijlage 2 Metingen doorlatendheden en berekening drainafstanden $\quad 41$

Bijlage 3 Meetresultaten draagkracht, indringweerstanden en $\begin{array}{ll}\text { grashoogten } & 49\end{array}$

Bijlage 4 Waterkwaliteit praktijkproef onderwaterdrains Wormer- Jisperveld 



\section{Samenvatting}

Het beperken van de veenafbraak (oxidatie) is een van de belangrijkste doelstellingen van het Wormeren Jisperwaterproject, omdat dit een oorzaak is van baggervorming, verslechtering van de waterkwaliteit, bodemdaling en $\mathrm{CO}_{2}$ - en $\mathrm{N}_{2} \mathrm{O}$-emissies. Een probleem is dat in langdurige droge perioden de infiltratie van slootwater in het perceel de verdamping van het gras bij lange niet kan bijhouden, waardoor de grondwaterstand diep kan wegzakken tot decimeters onder het slootpeil. Zuurstof kan dan diep in het veenprofiel doordringen, waardoor de veenafbraak sterk wordt bevorderd. Om de veenafbraak te beperken, moet de grondwaterspiegel omhoog, zodat het veen zo veel mogelijk onder water geconserveerd blijft. Een mogelijkheid om het slootwater veel effectiever in het perceel te infiltreren, is het toepassen van onderwaterdrains (OWD). Onderwaterdrains trekken als het ware de grondwaterstand naar het slootpeil toe door infiltratie in droge perioden en drainage in natte perioden. Voor de melkveehouderij is de intensieve drainage in natte perioden een belangrijk pluspunt van OWD. Begin 2013 is een proef met OWD gestart in het Wormer- en Jisperveld nabij Wormer, met als doel het effect van de toepassing van OWD te onderzoeken op de maaivelddaling; de watervraag in de zomer; de waterkwaliteit; de bedrijfsvoering (draagkracht) en de geschiktheid voor weidevogels.

De gemiddelde maaivelddaling bleek tijdens de meetperiode 2013-2016 slechts 1 tot $2 \mathrm{~mm}$ per jaar te zijn, waarbij de referentie iets meer leek te zakken dan het perceeldeel met OWD, maar de zeer geringe verschillen maken het trekken van conclusies onmogelijk. Dat OWD de veenafbraak en maaivelddaling reduceren, blijkt daarom alleen uit maaivelddalingsmetingen bij andere pilots met OWD. Een belangrijke oorzaak voor de geringe maaivelddaling bij zowel de referentie als de OWD is het feit dat de laatste jaren de zomers veel natter zijn dan het langjarige gemiddelde. Uit de grondwaterstandmetingen bleek dat de drainerende werking van de OWD goed functioneert. Uit de draagkrachtmetingen bleek dan ook dat deze bij de OWD toenam en daarmee voldoet aan de verwachtingen van de melkveehouderij. De infiltrerende werking van de OWD bleek met ca. $1 \mathrm{~mm} /$ dag ongeveer $1 / 3^{\mathrm{e}}$ te zijn van de verwachte infiltratie. Waarschijnlijk wordt dit veroorzaakt door de grote hoeveelheid bagger in de sloot (ondanks een intensief baggerbeleid). Desondanks was de infiltratie bij de OWD twee- tot driemaal hoger dan bij de referentie. Toch bleken de diepste grondwaterstanden bij de OWD op te treden. De grotere infiltratie kan bij OWD wel tot gevolg hebben dat de veenlaag boven het grondwater veel natter en zuurstofarmer blijft dan bij de referentie.

Piekafvoeren bij hevige regenbuien blijken bij de referentie duidelijk groter te zijn dan bij de OWD. Door de drainerende werking van OWD hebben de perceeldelen met OWD bij het begin van de piekbui een lagere grondwaterstand en daardoor meer bergingsmogelijkheid dan de referentie, terwijl bij de referentie de berging al snel vol zit en het regenwater via het maaiveld, greppel en greppelbuis in de sloot belandt. Indien kort voor de piekbui mest is uitgereden, kan dit leiden tot grote nutriëntenpieken in de sloot. Door het incidentele karakter is de kans klein dat zo'n nutriëntenpiek toevallig in een waterkwaliteitsmeting tot uitdrukking komt. Het blijkt dat in het algemeen zowel het slootwater als het grondwater bij OWD een wat betere kwaliteit heeft dan bij de referentie. Dit komt overeen met metingen in andere pilots en algemene modelberekeningen.

Het blijkt dat de draagkracht bij OWD eerder in het seizoen voldoende is voor berijden of beweiden dan bij de referenties. De agrariër merkt vooral dat er minder plasvorming is bij OWD. De agrariër staat positief tegenover OWD. Door OWD neemt de indringweerstand toe, waardoor een groter deel van het perceel minder geschikt wordt voor foerageren door weidevogels. Andere mogelijke nadelige gevolgen van OWD voor weidevogels, zoals een vroeger tijdstip met een hoge en zware snede en vroegere bloei, traden niet op.

Om infiltratie van bagger in de OWD te voorkomen, wordt aanbevolen om de OWD rechtstreeks of via een verzameldrain aan te sluiten op in- en uitlaatpunten, waar voorzieningen kunnen worden getroffen om alleen "schoon" water te infiltreren. Dit biedt ook mogelijkheden om met behulp van pompen of een verbinding met een hoogwatersloot met een hogere waterdruk veel effectiever te infiltreren. Daarnaast verbetert het de mogelijkheden om bijvoorbeeld een perceel tijdelijk optimaal geschikt te maken voor weidevogels. 


\section{$1 \quad$ Inleiding}

\section{$1.1 \quad$ Aanleiding}

Het Hoogheemraadschap Hollands Noorderkwartier heeft gedurende twaalf jaren het project Wormeren Jisperwater uitgevoerd, dat in 2015 is afgerond. Het project speelt in de polder Wormer, Jisp en Neck in de gemeente Wormerland. Voor gedetailleerde informatie wordt verwezen naar de projectwebsite: http://www.wormerenjisperwater.nl/. Een belangrijk doel van het project was beperking van de maaivelddaling, het verbeteren van de waterkwaliteit en het verminderen van de problemen met bagger. Deze problemen hebben een direct verband met het grootste probleem in veengebieden, namelijk de veenafbraak, waardoor het gebied steeds verder omlaag zakt. Veenafbraak leidt niet alleen tot bodemdaling, maar ook tot grote emissies van $\mathrm{CO}_{2}$ en $\mathrm{N}_{2} \mathrm{O}$, problemen met de waterkwaliteit en productie van bagger. In de bovenste, deels veraarde, veenlaag die boven de grondwaterstand ligt, dringt lucht - dus zuurstof - in het veen, waardoor het veen dat bijna volledig uit organisch materiaal bestaat, biologisch afbreekt. Dit wordt ook wel veenoxidatie of "verbranden" van het veen genoemd. Het overgrote deel van de veenoxidatie vindt in het zomerhalfjaar plaats, omdat de verdamping van het gras veel groter kan zijn dan de neerslag, zodat de grondwaterstand sterk kan dalen. Doordat de infiltratie van water vanuit de sloten door de lage doorlatendheid van het veen beperkt is, kan de grondwaterstand in het veen decimeters onder het slootpeil zakken. Tegen het einde van de zomer zijn de grondwaterstanden vaak het laagst en is de grond op die diepte het sterkst opgewarmd. Dan zijn de omstandigheden voor veenafbraak optimaal en vindt de grootste afbraak - en daarmee bodemdaling en GHG-emissies - plaats. Bij voldoende zuurstofaanvoer kan ook pyrietoxidatie plaatsvinden, waarbij sulfaat $\left(\mathrm{SO}_{4}\right)$ wordt gevormd. Bij de afbraak van veen komt naast $\mathrm{CO}_{2}$ veel stikstof en sulfaat vrij. Sulfaat lost goed op in water en kan bij ontbreken van zuurstof uit de lucht dienen als zuurstofbron voor afbraak in verzadigd veen, zodat nog extra veenafbraak kan plaatsvinden als het veen in het najaar (weer) verzadigd is. De vrijgekomen gemineraliseerde stikstof wordt deels opgenomen door het gras en kan deels worden omgezet in het sterke broeikasgas $\mathrm{N}_{2} \mathrm{O}$ (lachgas) en kan deels naar diepere veenlagen infiltreren of samen met een deel van het sulfaat uitspoelen naar de sloot. Het sulfaat kan in de sloot weer fosfaat vrijmaken uit de onderwaterbodem. Het resultaat is voedselrijk water met algengroei en weinig zuurstof. Samen met andere plantengroei, uitgespoelde veendeeltjes en afkalving van slootoevers vormt dit een bron voor baggeraanwas.

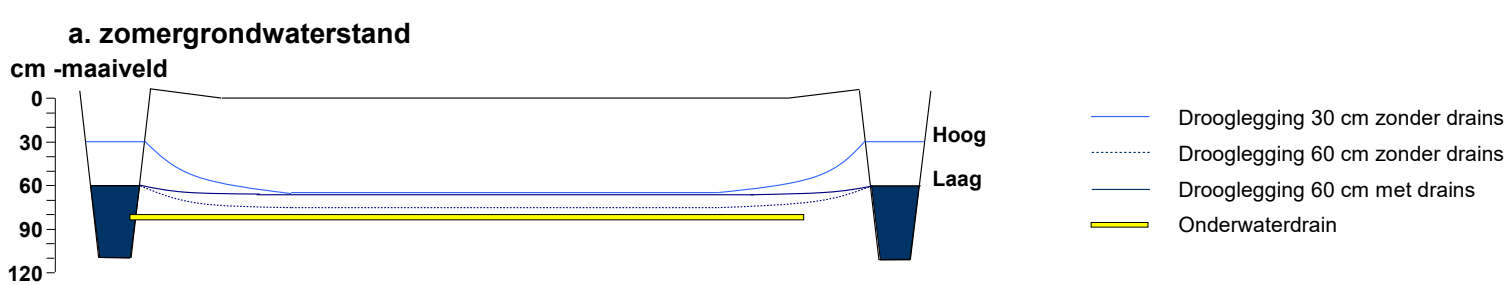

b. wintergrondwaterstand

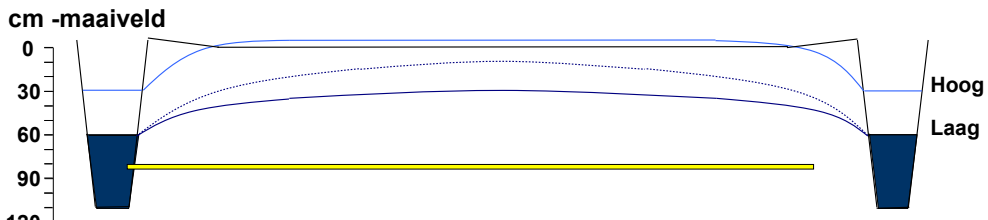

Figuur 1 Schematische weergave van de werking van OWD. De drains hebben veelal een diameter van $6 \mathrm{~cm}$ en liggen op een onderlinge afstand van 4 tot $6 \mathrm{~m}$. In droge perioden infiltreert slootwater en wordt de grondwaterstand zo veel mogelijk naar slootpeil getrokken. In natte perioden fungeren de OWD als drainagemiddel om de grondwaterstand zo veel mogelijk te verlagen tot slootpeil. 
Om de belangrijkste doelstellingen van het Wormer- en Jisperwaterproject - namelijk verbetering van de waterkwaliteit en beperking van baggervorming - te bereiken, moeten dus de veenafbraak en daarmee gepaard gaande bodemdaling en $\mathrm{CO}_{2}$ - en $\mathrm{N}_{2} \mathrm{O}$-emissies zo veel mogelijk worden beperkt. Om de veenafbraak te beperken, moet de grondwaterspiegel zo hoog mogelijk worden gehouden. Een mogelijkheid om dit te doen, is het toepassen van onderwaterdrains (zie Figuur 1), waarmee het slootwater veel effectiever in het perceel infiltreert. Over de toepassing, werking en aanleg van onderwaterdrains is een DeltaFactsheet gemaakt door Hendriks en Van den Akker (2015): http://deltaproof.stowa.nl/Publicaties/deltafact/Onderwaterdrains.aspx.

Het toepassen van onderwaterdrains roept echter vragen op ten aanzien van de effecten daarvan op het watersysteem, zowel kwantitatief als kwalitatief, het effect op de bedrijfsvoering van de melkveehouder en het effect op weidevogels. Dit vormt de aanleiding voor het Hoogheemraadschap om experimenteel te laten onderzoeken wat de effecten zijn van het toepassen van onderwaterdrains in het Wormer- en Jisperveld op deze aspecten en hoe effectief onderwaterdrains zijn op de beperking van de maaivelddaling. Bij de keuze van de locatie heeft ook een belangrijke rol gespeeld dat het Wormer- en Jisperveld afwijkt van gebieden waar al eerder onderzoek heeft plaatsgevonden: er is veel veenmos en het gebied kent een recent brak verleden, waardoor onder andere door de invloed van chloride en sulfaat veel geochemische processen anders verlopen dan in eerder onderzochte locaties.

\subsection{Doel}

Doel van de praktijkproef is een praktische en onderbouwde inschatting van de voor- en nadelen van de toepassing van onderwaterdrains in het Wormer- en Jisperveld. Dit doel is in overleg met de Agrarische Natuurvereniging Water, Land en Dijken en het Hoogheemraadschap Hollands Noorderkwartier vastgesteld. Het doel is niet om met een wetenschappelijk experiment de kennis op het gebied van onderwaterdrains uit te breiden, maar de voor- en nadelen van de toepassing van onderwaterdrains dienen wel op een juiste wijze met feiten te worden onderbouwd. De metingen worden beknopt en overzichtelijk gerapporteerd en voorzien van "gezond verstand"-analyses. Op basis van de bevindingen wordt duidelijk gemaakt wat de voor- en nadelen zijn van onderwaterdrains in het Wormer- en Jisperveld.

Aandachtsgebieden voor het effect van de toepassing van onderwaterdrains zijn:

- de maaivelddaling;

- de watervraag in de zomer;

- de waterkwaliteit;

- de bedrijfsvoering (draagkracht);

- de geschiktheid voor weidevogels. 


\section{Proeflocaties en metingen}

\section{$2.1 \quad$ Proeflocaties}

In het startoverleg met Hollands Noorderkwartier en Natuurmonumenten zijn geschikte percelen op kaart geïdentificeerd. In het kader van het project Wormer- en Jisperwater hebben enkele boeren bij Hollands Noorderkwartier aangegeven geïnteresseerd te zijn in onderwaterdrains. De eigenaren van enkele geschikte percelen zijn benaderd. Uiteindelijk bleven zeven percelen over in twee onderbemalingen van de heer Klaver, in het zuidelijk deel van het Wormer- en Jisperveld. Deze zijn weergegeven in Figuur 2.

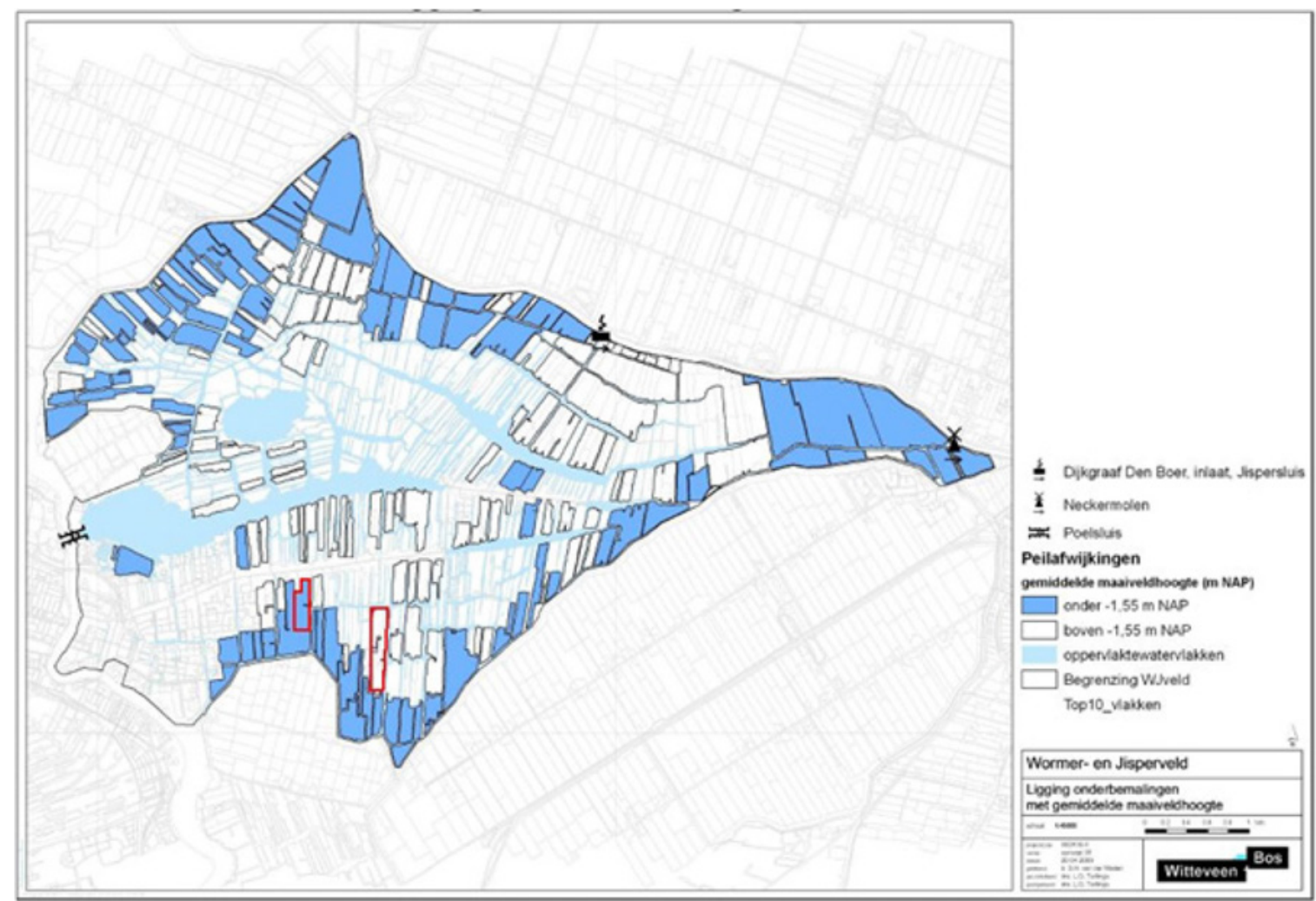

Figuur 2 Percelen voor proeflocaties in het Wormer- en Jisperveld, aangegeven in rood. In Figuur 3 zijn de locaties in meer detail aangegeven.

Vervolgens zijn de zeven percelen beoordeeld (zie Figuur 3). In de tabel staan de maximale lengtes en breedtes van de percelen weergegeven.

\begin{tabular}{|c|c|c|c|c|}
\hline $\begin{array}{c}\text { Perceel } \\
\text { No. }\end{array}$ & $\begin{array}{l}\text { lengte } \\
{[\mathrm{m}]}\end{array}$ & $\begin{array}{c}\text { breedte } \\
{[\mathrm{m}]}\end{array}$ & oppervlakte [m2] & $\begin{array}{c}\text { oppervlakte } \\
\text { [ha] }\end{array}$ \\
\hline 1 & 380 & 53 & 20340 & 2,0 \\
\hline 2 & 290 & 95 & 27207 & 2,7 \\
\hline 3 & 505 & 53 & 27677 & 2,8 \\
\hline 4 & 515 & 101 & 42284 & 4,2 \\
\hline 5 & 144 & 67 & 9553 & 1,0 \\
\hline 6 & 232 & 81 & 19560 & 2,0 \\
\hline 7 & 237 & 146 & 35502 & 3,6 \\
\hline
\end{tabular}


Zoals uit Figuur 3 blijkt, zijn de percelen onregelmatig van vorm.

De percelen $1 \mathrm{t} / \mathrm{m} 4$ vormen één blok ten zuiden van de boerderij van de heer Klaver, omgeven door het polderpeil. Op de kop van perceel 2 ligt een 40 meter brede strook met natuurwaarden die apart wordt beheerd. Het blok met de percelen $1 \mathrm{t} / \mathrm{m} 4$ wordt doorsneden door een ca. 8 meter brede sloot waarin een onderbemaling wordt gehandhaafd door een windmolen (blauw ingekleurd cirkeltje). De sloten met onderbemaling worden weergegeven door een donkerblauwe doorgetrokken lijn. Tijdens het veldbezoek bedroeg het verschil tussen onderbemaling en polderpeil $27 \mathrm{~cm}$ (gemeten bij de molen).

De percelen 5 t/m 7 liggen 600 meter naar het westen direct onder het dorp. Perceel 5 wordt aan drie zijden omgeven door onderbemalen sloten, terwijl perceel 6 alleen aan de westzijde aan een onderbemalen sloot grenst. Aan de oostzijde is de drooglegging minimaal. Perceel 7 is even breed als 5 en 6 tezamen en wordt alleen aan de westzijde begrensd door een onderbemalen sloot. Deze onderbemaling vindt plaats met een pomp die bijna 200 meter ten zuiden van perceel 7 staat opgesteld (lichtgroen aangegeven).

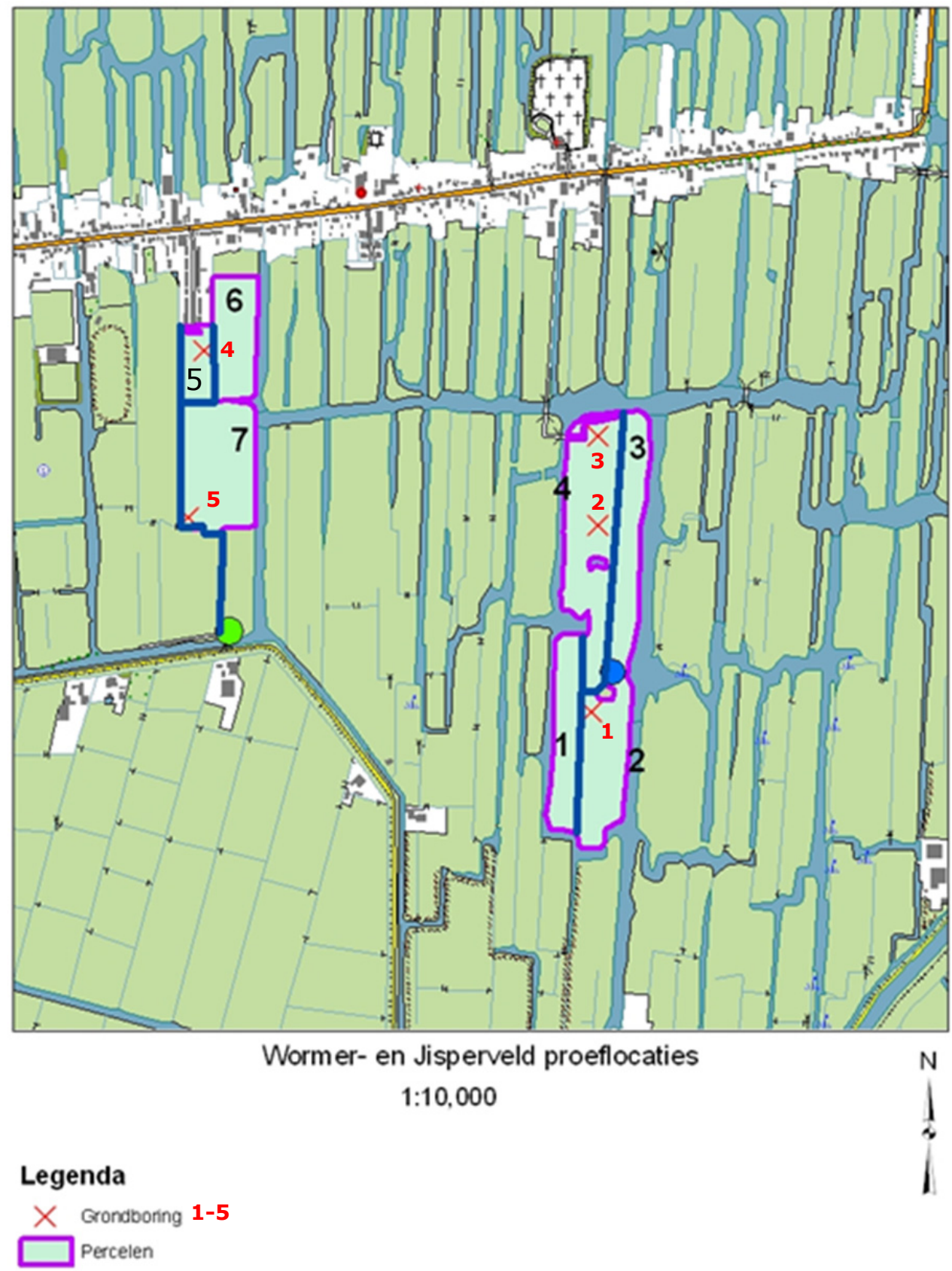

Figuur 3 Percelen $1 \mathrm{t} / \mathrm{m} 7$ voor proeflocaties Wormer- en Jisperveld. De hoofdlocatie is aangelegd op de percelen 5 en het zuidelijk deel van perceel 6 . Nevenlocaties zijn aangelegd op de percelen $1 \mathrm{t} / \mathrm{m} 4$. 


\subsubsection{Kenmerken van de veenbodem}

Bij de locatiekeuze ging de voorkeur uit naar veenmosveen. Voor Noord-Holland is een onderzoek naar de toepassing van onderwaterdrains in veenmosveen zeer relevant, omdat een groot deel van het veen ten noorden van Amsterdam uit veenmosveen bestaat. Bovendien zijn er al verschillende pilots geweest op andere veensoorten in Zuid-Holland, Utrecht en Noord-Holland (Van den Akker et al., 2010, 2013, Hendriks et al., 2013, Hoving et al., 2008, 2009, 2011, 2013, 2015). Veenmosveen heeft in het algemeen een duidelijk lagere waterdoorlatendheid en houdt water beter vast dan andere veensoorten. De dichtheid en de hoeveelheid minerale delen van veenmosveen zijn lager dan van andere veensoorten. Veenmosveen is vooral kwetsbaar voor oxidatie bij langdurige droge perioden. In Nederland zijn veel veenpakketten bedekt met een dun kleidek. Deze klei is op het veen afgezet tijdens overstromingen door rivieren of de zee. Indien het kleidek dunner is dan $40 \mathrm{~cm}$ worden deze gronden nog geclassificeerd als veengronden. De voorkeur ging in dit project uit naar veen zonder kleidek, omdat veen zonder kleidek kwetsbaarder is voor veenoxidatie. Dit is niet omdat de klei het onderliggende veen afsluit van de buitenlucht met zuurstof, maar simpelweg omdat het kleidek niet meedoet aan de oxidatie. Verder werd gezocht naar een veenpakket van minimaal $2 \mathrm{~m}$ dikte, zodat de stroming van water in het veen representatief is voor andere dikke veenpakketten.

\section{Tabel 1 Profielbeschrijvingen boringen $1 \mathrm{t} / \mathrm{m} 5$ (zie Figuur 3).}

\begin{tabular}{|c|c|c|c|c|c|}
\hline Boring nr & Laag_ nr & $\begin{array}{c}\text { Boven- } \\
\text { grens } \\
\text { (cm) }\end{array}$ & $\begin{array}{l}\text { Onder- } \\
\text { grens } \\
(\mathrm{cm})\end{array}$ & $\begin{array}{l}\text { Org. } \\
\text { stof } \\
(\%)\end{array}$ & Opmerking \\
\hline 1 & 1 & 0 & 5 & 36 & zodelaag; donkergrijs, iets roestig. venige klei \\
\hline 1 & 2 & 5 & 15 & 20 & donkergrijsbruin, roestig. zware kalkloze humusrijke klei \\
\hline 1 & 3 & 15 & 40 & 65 & zwart veraard veen \\
\hline 1 & 4 & 40 & 65 & 70 & zwartbruin, geoxideerd zeggeveen \\
\hline 1 & 5 & 65 & 80 & 75 & roodbruin, gereduceerd zeggeveen \\
\hline 1 & 6 & 80 & 190 & 85 & bruin, gereduceerd veenmosveen, iets zegge \\
\hline 1 & 7 & 190 & 240 & 70 & geelbruin, gereduceerd rietzeggeveen \\
\hline 2 & 1 & 0 & 20 & 32 & donkergrijsbruin, iets roestige humusrijke kalkloze zware klei \\
\hline 2 & 2 & 20 & 40 & 55 & zwart veraard veen \\
\hline 2 & 3 & 40 & 55 & 70 & zwartbruin, geoxideerd zeggeveen \\
\hline 2 & 4 & 55 & 200 & 80 & bruin, gereduceerd veenmosveen. takjes, ook iets zegge \\
\hline 2 & 5 & 200 & 240 & 70 & geelbruin, gereduceerd rietzeggeveen \\
\hline 3 & 1 & 0 & 15 & 36 & donkergrijsbruin venige klei \\
\hline 3 & 2 & 15 & 20 & 32 & donkergrijsbruin iets roestige humusrijke kalkloze zware klei \\
\hline 3 & 3 & 20 & 40 & 55 & zwart veraard veen \\
\hline 3 & 4 & 40 & 55 & 70 & zwartbruin, geoxideerd zeggeveen \\
\hline 3 & 5 & 55 & 200 & 80 & bruin, gereduceerd veenmosveen. takjes, ook iets zegge \\
\hline 3 & 6 & 200 & 240 & 70 & geelbruin, gereduceerd rietzeggeveen \\
\hline 4 & 1 & 0 & 15 & 36 & donkergrijsbruin veraard kleiig veen. Puinrestjes \\
\hline 4 & 2 & 15 & 30 & 55 & zwartbruin bijna volledig veraard veen \\
\hline 4 & 3 & 30 & 50 & 70 & bruin veenmosveen met takjes \\
\hline 4 & 4 & 50 & 190 & 90 & roodbruin, gereduceerd veenmosveen. Losse structuur \\
\hline 4 & 5 & 190 & 240 & 75 & bruin rietzeggeveen \\
\hline 5 & 1 & 0 & 10 & 32 & donkergrijsbruin, iets roestige humusrijke kalkloze zware klei \\
\hline 5 & 2 & 10 & 35 & 40 & zwart, veraard kleiig veen, iets roestig \\
\hline 5 & 3 & 35 & 50 & 65 & zwartbruin geoxideerd zeggeveen \\
\hline 5 & 4 & 50 & 80 & 75 & bruinzeggeveen \\
\hline 5 & 5 & 80 & 115 & 80 & bruin, gereduceerd veenmosveen. takjes, ook iets zegge \\
\hline 5 & 6 & 115 & 240 & 70 & geelbruin gereduceerd rietzeggeveen \\
\hline
\end{tabular}

Van de 7 percelen bleken de percelen 5 en 6 hieraan het beste te voldoen, echter perceel 6 grenst aan het zeer hoge polderpeil. Perceel 5 grenst aan de noordzijde aan een parkeerterrein en aan drie zijden aan sloten met een onderbemaling en bleek het geschiktst om in te richten voor de intensievere metingen. 
Het bodemprofiel van de percelen 5 en 7 bestaat uit een kleiige bovengrond van 15-20 cm dikte waarvan het organische stofgehalte van de bebouwing van Wormer naar het zuiden toe langzaam afneemt. Bij Wormer is de bovengrond kleiig veen. Richting zuiden neemt het kleigehalte toe en wordt de bovenlaag venige klei. Het minerale deel in de bovengrond bestaat uit matig zware tot zeer zware klei (lutum ca. 50\%). Het organische stofgehalte varieert van $30 \%$ in het zuiden tot $40 \%$ nabij Wormer. Bij een lutumgehalte van $50 \%$ ligt de grens tussen moerig en minerale grond bij een organische stofgehalte van 35\%. De kleiige bovengrond is nabij Wormer dus moerig (koopveengronden) en gaat naar het zuiden toe - richting boring 5 - geleidelijk over in een humusrijke minerale bovengrond (weideveengrond). Direct onder de bovengrond ligt een ca. $20 \mathrm{~cm}$ dikke veenlaag bestaande uit verweerd veen, waarin geen duidelijke plantenresten zijn te onderscheiden. In deze laag is vaak nog de mariene invloed in de vorm van kleibijmenging aanwezig. Tussen 40 en $60 \mathrm{~cm}-\mathrm{mv}$. komt een laag half veraard veen voor. De overgang tussen het verweerde materiaal en het gereduceerde veen ligt in dit traject. De veensoort in deze horizont is overwegend zeggeveen. Vanaf $60 \mathrm{~cm}-\mathrm{mv}$. raakt het veen volledig gereduceerd. Om deze reden wordt de gemiddelde laagste grondwaterstand (GLG) geschat op 60 à $65 \mathrm{~cm}-\mathrm{mv}$. De veensoort wordt dieper in het profiel geleidelijk armer en gaat over van zeggeveen naar veenmosveen. Het veenmosveen kenmerkt zich door de aanwezigheid van takjes en veenmos. In het veenmosveen zijn bij meerdere boringen ook zegges aangetroffen, hetgeen duidt op een niet "hoog" ontwikkelde veenmosveen koepel. Op ca. $2 \mathrm{~m}$-mv. vindt er een vrij scherpe overgang plaats van het veenmosveen/zeggeveen naar rietzeggeveen. Rietzeggeveen is duidelijk herkenbaar door de rietknopen die goed zichtbaar in de plantenresten aanwezig zijn. Het rietzeggeveen is relatief slibrijk. Naar het zuiden en zuidwesten toe wordt de laag met veenmosveen/zeggeveen dunner en komt het rietzeggeveen hoger in het profiel voor. Op de meest zuidwestelijk genomen boorlocatie (boring 5) begint het rietzeggeveen op een diepte van $115 \mathrm{~cm}-\mathrm{mv}$.

De veengronden van de percelen 1, 2, 3 en 4 zijn geclassificeerd als weideveengronden. Weideveengronden kenmerken zich door een zeer donkere humusrijke of zeer humeus kleidek (minerale eerdlaag) met een dikte van minimaal $15 \mathrm{~cm}$, die binnen $40 \mathrm{~cm}$ gewoonlijk geleidelijk overgaat in moerig materiaal (veen). De kleilaag is daarmee duidelijk minder uitgesproken dan bij waardveengronden, waarvan de kleilaag duidelijk minder humeus en daarom ook veel grijzer is en die een vrij scherpe overgang heeft van kleidek naar het veen eronder. Wat betreft de draagkracht en geschiktheid voor weidevogels vormt de secundaire proeflocatie een belangrijke aanvulling op de primaire locatie, omdat deze veengronden met een dunne kleilaag in de toplaag representatief zijn voor grote delen van het Wormer- en Jisperveld. Een kleilaag reageert veel sterker op vernatting en verdroging dan een veenlaag. Een drogere situatie door toepassing van onderwaterdrains zou eerder kunnen leiden tot hogere indringweerstanden, dus tot meer draagkracht, dan bij een koopveengrond die geen kleilaag heeft. Voor de agrariër is dit gunstig, maar voor weidevogels zou de hogere indringweerstand een belemmering kunnen vormen voor succesvol fourageren. Ook zou juist op weideveengronden het gras bij toepassing van onderwaterdrains sneller kunnen gaan groeien en eerder bloeien, wat nadelig is voor jonge kuikentjes van weidevogels.

Het Wormer- en Jisperveld is een wegzijgingsgebied. De wegzijging is niet groot en geen grote post op de waterbalans. De noordoostelijke en zuidoostelijke rand van het Wormer- en Jisperveld grenzen aan diepe polders. Het feit dat de randgebieden langs de diepe polders lager liggen dan het midden van het Wormer- en Jisperveld wijst erop dat de wegzijging daar groter is. De grondwaterstanden zakken daar verder weg dan je op basis van de slootpeilen zou inschatten, wat leidt tot een snellere maaivelddaling. Toepassing van onderwaterdrains zal in een dergelijk geval de maaivelddaling sterker en efficiënter beperken dan slootpeilen verhogen.

\subsubsection{Inrichting primaire en secundaire proeflocaties}

Omdat de percelen 5 en 6 het geschiktst bleken, is daar de primaire proeflocatie gepland, waaraan intensief wordt gemeten. Bij de primaire proeflocatie wordt gemeten aan maaivelddaling, draagkracht, geschiktheid voor weidevogels, waterkwantiteit en aan de waterkwaliteit. De balansen van water en nutriënten worden zo veel mogelijk sluitend gemaakt. Bij de waterkwantiteit wordt speciaal aandacht besteed aan de extra waterbehoefte (meer inlaat vanuit het hoofdpeilvak) die door de toepassing van onderwaterdrains kan ontstaan. 
De zuidoostelijke onderbemaling met de percelen 1, 2, 3 en 4 is als secundaire proeflocatie ingericht, met delen met en zonder onderwaterdrains. De metingen zijn hier veel minder intensief en gericht op de vraag hoe het staat met de voordelen voor de boer (draagkracht) en de geschiktheid voor weidevogels (indringweerstanden).

Voorafgaand aan de inrichting van de beide proeflocaties is een vooronderzoek uitgevoerd. Hiervoor is een uitgebreide serie boringen uitgevoerd om het bodemprofiel te inventariseren en te controleren of de referentiedelen en de delen met onderwaterdrains vergelijkbaar zijn. De boringen zijn opgenomen in Bijlage 1. Aan een deel van de boorgaten zijn de verzadigde doorlatendheden bepaald met de boorgatenmethode. Met de gemeten doorlatendheden zijn de drainafstanden berekend waarbij nog voldoende water infiltreert om de verdamping door het gras bij te houden, zonder dat de grondwaterstanden te diep uitzakken. De meetresultaten en de berekeningen zijn opgenomen in Bijlage 2. De doorlatendheid van het veen bleek matig, waardoor een drainafstand van $4 \mathrm{~m}$ noodzakelijk was bij gebruik van drains met een inwendige diameter van $6 \mathrm{~cm}$.

\subsubsection{Primaire proeflocatie}

De inrichting van de primaire proeflocatie is aangegeven in Figuur 4. Perceel 5 en het zuidelijke deel van perceel 6 vormen samen met de sloot tussen de twee percelen de primaire proeflocatie. In de zuidelijke helft van de twee percelen zijn drains met een diameter van $6 \mathrm{~cm}$ aangebracht met een onderlinge afstand van $4 \mathrm{~m}$ op een diepte van ca. $70 \mathrm{~cm}$. Dit is ca. $20 \mathrm{~cm}$ onder het beoogde slootwaterpeil in de meetsloot tussen de twee percelen in. In verband met de bagger in de sloot zijn de eindpijpen van de drains verlengd met ca. 1,5 m drainpijp inclusief omhulling en afgedopt aan het einde. In verband met dit baggerprobleem wordt de sloot regelmatig gebaggerd met een baggerspuit. De middensloot is door middel van damwanden, bestaande uit een grote, stalen rijplaat, verdeeld in een noordelijke en een zuidelijke helft die gelegen is langs het referentiedeel zonder drains en respectievelijk langs het deel met drains. Tussen de twee slootdelen is een plek gecreëerd waar met behulp van een viertal pompen het slootwaterpeil in beide slootdelen op een constant peil wordt gehouden. De drooglegging is door de verschillende maaiveldhoogten niet overal hetzelfde. Bij perceel 5 is de drooglegging van het referentiedeel ca. $44 \mathrm{~cm}$ en van het perceeldeel met onderwaterdrains ca. $43 \mathrm{~cm}$. Bij perceel 6 is de drooglegging van het referentiedeel en van het perceeldeel met onderwaterdrains bijna gelijk en is ca. $49 \mathrm{~cm}$. Het verschil in drooglegging tussen perceel 5 en $6 \mathrm{komt}$ doordat perceel 6 ongeveer $5 \mathrm{~cm}$ hoger ligt dan perceel 5 . De hoeveelheden water die uit of in elk slootdeel worden gepompt, worden gemonitord. De aan- en afvoer gaat via een tweetal pvc-buizen die vanaf de meetsloot naar de brede sloot oostelijk van perceel 6 lopen. Deze brede sloot heeft het relatief hoge boezempeil, dat slecht 10 tot $20 \mathrm{~cm}$ onder het maaiveld van perceel 6 ligt. De percelen hebben in de lengterichting greppels, die zorg dragen voor een snelle oppervlakteafvoer via greppelbuizen. Om te voorkomen dat via de greppels water van het referentiedeel naar het draindeel stroomt of omgekeerd, zijn de greppels op de grenzen van de proefdelen dichtgemaakt. Per proefdeel zijn de greppels via een eigen greppelbuis verbonden met het bijbehorende deel van de meetsloot.

De volgende metingen worden uitgevoerd op de primaire proeflocatie:

1. Jaarlijks rond 1 maart de hoogte in $31 \mathrm{~m}$ lange lengteraaien over de grondwaterstandbuizen bij de referentie en het deel met onderwaterdrains;

2. Monitoring grondwaterstanden door middel van handmetingen en met Divers (perceel 5);

3. Monitoring slootpeilen met Divers en aflezen peilschalen;

4. Monitoring van de hoeveelheden ingelaten en uitgepompt water;

5. Monitoring neerslag met een regenmeter;

6. Metingen aan waterkwaliteit van het slootwater en bodemwater op perceel 5;

7. Beoordeling bedrijfsvoering uit metingen aan de draagkracht en een interview met dhr. Klaver;

8. Beoordeling geschiktheid voor weidevogels door middel van indringingsweerstandmetingen met een $1 \mathrm{~cm}^{2}$ conus en monitoring grashoogten en bloeimoment. 


\section{Inrichting primaire proeflocatie (percelen 5 en 6 )}

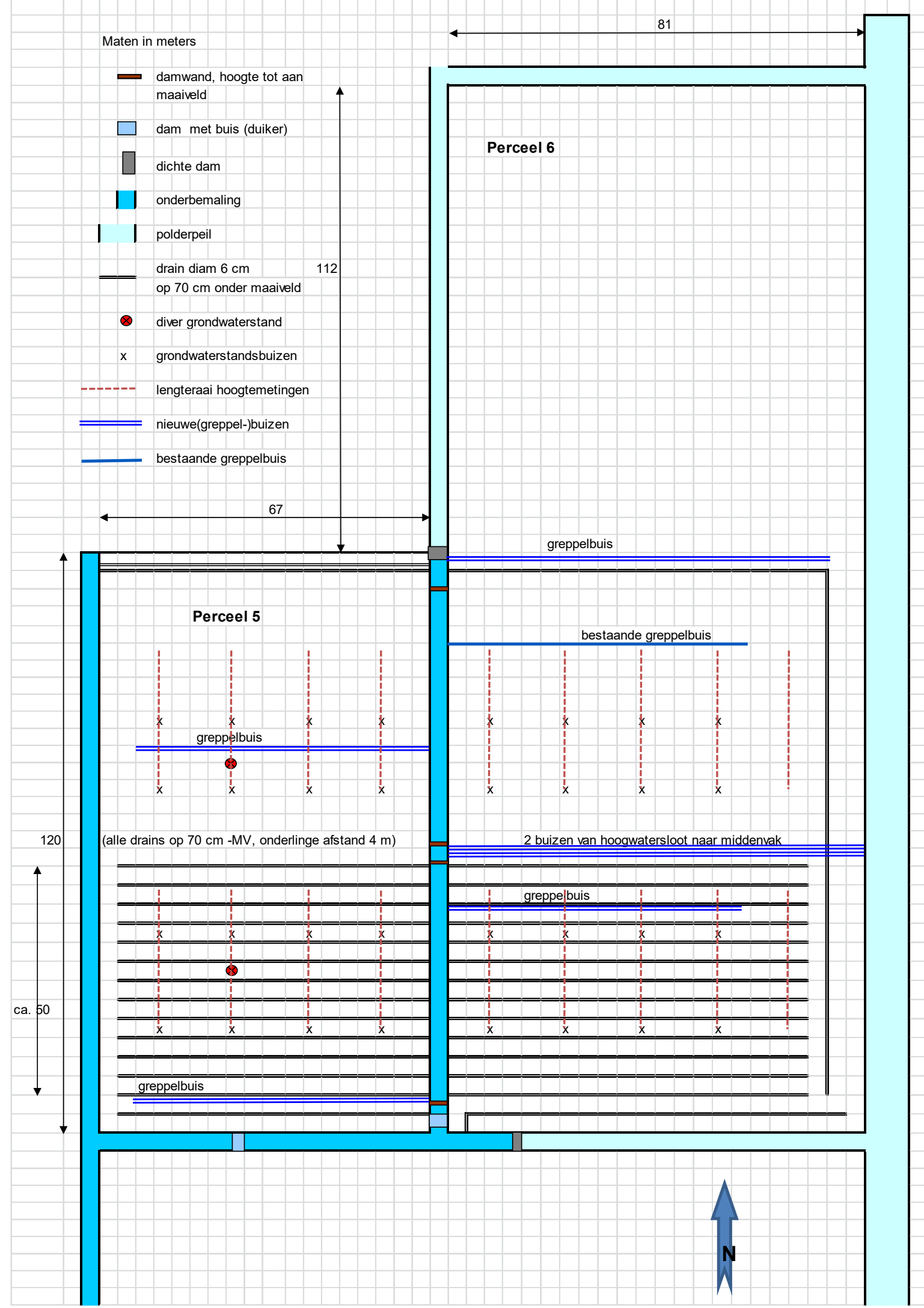

Figuur 4 Schets van de inrichting van de primaire locatie op de percelen 5 en 6. 


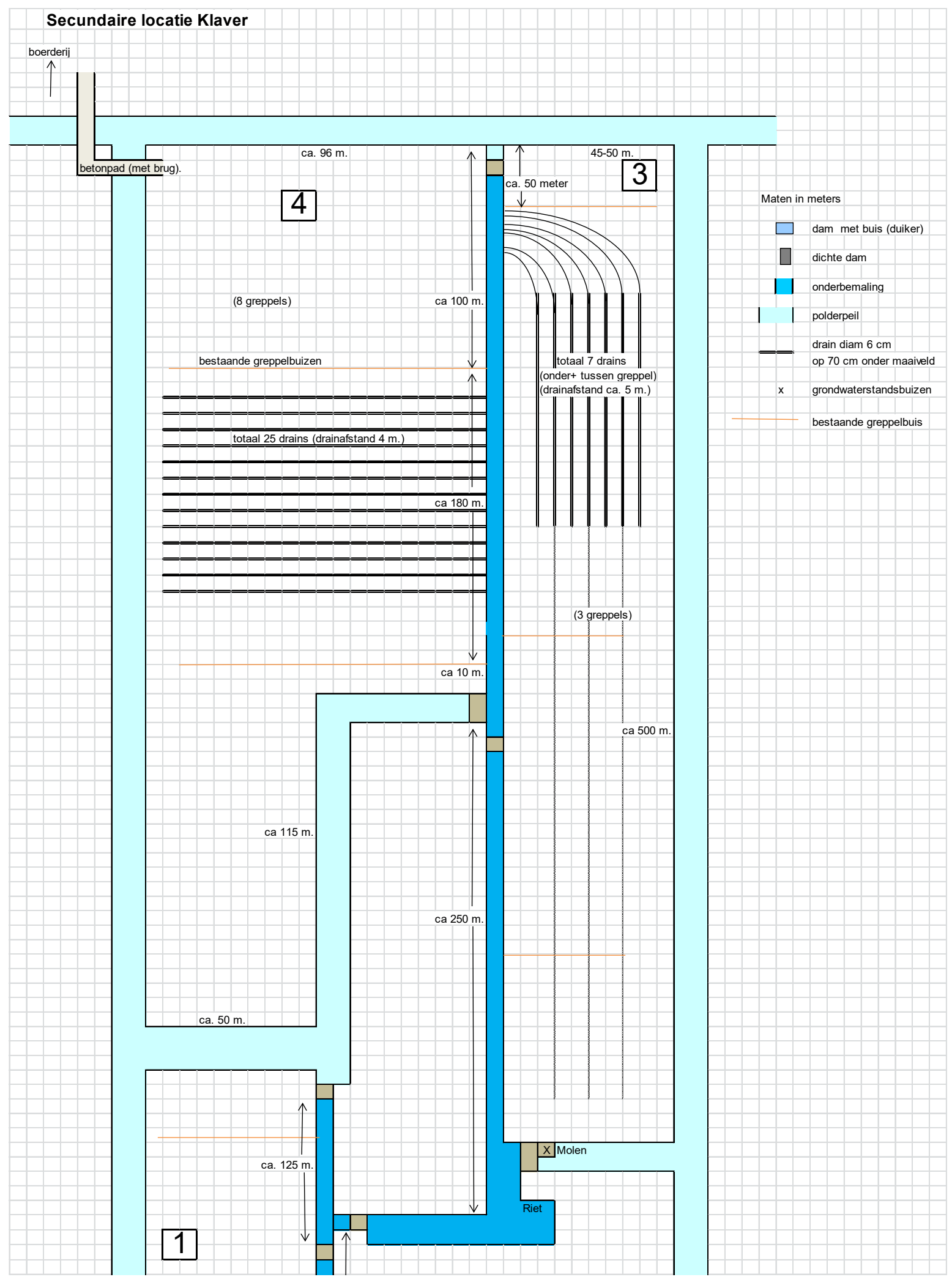

Figuur 5a Schets van de inrichting van de secundaire locatie op de percelen 3 en 4. 


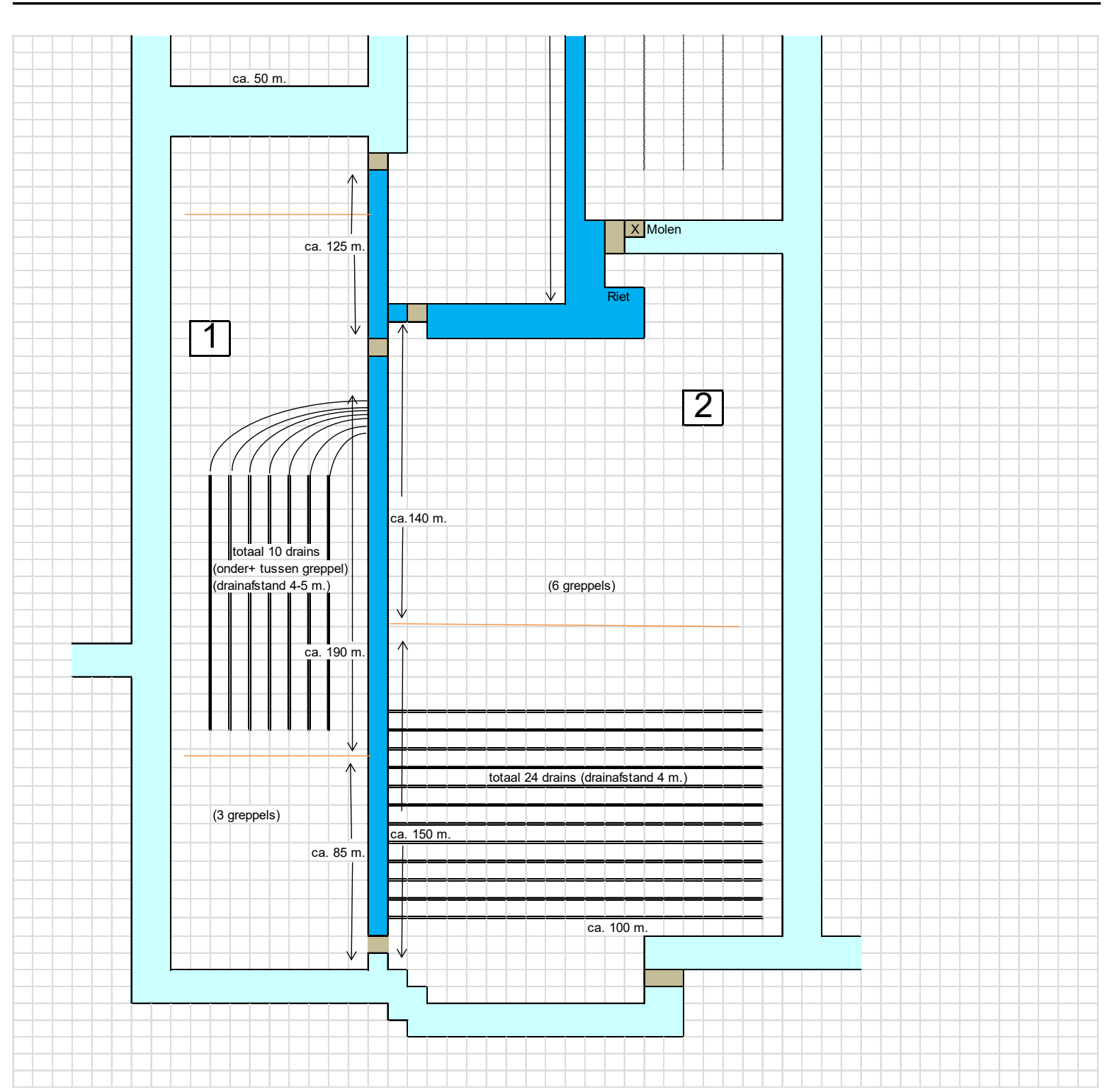

Figuur 5b Schets van de inrichting van de secundaire locatie op de percelen 1 en 2.

\subsubsection{Secundaire proeflocatie}

De secundaire proeflocatie is vooral bedoeld om te achterhalen of onderwaterdrains voordelen opleveren voor de bedrijfsvoering en om na te gaan wat de effecten kunnen zijn van onderwaterdrains op de omstandigheden voor weidevogels.

\subsubsection{Metingen}

\subsubsection{Maaivelddaling}

Bij perceel 5 is op de referentie een vast punt gemaakt naast de peilbuis met de diver, bestaande uit een stalen buis die tot op een draagkrachtige laag is geslagen.

Jaarlijks zijn in het vroege voorjaar rond 1 maart de hoogten gemeten op de primaire meetlocatie op de percelen 5 en 6 in lengteraaien van zuid naar noord. Deze raaien zijn aangegeven in Figuur 4 . Het nulpunt van de raaien is daarbij de zuidelijke grondwaterstandbuis. De raaien hebben een lengte van $31 \mathrm{~m}$ waarin beginnende op $1 \mathrm{~m}$, om de $2 \mathrm{~m}$ op 16 punten de hoogte wordt gemeten met behulp van een waterpasinstrument. 


\subsubsection{Grondwaterstanden en slootpeilen}

Bij de primaire proeflocatie zijn de grondwaterstanden op perceel 5 en slootpeilen gemonitord met een diver. Bij de primaire proeflocatie zijn per perceeldeel, met of zonder onderwaterdrains, acht freatische peilbuizen geplaatst die bij elk veldbezoek worden uitgelezen. Daarnaast wordt een diepe peilbuis geplaatst met een kort filter om de onderrandsituatie en de wegzijgsituatie in beeld te brengen.

Het oppervlaktewaterpeil in de sloot van het gedraineerde deel van de percelen 5 en 6 wordt gemonitord met een diver. Dezelfde niveaumeting vindt ook plaats in de sloot van het referentiedeel van beide percelen. In aanvulling daarop zijn eenvoudige peilschalen geplaatst die bij elk veldbezoek zijn afgelezen.

Bij elke voorjaarsronde (rond 1 maart) worden de hoogten van de peilbuizen ingemeten en gecontroleerd.

\subsubsection{Waterkwantiteit}

De aan- en afvoer worden alleen bij de primaire proeflocatie gemeten. Dit wordt gedaan voor het slootcompartiment van het gedraineerde deel van de percelen 5 en 6, alsook voor het slootcompartiment van het referentiedeel van beide percelen. Met behulp van in totaal vier watermeters en een logger wordt bijgehouden hoeveel water in en uit elk slootcompartiment wordt gepompt. De neerslag wordt met een geautomatiseerde regenmeter vastgelegd.

\subsubsection{Waterkwaliteit}

De waterkwaliteit is alleen in het oppervlaktewater en bodemwater van de primaire proeflocatie bemonsterd gedurende twee jaar, van juli 2013 tot oktober 2015.

\section{Oppervlaktewater}

Onderwaterdrains kunnen een effect hebben op de waterkwaliteit van de sloten waarin de drains uitkomen. In principe kan dit effect positief dan wel negatief zijn. Daar waar onderwaterdrains de oxidatie (afbraak) van het veen verminderen, is het denkbaar dat er minder nutriënten en bagger in de sloten terecht zal komen. Anderzijds zal door de onderwaterdrains de uitwisseling tussen bodemwater van de percelen en de sloot toenemen. Dit is immers het beoogde doel van de onderwaterdrains.

Voor de sloten is een intensieve bemonstering van de oppervlaktewaterkwaliteit uitgevoerd door een behulpzame vrijwilligster. In het slootcompartiment zonder en met onderwaterdrains zijn elke twee weken steeds op ongeveer $1 / 3^{e}$ van de compartimentlengte monsters genomen en bij elkaar gevoegd (mengmonster zonder drains van nr. 1-2-3 en mengmonster met drains van nr. 4-5-6). Ook het aanvoerwater is bemonsterd (nr. 7).

Aan de oppervlaktewatermonsters zijn de volgende bepalingen gedaan: $\mathrm{pH}$, alkaliniteit, kooldioxide, bicarbonaat, ortho-fosfaat, totaal-P, ammonium, nitraat, totaal- $\mathrm{N}$, calcium, magnesium, sulfaat, natrium, kalium, chloride, ijzer, mangaan, zink. Dit is het standaardanalysepakket van B-WARE.

\section{Bodemwater}

In het perceeldeel met drains is er bemonsterd op 10, 25 en $40 \mathrm{~m}$ afstand van de sloot (4 raaien); 2 raaien direct naast een drain ( $\mathrm{nr}$. 2-4-6, 8-10-12) en 2 raaien tussen 2 drains in (nr. 1-3-5, 7-9-11). In het perceeldeel zonder drains (de referentie) zijn ook 2 raaien bemonsterd op 10, 25 en $40 \mathrm{~m}$ afstand van de sloot (nr. 13-14-15, 16-17-18). De bemonstering van het bodemwater met behulp van poreuze cups heeft gedurende 2 jaar (2013-2015) tweemaal per jaar plaatsgevonden, aan het einde van de natte winterperiode en aan het einde van de droge zomerperiode.

Aan het poriewater zijn dezelfde bepalingen gedaan als aan het oppervlaktewater.

\section{Bodemmonsters}

Tevens zijn er eenmalig op alle meetpunten bodemmonsters verzameld om de bodemkarakteristieken van de veenbodem in de twee deelpercelen in beeld te brengen. Aan deze veenmonsters zijn de volgende parameters bepaald: Totaal-fosfor, totaal-calcium, totaal-ijzer, totaal-zwavel, totaalmagnesium, totaal- $N$, organische stofgehalte, totaal-mangaan, calciumgebonden- $P$, ijzergebonden- $P$ en organisch gebonden-P. 


\subsubsection{Bedrijfsvoering}

Naar verwachting leidt de aanleg van onderwaterdrains tot een toename van de draagkracht in het voorjaar, waardoor de agrariër eerder het land op kan. Om vast te stellen in welke mate de toepassing van onderwaterdrains voor de agrarische bedrijfsvoering voordelen biedt, worden in het vroege voorjaar elke 14 dagen de draagkracht gemeten met een penetrometer met een conus (punt) met een tophoek van $60^{\circ}$ en een basisoppervlakte van $5 \mathrm{~cm}^{2}$. De conus wordt tot de conusbasis of iets dieper in de zode gedrukt. De kracht die hiervoor nodig is gedeeld door de basisoppervlakte van de conus $\left(5 \mathrm{~cm}^{2}\right.$ ) geeft de indringweerstand en wordt uitgedrukt in $\mathrm{kgf} / \mathrm{cm}^{2}$ of MPa (MegaPascal). De piekwaarde is een kenwaarde voor de draagkracht van de grond voor berijding en vertrapping door koeien. Voor berijding ligt de grenswaarde voor de indringweerstand op 0,5 MPa $\left(5 \mathrm{kgf} / \mathrm{cm}^{2}\right)$ en voor vertrapping op 0,6 MPa (6 kgf/cm²) (Van Wijk, 1988; Beuving et al., 1989; Van den Akker et al., 1993).

Daarnaast wordt de eigenaar van de proefpercelen, de heer Klaver, geïnterviewd. Hem wordt gevraagd naar zijn ervaringen in de bedrijfsvoering en zijn bevindingen met de percelen met onderwaterdrains ten opzichte van de naastliggende referentiedelen zonder drains. De interviews zijn uitgevoerd door Karel van Houwelingen, verbonden aan de vroegere proefboerderij Zegveld en het huidige Veenweiden Innovatie Centrum (VIC).

\subsubsection{Geschiktheid voor weidevogels}

Het is belangrijk om het effect van de aanleg van onderwaterdrains op het voorkomen van weidevogels mee te nemen. Het tellen van weidevogels heeft weinig zin, omdat niet alleen de bodemgesteldheid, maar ook vele andere factoren het gedrag van weidevogels beïnvloeden. Daarom worden een aantal bodemparameters gemonitord die een relatie hebben met de geschiktheid van de percelen voor weidevogels. Een geschikte bodemparameter die een sterke relatie vertoont met het foerageersucces van weidevogels is de piek in de indringingsweerstand van een conus met een tophoek van $60^{\circ}$ en een basisoppervlakte van $1 \mathrm{~cm}^{2}$ over de $10 \mathrm{~cm}$ bovenlaag van de bodem (persoonlijke mededeling prof. dr. ir. David Kleijn, expert weidevogels, verbonden aan Wageningen UR). De metingen zijn eenvoudig te combineren met de metingen voor de indringingsweerstand met de conus van $5 \mathrm{~cm}^{2}$.

Als mogelijk probleem wordt gezien dat door de toepassing van onderwaterdrains het gras vroeger in het jaar gaat groeien en bloeien, waardoor het te hoog kan worden voor jonge kuikentjes van weidevogels. Door de vroege bloei kan de bijbehorende piek in het voorkomen van insecten - een belangrijke voedselbron voor de kuikens - ook te vroeg komen voor de kuikens, waardoor mogelijk voedselschaarste ontstaat. Om de verschillen in grasgroei tussen de referenties zonder drains en de perceeldelen met onderwaterdrains te monitoren, worden naast de indringweerstanden ook de grashoogten gemeten en het bloeimoment vastgesteld. 


\section{$3 \quad$ Resultaten en discussie}

\subsection{Maaivelddaling}

Jaarlijks zijn in het vroege voorjaar de hoogten gemeten op de primaire meetlocatie op de percelen 5 en 6 in lengteraaien van zuid naar noord (zie Figuur 4). In Figuur 6 en Tabel 2 zijn de resultaten gepresenteerd voor 2013, 2014 en 2015. Deze worden nog aangevuld met de resultaten van 2016. Op perceel 5 zijn de hoogten per perceeldeel op 4 raaien gemeten met elk 16 punten. De maaiveldhoogte in Figuur 6 en Tabel 2 is dus wat betreft perceel 5 het gemiddelde van 64 punten. Op perceel 6 zijn 5 raaien per perceeldeel gesitueerd met elk 16 punten. In 2016 bleek echter dat op perceel 6 bij het referentiedeel de raaien 4 en 5 waren verstoord. Ditzelfde gold voor raai 5 op het deel met drains. De verstoorde raaien zijn daarom verder buiten beschouwing gelaten. Perceel 6 blijkt ongeveer $5 \mathrm{~cm}$ hoger te liggen dan perceel 5 . Uit Figuur 6 blijkt uit de lineaire vergelijkingen dat de gemiddelde jaarlijkse maaivelddaling slechts 1 tot $2 \mathrm{~mm}$ per jaar is. In Tabel 2 zijn de gemiddelde hoogten en de maaivelddaling van 2013 tot 2016 gegeven. Daaruit volgt dat het referentiedeel van perceel 5 in 3 jaar slechts $1 \mathrm{~mm}$ zou zijn gezakt en het deel met drains zelfs helemaal niet zou zijn gezakt. Bij perceel 6 treden zelfs stijgingen op van respectievelijk 1 en $2 \mathrm{~mm}$. Al met al kan worden geconcludeerd dat het aantal meetjaren te beperkt is om goede uitspraken te doen over de grootte van de maaivelddaling en verschillen in maaiveldaling.

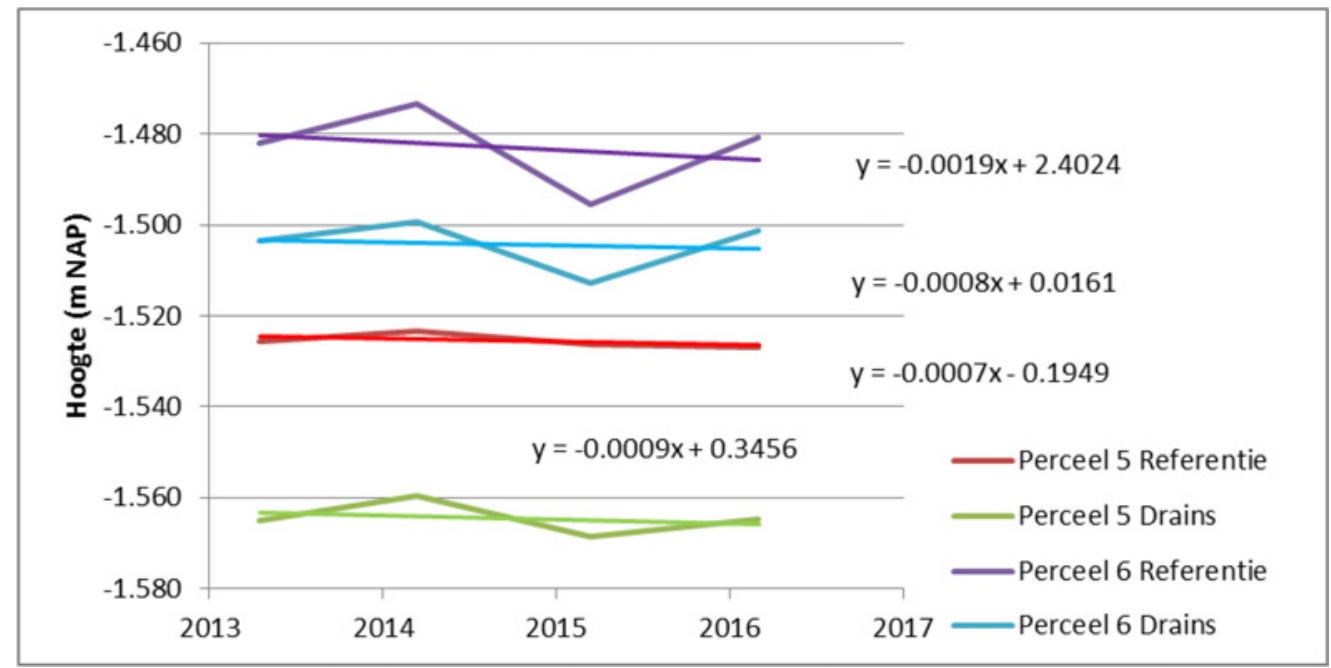

Figuur 6 Gemiddelde maaiveldhoogte in 2013, 2014, 2015 en 2016 van de referentiegedeelten en gedeelten met onderwaterdrains op de percelen 5 en 6. Gemiddelde waarden van de lengteraaien. Bij perceel 6 zijn bij de Referentie de raaien $1 \mathrm{t} / \mathrm{m} 3$ gemiddeld en bij de Drains de raaien $1 \mathrm{t} / \mathrm{m} 4$.

Tabel 2 Maaiveldhoogte in m NAP en maaivelddaling in mm in de periode 2013, 2014, 2015 en 2016.

\begin{tabular}{|c|c|c|c|c|c|c|c|c|}
\hline & \multicolumn{3}{|c|}{ Hoogte t.o.v. NAP (m) } & \multicolumn{5}{|c|}{ Maaivelddaling t.o.v. $2013(\mathrm{~mm})$} \\
\hline & $16-a p r-13$ & 13-mrt-14 & 13-mrt-15 & $1-\mathrm{mrt}-16$ & 16-apr-13 & $13-\mathrm{mrt}-14$ & 13-mrt-15 & $1-m r t-16$ \\
\hline Perceel 5 Referentie & -1.526 & -1.523 & -1.526 & -1.527 & 0 & 2 & -1 & -1 \\
\hline Perceel 5 Drains & -1.565 & -1.560 & -1.569 & -1.565 & 0 & 5 & -4 & 0 \\
\hline Perceel 6 Referentie & -1.482 & -1.473 & -1.496 & -1.481 & 0 & 9 & -13 & 1 \\
\hline Perceel 6 Drains & -1.504 & -1.499 & -1.513 & -1.501 & 0 & 4 & -9 & 2 \\
\hline
\end{tabular}




\subsection{Grondwaterstanden en slootpeilen}

De resultaten van de continumetingen aan de grondwaterstanden en slootpeilen op perceel 5 zijn weergegeven in Figuur 7. De metingen zijn begin april 2013 begonnen en half oktober 2015 geëindigd. Op deze wijze is er gedurende drie zomerperioden en twee winterperioden gemeten. De meetresultaten waren bij de continumeting op het referentiedeel tussen 20 oktober 2014 en 5 december 2014 niet betrouwbaar en zijn in Figuur 7 weggelaten. Daarnaast zijn op de percelen 5 en 6 in 2013 en 2014 per perceeldeel met of zonder drains tweewekelijks de grondwaterstanden in 8 peilbuizen met de hand gemeten. De resultaten van perceel 5 zijn in Figuur 7 en 8 en van perceel 6 in Figuur 9 gepresenteerd.

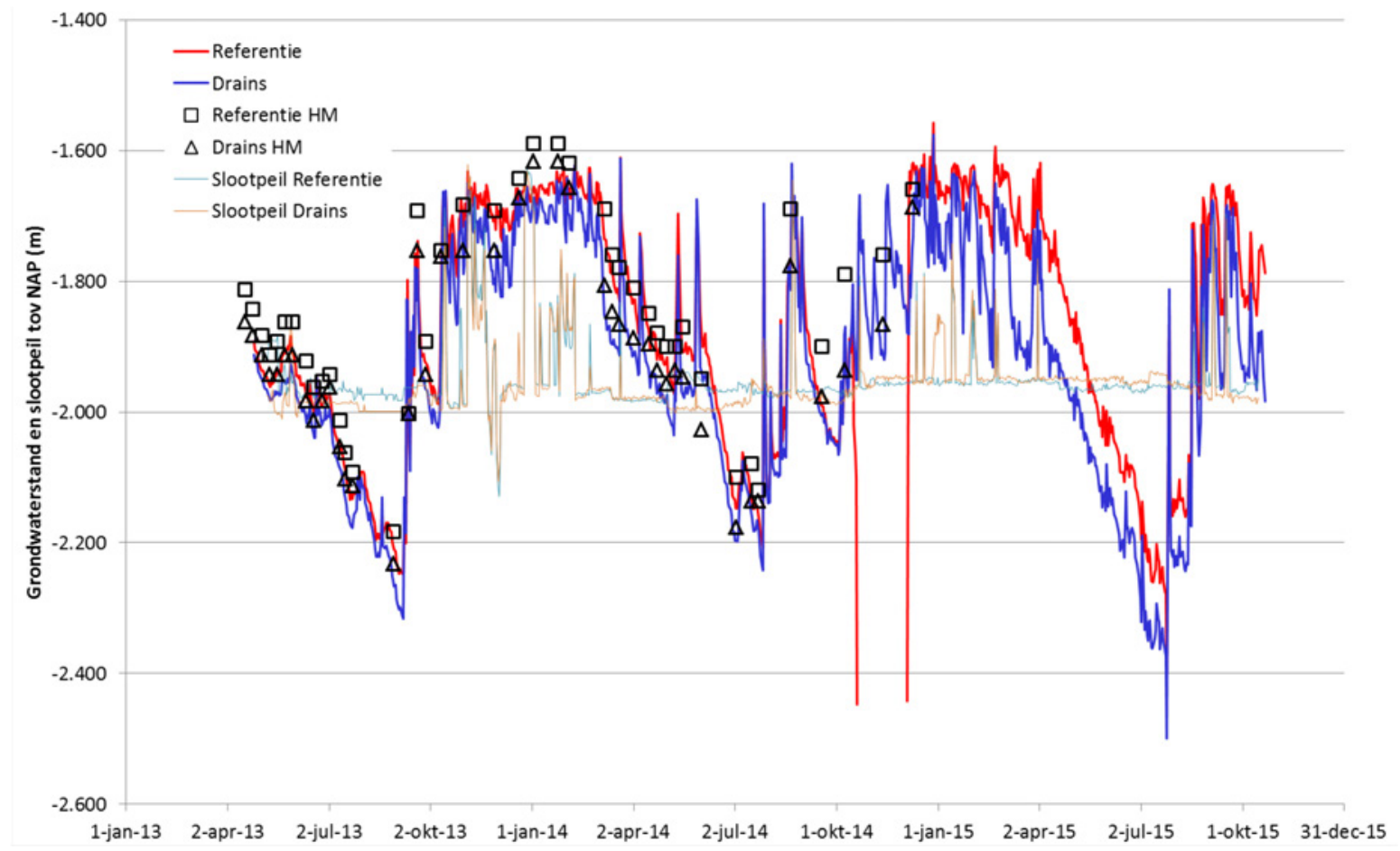

Figuur $7 \quad$ Grondwaterstanden op perceel 5 gemeten met drukopnemers en loggers en handmatig (HM, gemiddelde van 8 peilbuizen) en slootpeilen.

Wat betreft de slootpeilen valt op dat er vrij grote schommelingen optreden, vooral in de natte perioden. In deze perioden moet er water worden uitgepompt. Bij veel regen in een korte periode komt veel water van het perceel via de greppels en greppelbuizen in korte tijd in de sloot en kan de pomp deze toevoer niet tijdig afvoeren, waardoor het slootpeil stijgt. Op zich is dit geen probleem of onrealistisch, want ook in een gewone sloot zal de afvoer niet altijd de aanvoer bij kunnen houden. Echter, in de meetsloot werden - ondanks frequent baggeren en schonen - de doorvoer en pompcapaciteit af en toe sterk beperkt door bagger en vuil. De bagger en vuil verstoorden daarnaast ook soms het regelsysteem, waardoor het slootpeil verkeerd werd ingesteld. In perioden met toevoer waren de problemen in het algemeen gering.

De resultaten in de Figuren 7, 8 en 9 laten zien dat de grondwaterstanden in de perceeldelen met onderwaterdrains in natte perioden lagere grondwaterstanden hebben. De drainerende functie van de onderwaterdrains lijkt goed te voldoen. De infiltrerende functie lijkt echter tegen te vallen. De continumetingen op perceel 5, gepresenteerd in Figuur 7, laten zien dat in 2013 de grondwaterstand bij de drains ca. $5 \mathrm{~cm}$ dieper uitzakt dan bij de het referentieperceel. In 2015 is dit zelfs ca. $10 \mathrm{~cm}$. Het lijkt erop dat de grondwaterstanddaling in het voorjaar door de drainerende werking niet wordt goedgemaakt door infiltratie in de zomerperiode. De handmetingen in raaien in dwarsrichting van het perceel, gepresenteerd in Figuur 8 en 9, bevestigen dit beeld grotendeels, maar niet helemaal. Het blijkt namelijk dat er nog grote verschillen per dwarsraai kunnen zijn. Bij de perceeldelen met drains is 
bij perceel 5 de grondwaterstand in de noordelijke dwarsraai duidelijk hoger dan in de zuidelijke dwarsraai. Bij perceel 6 heeft bij de drains juist de zuidelijke dwarsraai een duidelijk hogere grondwaterstand. Dit lijkt erop te duiden dat er drains zijn die goed tot matig infiltreren en andere die duidelijk slechter functioneren. Het beeld blijft echter onduidelijk, want het blijkt dat de verschillen in grondwaterstand bij de referentiedelen in dezelfde ordegrootte liggen als bij de draingedeelten.

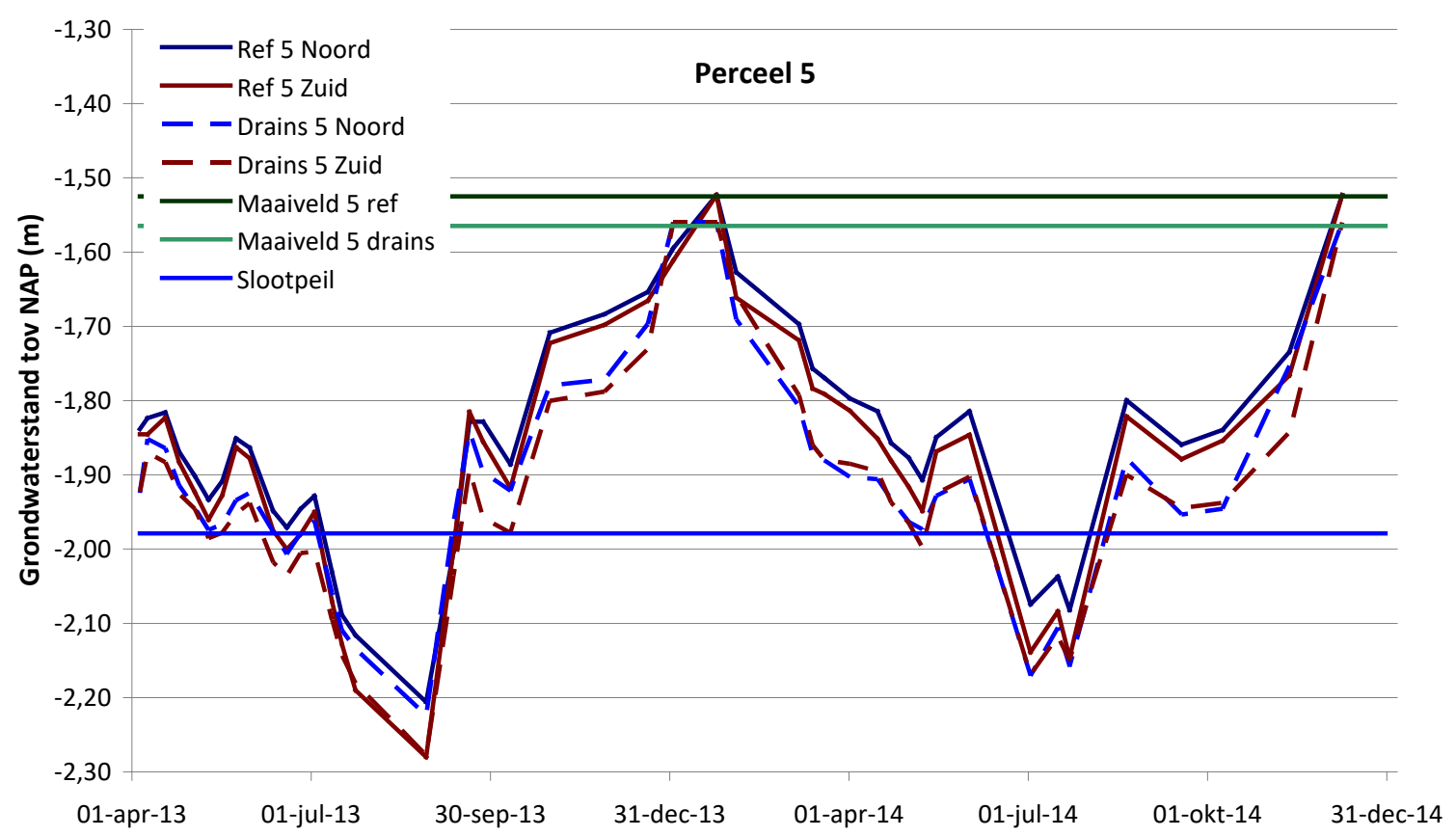

Figur $8 \quad$ Gemiddelde grondwaterstanden elke twee weken handmatig gemeten in peilbuizen in raaien van 4 buizen op perceel 5. Per perceeldeel (referentie en met drains) in een noordelijke en een zuidelijke raai.

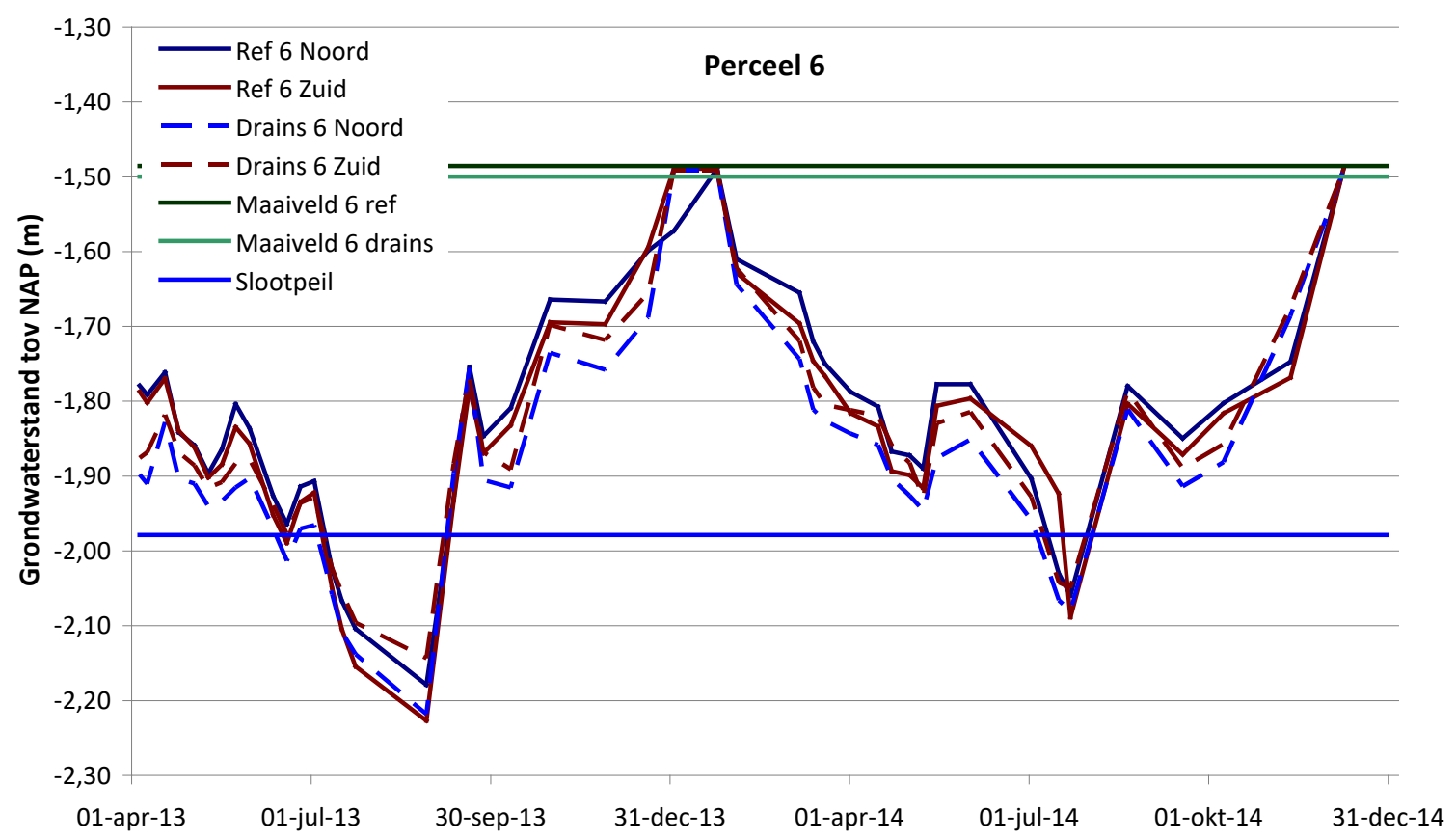

Figur 9 Gemiddelde grondwaterstanden elke twee weken handmatig gemeten in peilbuizen in raaien van 4 buizen op perceel 6. Per perceeldeel (referentie en met drains) in een noordelijke en een zuidelijke raai. 


\subsection{Waterkwantiteit: debieten}

Met debieten wordt bedoeld de hoeveelheden water die in en uit de compartimenten van de sloot worden gepompt. Een overzicht van de debieten in de meetperiode van mei 2013 tot oktober 2015 wordt gepresenteerd in Figuur 10. In de bovenste figuur zijn de gemeten hoeveelheden in $\mathrm{m}^{3}$ gegeven. Daarbij is gecorrigeerd voor schommelingen in het slootpeil, die gedurende een korte tijd een berging van maximaal enkele tientallen $\mathrm{m}^{3}$ kunnen veroorzaken. Een vergelijking van het referentiedeel en het deel met onderwaterdrains is op basis van $\mathrm{m}^{3}$ op deze wijze echter niet goed mogelijk omdat de drains een uitwerking hebben over bijna het gehele perceeldeel, terwijl van het referentiedeel slechts ongeveer de helft via de bodem door de middensloot wordt beïnvloed. Daarom zijn de debieten naar rato van de respectievelijk betrokken oppervlakten omgerekend naar mm (zie onderste figuur in Figuur 10). Op deze wijze kan ook beter worden vergeleken met de neerslag en gewasverdamping, die ook in $\mathrm{mm}$ worden uitgedrukt. Een complicerende factor is nog wel dat bij zowel het referentiedeel als het deel met drains alle greppels per deel via greppelbuizen uitkomen op het aangrenzende compartiment van de meetsloot. Voor het referentiedeel houdt dit in dat er in natte perioden met een hoge grondwaterstand en veel neerslag - waardoor er veel afvoer via de greppels plaatsvindt - de afvoer uitgedrukt in $\mathrm{mm}$ ongeveer de helft lager is dan in de onderste figuur in Figuur 10 wordt aangegeven.
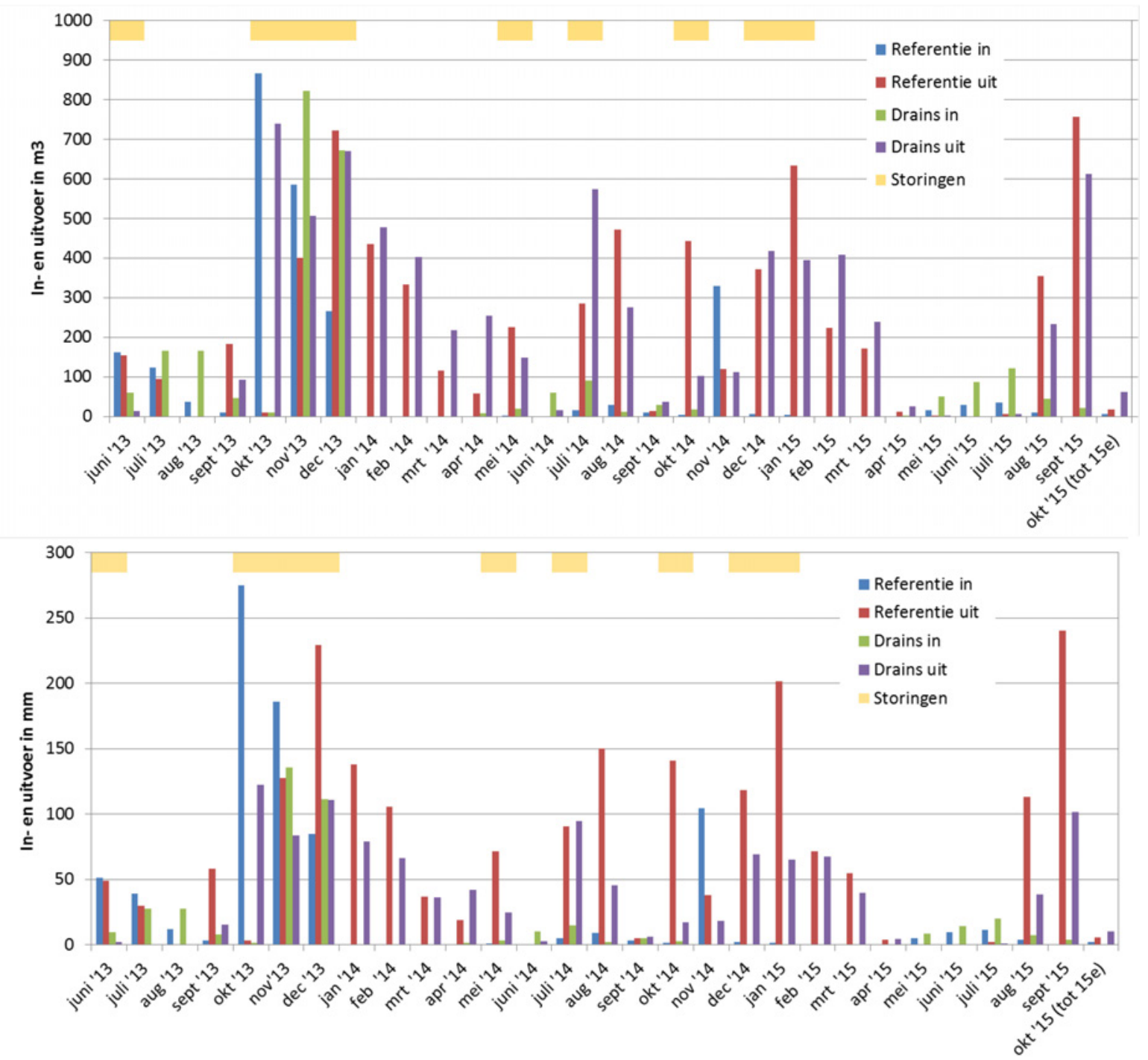

Figuur 10 Hoeveelheden water in $\mathrm{m}^{3}$ (bovenste figuur) en omgerekend naar mm (onderste figuur) die per maand zijn in- en uitgepompt. Met oranje blokken boven in de figuur is aangegeven of er storingen zijn opgetreden die de meetresultaten kunnen beïnvloeden. 


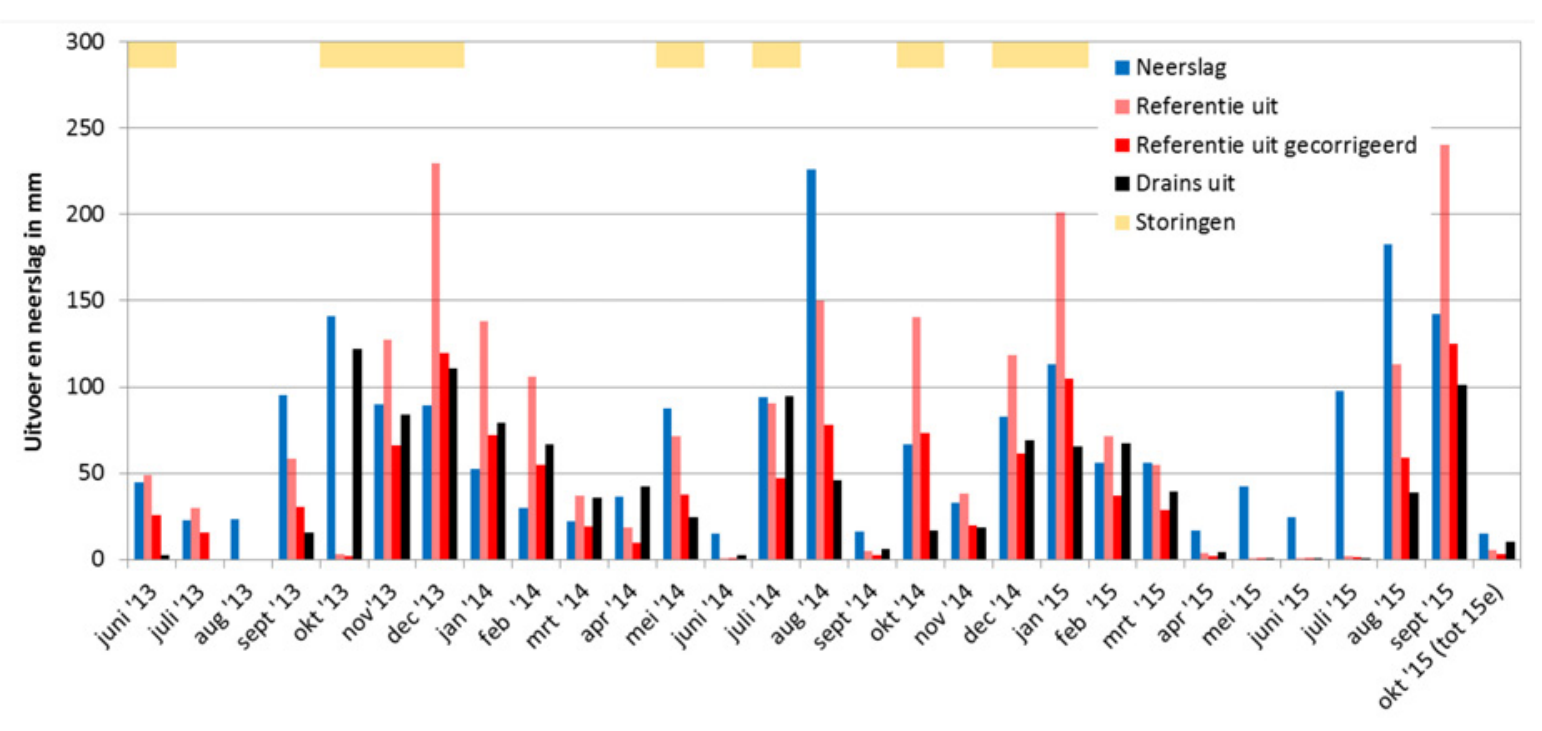

Figuur 11 Neerslag per maand in $\mathrm{mm}$ en hoeveelheden water die per maand zijn uitgepompt, omgerekend naar $\mathrm{mm}$. In natte perioden met hoge grondwaterstanden wordt de afvoer van de referentie grotendeels bepaald door greppelafvoer en moeten de gecorrigeerde (rode) waarden worden gebruikt.

Door ervan uit te gaan dat in dergelijke perioden het overgrote deel van de neerslag via de greppels en greppelbuizen in de sloot terechtkomt, kunnen de afvoerwaarden voor de referentie in Figuur 10 worden gecorrigeerd. In plaats van de hoeveelheden water in liters te delen door het halve oppervlakte van de referentiedelen $\left(3150 \mathrm{~m}^{2}\right)$, moet het aantal liters dan worden gedeeld door de oppervlakte die afvoert naar de greppels $\left(6050 \mathrm{~m}^{2}\right)$. In Figuur 11 zijn deze gecorrigeerde waarden gegeven in $\mathrm{mm}$ water die per maand uit het slootcompartiment van de referentie worden gepompt (rode staven). Die gecorrigeerde waarden gelden dus alleen voor natte perioden met veel neerslag. In het algemeen zijn dit de wintermaanden en de grondwaterstanden in de Figuren 7, 8 en 9 laten zien dat tot in maart de grondwaterstanden in de referentiepercelen slechts 10 tot $20 \mathrm{~cm}$ onder maaiveld liggen en de grond weinig bergingscapaciteit heeft. Dan gelden vooral de gecorrigeerde waarden voor de uitvoer. Deze blijken in januari en februari 2014 ongeveer gelijk en in januari 2015 groter te zijn dan de uitvoer bij de drains. Daarna volgt in beide jaren een paar maanden waarin bij de drains meer wordt afgevoerd dan bij de referentie. We zien dan ook de grondwaterstand bij de perceeldelen met drains meer dalen dan bij de referentie (zie Figuren 7, 8 en 9). Het algemene beeld is dat in natte perioden bij de referentiedelen een groter deel van de neerslag via oppervlakteafvoer wordt afgevoerd naar de sloot dan bij de delen met drains. Gedurende de wintermaanden en begin van het voorjaar voeren de drains een groot deel van de neerslag vertraagd af naar de sloot. Bij de drains gaat dus een groter deel van de neerslag via tussenberging in de grond naar de sloot dan bij het referentiedeel. Hierdoor zullen bij de drains minder meststoffen afspoelen richting sloot en komt een groter deel van de meststoffen in de grond en zo beschikbaar voor het gras, waardoor de nutriëntenefficiëntie toeneemt.

Als een nadeel van onderwaterdrains wordt in het algemeen gezien dat deze het watersysteem versnellen, zodat bij zeer grote hoeveelheden neerslag in korte tijd een veel groter deel van de neerslag extra snel in het slotensysteem terechtkomt, wat leidt tot hogere slootpeilen en een mogelijk tekort aan gemaalcapaciteit van de polder en overstromingsgevaar. We zullen deze algemene zienswijze toetsen aan de hand van enkele hevige en grote regenbuien aangegeven in Figuur 12 . In de aangegeven periode van 10 juni tot 28 september is op 28 juli $54 \mathrm{~mm}$ en rond 22 augustus 2014 in twee dagen bijna $100 \mathrm{~mm}$ regen gevallen. Uit Figuur 12 blijkt dat op 28 juli het slootpeil bij de referentie stijgt met $15 \mathrm{~cm}$ en bij de drains met $16 \mathrm{~cm}$. De piek in de sloten wordt voor een deel bepaald door de neerslag die op het wateroppervlak valt. Verder blijkt dat het grootste deel van de neerslag infiltreert in de bodem. De grondwaterstand, die voor de regenbui bij zowel de referentie als de drains op ca $65 \mathrm{~cm}-\mathrm{mv}$ en daarmee $20 \mathrm{~cm}$ onder het slootpeil stond, stijgt dan snel tot $20 \mathrm{~cm}-\mathrm{mv}$ en zakt binnen enkele dagen naar $55 \mathrm{~cm}-\mathrm{mv}$. Dit is onder het slootpeil. Dit duidt erop dat het droge veen als een spons het water vertraagd heeft opgezogen. In dit geval kan men ervan uitgaan dat de neerslag slechts voor een beperkt deel via de greppels en greppelbuizen in de sloot terechtkomt. De ongecorrigeerde uitvoer voor de referentie kan dan worden gebruikt (rood gestreepte lijn). 


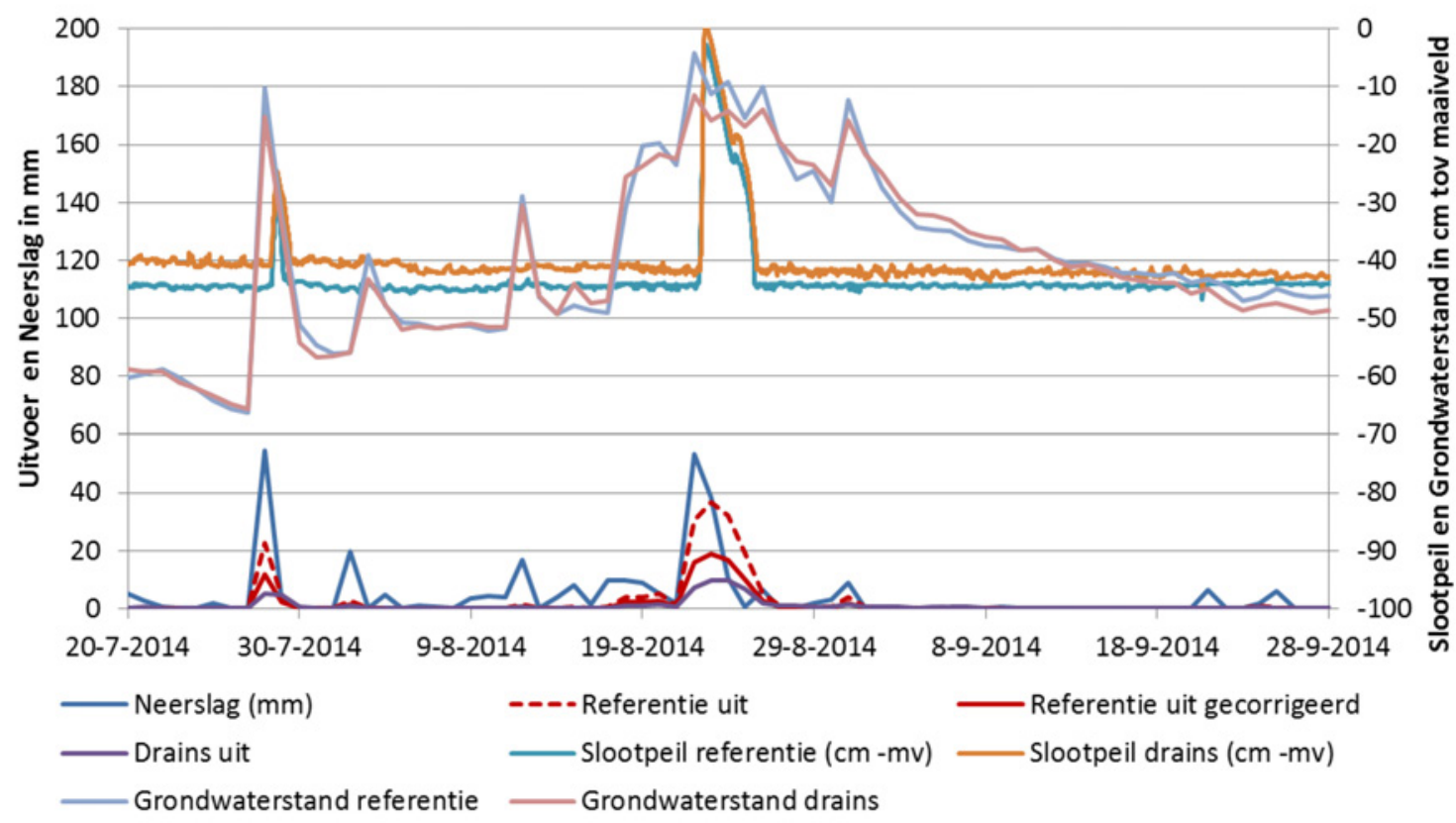

Figuur 12 Neerslag per dag in $\mathrm{mm}$ en hoeveelheden water die per dag zijn uitgepompt, omgerekend naar $\mathrm{mm}$. In natte perioden met hoge grondwaterstanden wordt de afvoer van de referentie grotendeels bepaald door greppelafvoer en moeten de gecorrigeerde (rode) waarden worden gebruikt.

Rond 22 augustus is de situatie heel anders. Door een aantal regenbuien voorafgaand aan 22 augustus is de grondwaterstand gestegen tot ca. $20 \mathrm{~cm}-\mathrm{mv}$. Vervolgens valt in twee dagen bijna $100 \mathrm{~mm}$ neerslag. Daardoor worden zowel de grond als de sloten bijna volledig gevuld, waarbij het slootpeil bij de referentie met $41 \mathrm{~cm}$ en bij de drains met $43 \mathrm{~cm}$ stijgt. (NB Daardoor kan ook een deel van het water over de damwanden zijn gelopen en door de buis in de zuidelijke dam en de doorgetrokken drains langs de noordelijke rand van perceel 5. De capaciteit van de buis in de dam en de drains is echter beperkt, temeer daar ook in de sloot waar het water naartoe stroomt het slootpeil naar verwachting zeer hoog zal hebben gestaan.) Door de hevige regenbui stijgt de grondwaterstand bij de referentie ca. $5 \mathrm{~cm}$ meer dan bij het deel met de drains. In deze situatie kan ervan uit worden gegaan dat greppels en greppelbuizen het grootste deel van het water naar de sloot afvoeren. Daarom kan in deze situatie voor de referentie de lijn voor de gecorrigeerde uitvoer (rode lijn in Figuur 12) worden gebruikt. Vervolgens volgt een periode waarin de grondwaterstand langzaam zakt richting slootpeil. Daarbij zorgen twee natte dagen eind augustus nog voor een kortstondige stijging van de grondwaterstand. Al met al blijkt dat de berging in de bodem een groot deel van de hevige regenbui opneemt. Bij de referentie moet gedurende de eerste twee dagen na de hevige regenbui bijna tweemaal zo veel water worden afgevoerd als bij de perceeldelen met drains. Het blijkt dat de algemene zienswijze dat onderwaterdrains het watersysteem versnellen, moet worden genuanceerd: er moet ook rekening worden gehouden met de oppervlakte- en greppelafvoer en het bergingsvermogen van de bodem op het moment dat de bui valt.

In Figuur 13 zijn de hoeveelheden water in $\mathrm{mm}$ gegeven die in de slootcompartimenten zijn gepompt. Een deel van dit water vult het slootwater aan dat direct aan het wateroppervlak is verdampt, maar het grootste deel zal in de aangrenzende percelen infiltreren. Bij de referentie infiltreert het slootwater via de slootwand en bij het perceeldeel met onderwaterdrains grotendeels via de drains. Bij de referentie zal het infiltrerende water zich verdelen over ongeveer de helft van het perceel grenzend aan de sloot en bij de perceeldelen met onderwaterdrains over bijna de gehele perceelbreedte. Een deel van het geïnfiltreerde water zal via wegzijging naar het diepere grondwater verdwijnen, maar het grootste deel zal dienen om de evapotranspiratie van het gras te compenseren. Daarom is in Figuur 13 ook het neerslagtekort in $\mathrm{mm}$ aangegeven. Er zal pas water in de percelen infiltreren indien de grondwaterstand lager is dan het slootpeil. In het algemeen is dit pas eind mei of begin juni (zie Figuur 7, 8 en 9). Het blijkt dat het neerslagtekort in mei en in de droge zomermaanden in het algemeen veel groter is dan de hoeveelheden water die vanuit de slootcompartimenten in het perceel infiltreren. De grond zal daarom bij zowel de referentie als de drains uitdrogen en de grondwaterstand zal verder dalen tot 20 tot $35 \mathrm{~cm}$ onder het slootpeil. 


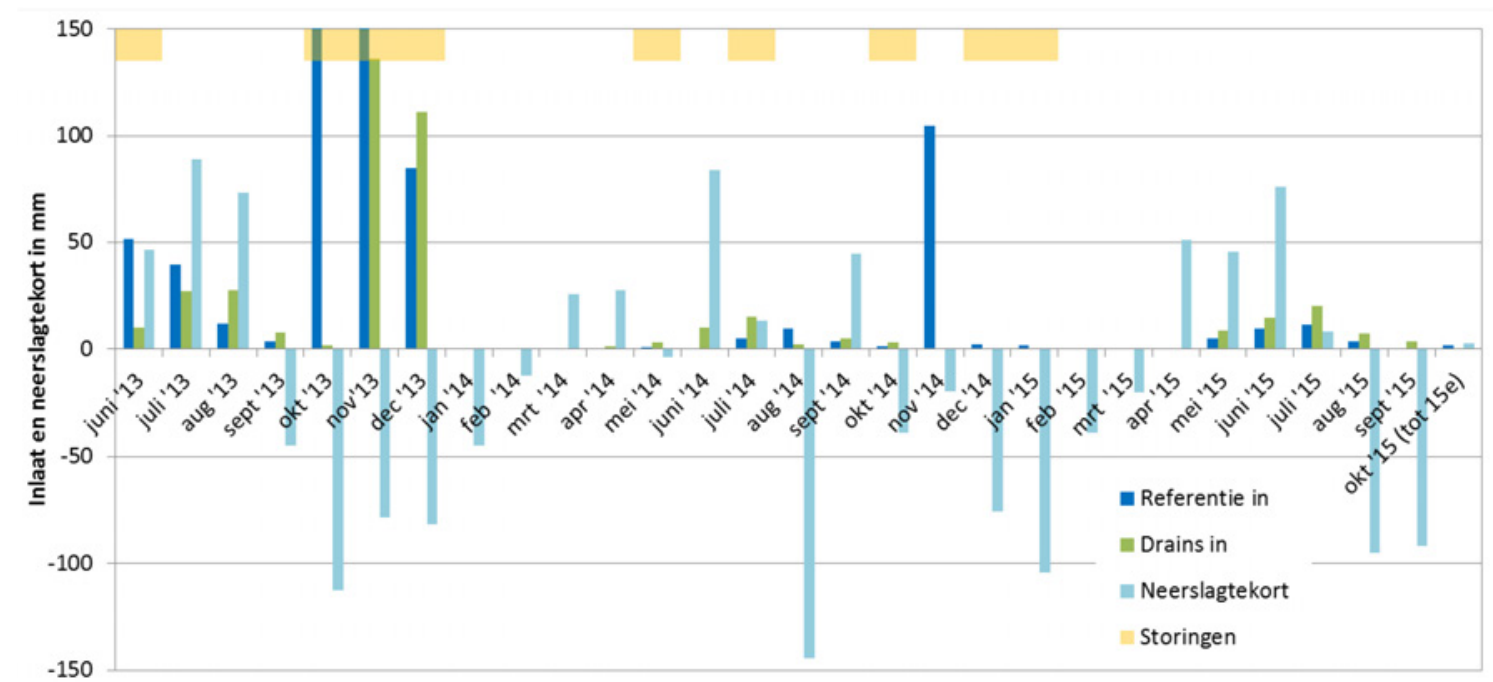

Figuur 13 Neerslagtekort per dag in $\mathrm{mm}$ en hoeveelheden water die per dag zijn ingepompt, omgerekend naar $\mathrm{mm}$.

Hoewel via de drains twee- tot driemaal zoveel water infiltreert als bij de referentie, blijken de grondwaterstanden bij de drains toch enkele centimeters dieper onder het slootpeil uit te zakken dan bij de referentie. Blijkbaar kan ook de infiltratie via de drains de grasverdamping niet bijhouden. Dit blijkt ook uit een nadere beschouwing van een droge periode ( 1 augustus tot 4 september 2013) in Figuur 14. De verdamping van het gras is ongeveer driemaal de hoeveelheid water dat via de drains infiltreert. Per drain blijkt er per dag ongeveer 240 liter water te infiltreren. Volgens de berekening van de infiltratie en drainafstanden in Bijlage 2 zou bij een verschil tussen slootpeil en grondwaterstand van $25 \mathrm{~cm}$ de infiltratie ca $3 \mathrm{~mm} / \mathrm{dag}$ zijn. Eind augustus 2014 ligt de grondwaterstand ongeveer $25 \mathrm{~cm}$ onder het slootpeil, maar is de infiltratie via de drains slechts ca. $1 \mathrm{~mm} / \mathrm{dag}$, dus $1 / 3^{\mathrm{e}}$ van de berekende infiltratie. Een nadere beschouwing van de drainerende werking van de drains leert dat in een periode met weinig neerslag, maar wel een grondwaterstand die ca $25 \mathrm{~cm}$ boven het slootpeil ligt, de hoeveelheid uit te pompen water ca. $1 \mathrm{~mm} / \mathrm{dag}$ is. De infiltrerende en drainerende werking van de onderwaterdrains is dus slechter dan verwacht. De belangrijkste oorzaak hiervan is waarschijnlijk de bagger in de sloot. Hoewel de sloot regelmatig wordt uitgebaggerd, blijft de sloot steeds dichtslibben met bagger. De oevers van de sloot blijken zeer kwetsbaar te zijn en kalven gemakkelijk af of schuiven in zijn geheel af in de sloot. Om te zorgen dat er geen bagger in de drains loopt, zijn de eindbuizen daarom verlengd met ca. 1,5 m drainagebuis met omhulling en aan het einde afgedopt. In de polder Zeevang (Hoving et al., 2015) zijn hier goede ervaringen mee opgedaan, maar de baggervorming in onze proeflocatie is duidelijk extremer dan in de polder Zeevang.

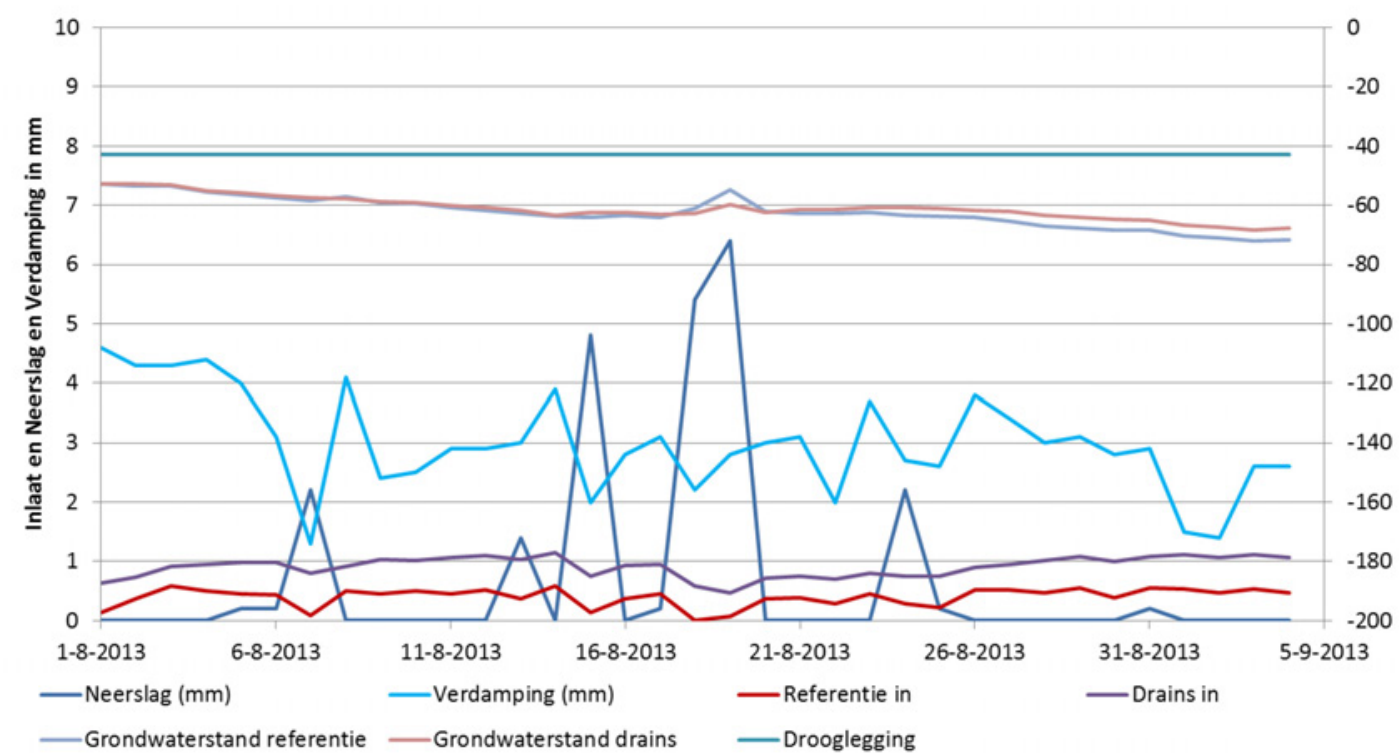

Figuur 14 Infiltratie, neerslag en verdamping in $\mathrm{mm}$ in een droge periode 2013. 


\section{$3.4 \quad$ Waterkwaliteit}

De water- en bodemwaterkwaliteit zijn potentieel belangrijke indicatoren voor het bepalen van het effect van onderwaterdrains (OWD) op de oxidatie van veen. Het effect van OWD is waarschijnlijk veel sneller meetbaar in de verandering van de kwaliteit van het poriewater dan dat er sprake is van een meetbaar effect op de maaivelddaling (vaak pas na 5-10 jaar betrouwbaar meetbaar). Als door de verhoging van de grondwaterstanden in de zomer, als gevolg van OWD, de oxidatie in het veen afneemt, leidt dit naar verwachting ook tot een verbetering van de waterkwaliteit van het grondwater en daarmee ook van het oppervlaktewater. Tegelijkertijd is de oxidatie van veen ook weer afhankelijk van de kwaliteit van het oppervlaktewater dat via de drains in het veen wordt gebracht. Daarom is in 2014 en 2015 een monitoring van grondwater en oppervlaktewater in een proefperceel met OWD uitgevoerd door onderzoekcentrum B-Ware.

Het onderzoek van de waterkwaliteit is uitgevoerd door B-Ware en is in een apart rapport beschreven. Dit rapport is als Bijlage 4 toegevoegd. In deze paragraaf worden de resultaten uit het rapport van B-Ware samengevat.

\subsubsection{Bodemkarakteristieken onderzoek perceel}

Uit een bemonstering van de toplaag blijkt dat het referentiedeel (REF) van het proefperceel, dus zonder OWD, wat afwijkende bodemeigenschappen heeft ten opzichte van het deel van het proefperceel met OWD. De totaal-Fe en totaal-P gehaltes in REF zijn structureel wat lager dan in het deel met OWD, de Fe:P-ratio's op beide deelpercelen zijn echter wel vergelijkbaar. De totale hoeveelheid $S$ in de bodem lijkt juist wat hoger in REF, waardoor de Fe:S-ratio's in REF wat lager zijn. De Fe:S-ratio is bij zowel REF als OWD veel lager dan 1, wat betekent dat in deze bodems onder natte omstandigheden het overgrote deel van het aanwezige ijzer gebonden is aan gereduceerd zwavel. De meer zuurstofrijke omstandigheden aan de zijkanten van de sloot langs het perceel leiden waarschijnlijk tot een verhoogde afbraak van het veen (afname OS) en een verhoogde mineralisatie en inklinking van het veen door veenoxidatie die leiden tot relatief hogere gehalten van o.a. $\mathrm{P}, \mathrm{S}$ en $\mathrm{Fe}$ in de oeverbodem. De oxidatieprocessen zijn netto ook verzurend, waardoor calcium (Ca) en magnesium ( $\mathrm{Mg}$ ) kunnen uitspoelen uit de toplaag. Dit is te zien aan de lagere Ca-concentratie in de bodem en de hogere $(\mathrm{Ca}+\mathrm{Mg})$ : Al-ratio in de bodem op een halve meter uit de sloot.

\subsubsection{Effecten OWD op de grondwater kwaliteit}

Gedurende 2 jaar is het grondwater op $70 \mathrm{~cm}$ diepte in de veenbodem bemonsterd en geanalyseerd net na de winterperiode (OWD in perceel: afvoerfunctie) en aan het einde van de zomerperiode (OWD in perceel: aanvoerfunctie of eventueel afvoerfunctie in natte periodes). De Cl-concentraties in het grondwater tussen de drains zijn jaarrond fors hoger dan de concentraties net naast de drains. Als de drains afvoeren in natte perioden nemen de $\mathrm{Cl}$-concentraties bij de drain toe. In droge perioden in de zomer infiltreert juist slootwater en is het omgekeerde patroon te zien. Uit de $\mathrm{Cl}$-concentraties volgt dat bij de percelen met onderwaterdrains deze infiltratie veel hoger is dan bij het referentiedeel zonder OWD. De Cl-concentraties in het slootwater (ook in het inlaatwater) zijn in deze periodes veel lager (ca. $15.000 \mu \mathrm{mol} / \mathrm{L}$ ) dan in de percelen (in het midden van REF meer dan $40.000 \mu \mathrm{mol} / \mathrm{L}$ ). Verder blijkt dat in het grondwater van de percelen de $\mathrm{P}-$, ammonium- (NH4), Ca- en Mg-concentratie sterk gecorreleerd zijn met de $\mathrm{Cl}$-concentratie (Figuur 15). Terwijl de $\mathrm{Cl}$-concentratie in het grondwater direct naast de drains gemeten bij raai 1 netjes meeloopt met de concentraties in de sloot en drainbuis, is dit bij raai 2 in veel mindere mate het geval. Dit zou kunnen betekenen dat de (in ieder geval infiltrerende) werking van de drain bij raai 2 veel minder goed was gedurende het onderzoek. De effecten van OWD in dit onderzoek worden daarom vooral gebaseerd op de uitkomsten van raai 1 en niet van raai 2 . 

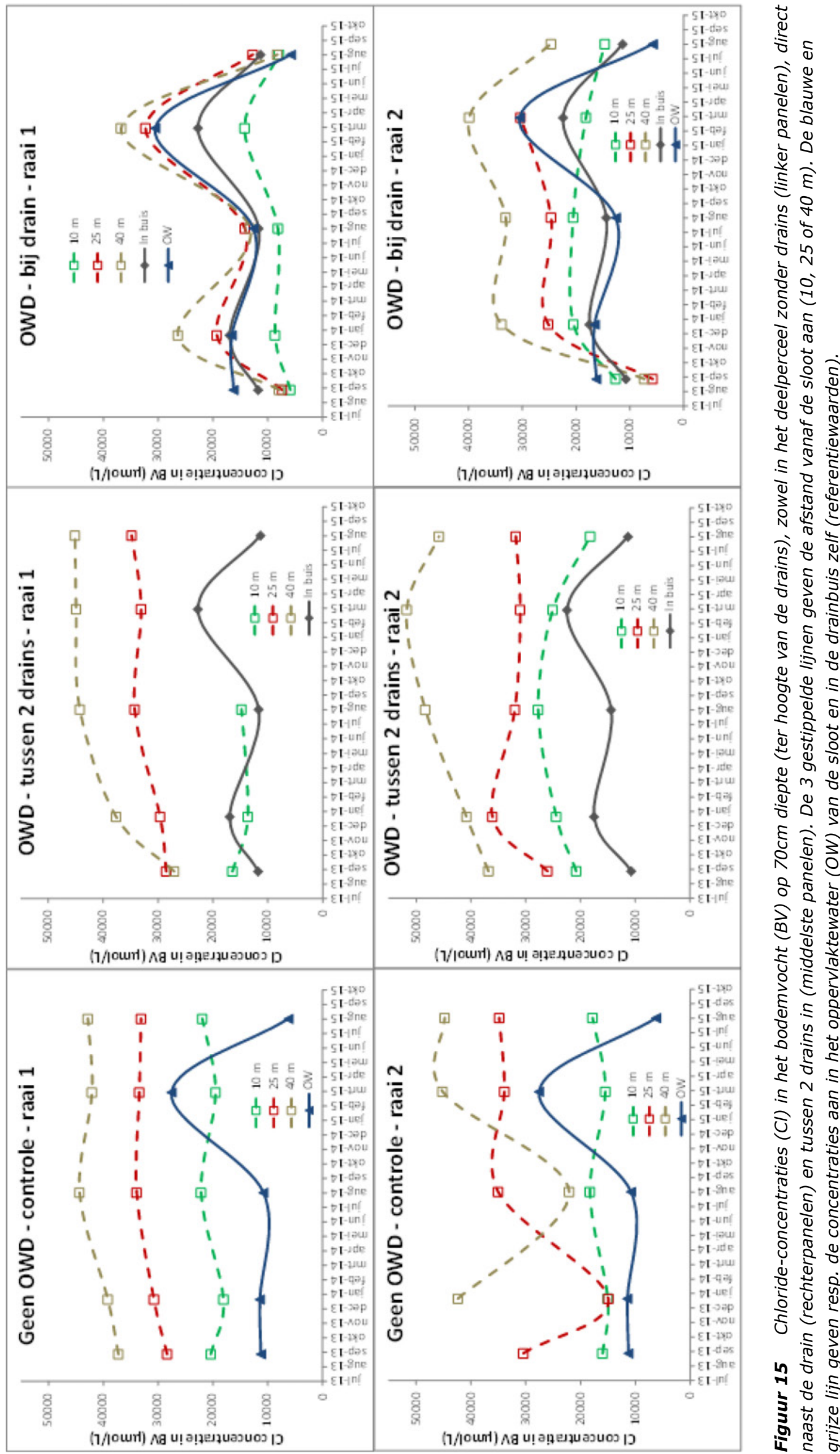
Het blijkt dat met name in de zomermaanden de grondwaterconcentraties totaal-P en $\mathrm{NH} 4+$ in het deel met OWD overal lager zijn dan in REF en dat de concentraties direct naast de drain lager zijn dan tussen de drains. De $\mathrm{NH}_{4}{ }^{+}$-concentratie volgt hierbij goed de concentratie van het oppervlaktewater, maar dit geldt niet voor P. De ortho-P-concentraties in het oppervlaktewater zijn steeds hoger dan de concentraties die worden gemeten in het grondwater. Dit duidt erop dat het $\mathrm{P}$ dat binnenkomt via de drains rondom de drainagebuizen wordt geïmmobiliseerd in de veenbodem.

De $\mathrm{S}$ zit in de vorm van het goed oplosbare sulfaat $\left(\mathrm{SO}_{4}\right)$ in het grondwater. Het verloop van de S-concentratie in het grondwater volgt dan ook ten dele het patroon dat voor $\mathrm{Cl}$ wordt gevonden (Figuur 15). Het verschil is echter dat de S-concentraties in afvoerperiodes veelal lijken te worden beïnvloed door de grondwaterconcentraties gemeten in het midden van het perceel en gedurende aanvoerperiodes door de S-concentraties in het oppervlaktewater.

\subsubsection{Effecten OWD op het oppervlaktewater in de aangrenzende sloot}

Het verloop van de kwaliteit van het water in de sloot met OWD komt sterker overeen met de kwaliteit van het inlaatwater uit de aanvoersloot dan het verloop van de slootwaterkwaliteit in REF. Dit hangt waarschijnlijk samen met de hogere inlaatbehoefte, met name in droge periodes, in de sloot met OWD. In de twee meetjaren vond er echter zowel in de situatie met OWD als in de referentie (REF) vooral afvoer plaats van water. De S-concentraties in het oppervlaktewater laten hoge pieken zien aan het einde van de zomer wanneer de neerslag ook hoog is. De berekende belasting van $\mathrm{S}$ uit het perceel neemt ook toe wanneer de neerslag toeneemt, met name in augustus (Tabel 3). Er vindt dus duidelijk uitspoeling van $\mathrm{SO}_{4}$ plaats uit de percelen.

Tabel 3 Berekende fluxbelasting van $N, P, F e, S$ en $\mathrm{Cl}$ naar het oppervlaktewater in de aangrenzende sloot met en zonder OWD. Via drainagebuizen: aanname dat alles via de buizen is afgevoerd. Via perceel: aanname dat alles via het perceel is afgevoerd.

\begin{tabular}{|c|c|c|c|c|c|}
\hline & Anorg. N & totaal-P & $\mathrm{Fe}$ & $\mathbf{S}$ & Cl \\
\hline & $\mathrm{mmol} / \mathrm{dag}$ & $\mathrm{mmol} / \mathrm{dag}$ & $\mathrm{mmol} / \mathrm{dag}$ & $\mathrm{mmol} / \mathrm{dag}$ & $\mathrm{mmol} / \mathrm{dag}$ \\
\hline \multicolumn{6}{|l|}{ Met OWD } \\
\hline \multicolumn{6}{|l|}{ Via drainagebuizen } \\
\hline jan-14 & 6813 & 734 & 268 & 14939 & 376609 \\
\hline aug-14 & 4965 & 625 & 196 & 10923 & 260523 \\
\hline mrt-15 & 624 & 48 & 9 & 655 & 33589 \\
\hline aug-15 & 9908 & 1081 & 128 & 14080 & 348104 \\
\hline \multicolumn{6}{|l|}{ Via Perceel } \\
\hline jan-14 & 10112 & 635 & 68 & 3862 & 537579 \\
\hline aug-14 & 7813 & 655 & 110 & 12371 & 271403 \\
\hline mrt-15 & 620 & 35 & 64 & 1059 & 36945 \\
\hline aug-15 & 7910 & 536 & 135 & 44025 & 524269 \\
\hline \multicolumn{6}{|l|}{ Zonder OWD } \\
\hline \multicolumn{6}{|l|}{ Via Perceel } \\
\hline jan-14 & 9314 & 813 & 233 & 11752 & 344142 \\
\hline aug-14 & 10877 & 901 & 178 & 10613 & 444853 \\
\hline mrt-15 & 583 & 52 & 22 & 265 & 21180 \\
\hline aug-15 & 22888 & 1763 & 708 & 19501 & 717273 \\
\hline
\end{tabular}

De uit de concentraties en waterflux berekende belasting van P en anorganisch $\mathrm{N}$ (nitraat $\left(\mathrm{NO}_{3}\right)+$ $\mathrm{NH}_{4}$ ) vanuit het perceel naar de sloot (Tabel 3), is lager bij het perceel met OWD dan bij REF. In grote lijnen volgen de totaal-P en fosfaat $\left(\mathrm{PO}_{4}{ }^{3-}\right)$ concentraties in het oppervlaktewater van de sloot ook de concentraties die worden gemeten in het inlaatwater van de aanvoerende sloot. In de droge zomerperiode van 2015 zijn de $\mathrm{P}$ - en $\mathrm{PO}_{4}$-concentraties lager in de OWD-sloot omdat er dan meer water wordt ingelaten met een lagere P-concentratie. In de REF-sloot zijn de P-concentraties dan veel hoger dan in het inlaatwater en in de sloot met OWD, waarschijnlijk als gevolg van nalevering vanuit de bodem. 
De $\mathrm{NO}_{3-}$ en $\mathrm{NH}_{4}$-concentraties zijn lager in de zomermaanden, omdat er dan meer stikstof uit het systeem verdwijnt door gekoppelde nitrificatie-denitrificatie. Ook hier volgt het verloop van de concentratie in de sloot met OWD het patroon dat wordt gevonden in het inlaatwater van de aanvoerende sloot. In de REF sloot zijn de gemeten $\mathrm{NO}_{3}$-concentraties in de zomer vaak lager. Dit ondanks dat er een hogere flux wordt berekend vanuit de percelen (Tabel 3).

\subsection{Bedrijfsvoering}

In 2013 en 2014 is in het voorjaar elke 14 dagen de draagkracht gemeten. De draagkracht komt overeen met de gemeten indringweerstand van een conus met een tophoek van $60^{\circ}$ en basisoppervlakte van $5 \mathrm{~cm}^{2}$. Limietwaarden zijn 0,5 MPa, waarboven berijding mogelijk is zonder te diepe sporen en schade aan de grasmat, en 0,6 MPa waarboven beweiding mogelijk is zonder al te veel vertrapping. De resultaten zijn bijeengebracht in tabellen in Bijlage 3. De resultaten in 2013 en 2014 laten ongeveer hetzelfde beeld zien. Daarom beperken wij ons hier tot de metingen in 2014, omdat deze een duidelijker en vollediger beeld geven dan 2013. In Figuur 16 is de gemiddelde draagkracht van de percelen 3, 4, 5 en 6, elk met een deel zonder onderwaterdrains (referentie) en een deel met onderwaterdrains (drains). Deze zijn in Figuur 16 per perceel steeds paarsgewijs naast elkaar afgebeeld, zodat deze per perceel zijn te vergelijken. (NB De percelen 3 en 4 zijn op 20 maart niet gemeten.) Het blijkt dat gemiddelde draagkracht bij het gedraineerde deel, met uitzondering van perceel 4 op 2 mei, altijd hoger is dan de referentie zonder drains. De percelen met de laagste draagkracht blijken de percelen 3 en 6 te zijn.

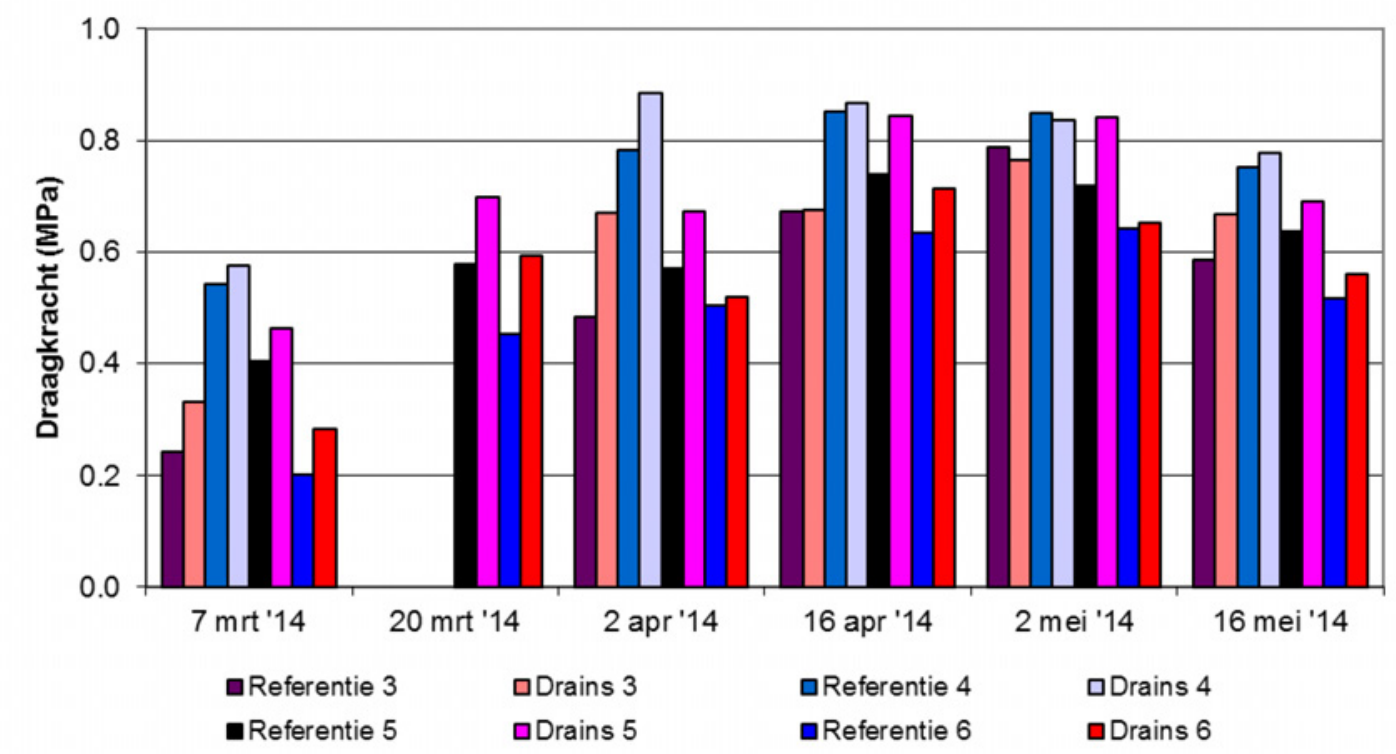

Figuur 16 Draagkracht gemeten als de indringweerstand met een conus van $5 \mathrm{~cm}^{2}$ in de periode begin maart tot half mei 2014. Gemiddelde van 20 punten per perceeldeel.

Een gemiddelde draagkracht zegt niet alles. Een serie punten met een extra lage of juist een extra hoge indringweerstand kan het gemiddelde sterk beïnvloeden, terwijl gedeelten van een perceel met een lage draagkracht kunnen bepalen of het perceel als geheel kan worden beweid of bereden.

Daarom zijn in Figuur 17 het percentage punten met voldoende draagkracht voor berijden of beweiden aangegeven. Hieruit komt een genuanceerder beeld dan uit Figuur 16 met de gemiddelde draagkracht. Terwijl de gemiddelde draagkracht op 16 april en 2 mei voor alle percelen boven de 0,6 MPa ligt en dus goed berijdbaar, blijkt uit Figuur 17 dat dit bij een paar percelen slechts voor $60 \%$ van het aantal punten geldt. Uit Figuur 17 blijkt dat onderwaterdrains in het algemeen een positieve uitwerking hebben op de draagkracht, met name in de nattere perioden. Uit zowel Figuur 16 als 17 blijkt dat de draagkracht op de gedraineerde perceeldelen eerder in het seizoen voldoende is voor berijden of beweiden dan bij de referenties. 

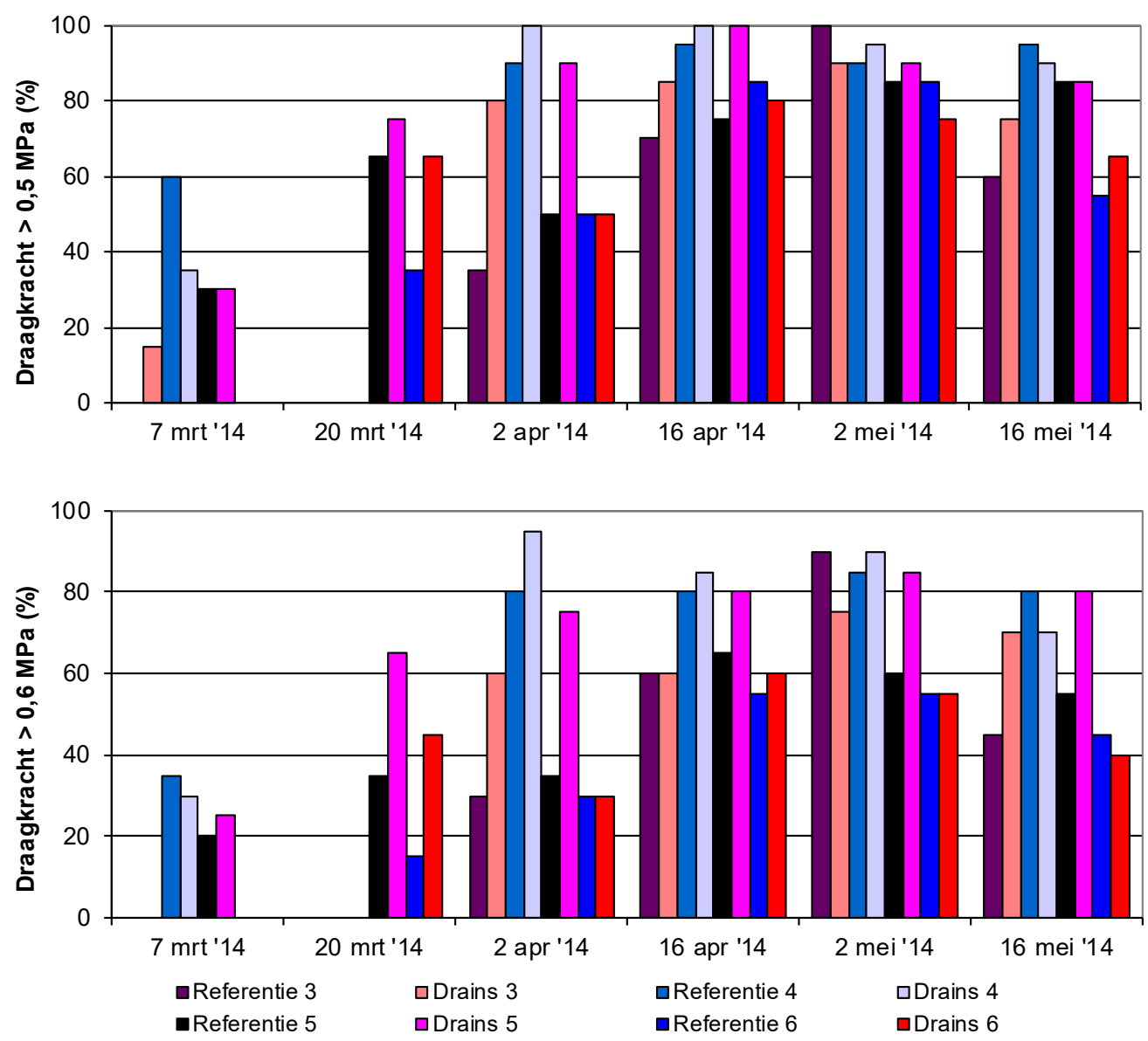

Figuur 17 Het percentage van het aantal metingen (punten) waar een hogere draagkracht is gemeten dan de limietwaarde voor berijden ( $0,5 \mathrm{MPa}$, bovenste figuur) en de limietwaarde voor beweiden $(0,6 \mathrm{MPa}$, onderste figuur). Het aantal gemeten punten per perceeldeel is 20 .

Het is de vraag of de agrariër de gemeten verbeterde draagkracht door toepassing van onderwaterdrains ook uit eigen ondervinding als zodanig ervaart. Uit het interview blijkt dat er op de gedraineerde delen wat minder plasvorming optreedt. Verder worden er geen grote verschillen waargenomen tussen de referentiedelen en de delen met onderwaterdrains. Op de vraag of de agrariër meer percelen zou draineren indien de kosten beperkt zijn, werd positief geantwoord. Wel zouden dan de eindbuizen zo veel mogelijk moeten worden beperkt en geconcentreerd op een beperkt aantal meters slootrand. De kosten zouden niet meer mogen bedragen dan $€ 1000$ per ha. De inzet van de baggerpomp in combinatie met de smalle sloot en de (verlengde) eindbuizen aan twee kanten van de sloot was erg lastig. Ook bij slootschonen is de aanwezigheid van eindbuizen aan twee kanten een probleem. De eindbuizen beperken tot één slootkant zou bij zowel het baggeren met de baggerspuit als bij het slootschonen al veel helpen. Al met al worden de onderwaterdrains positief gewaardeerd, maar vormen de verlengde eindbuizen een probleem.

\subsection{Geschiktheid voor weidevogels}

Om te bepalen of er verschillen zijn tussen de geschiktheid voor weidevogels voor perceeldelen met of zonder onderwaterdrains zijn in het vroege voorjaar elke 14 dagen de indringweerstanden met een conus van $60^{\circ}$ en een basisoppervlakte van $1 \mathrm{~cm}^{2}$ bepaald. Daarnaast zijn graslengten gemeten en is zo goed mogelijk het tijdstip van bloei van het gras bepaald. De metingen in 2014 bleken de meeste informatie te bevatten. He bleek dat in 2013 de indringweerstanden maar in een heel enkel geval onder de 0,25 MPa bleef. Wel zijn de meetresultaten van beide jaren verzameld en in Bijlage 3 gepresenteerd. 
In Figuur 18 zijn de indringweerstanden van alle percelen van de referenties en de delen met drains op dezelfde wijze met elkaar vergeleken als bij de draagkracht. In dit geval gaat het erom dat de indringweerstand onder de 0,25 MPa moet blijven. Hoe lager hoe beter dus. Een gemiddelde indringweerstand lager dan 0,25 wordt alleen op 7 maart op het referentiedeel van perceel 3 gehaald. Vooral perceel 4 is bij zowel de referentie als bij de drains de indringweerstand veel hoger dan 0,25 MPa. Dit wordt misschien veroorzaakt door de aanwezigheid van een ca. $15 \mathrm{~cm}$ dikke kleilaag op het veen. Deze is echter ook aanwezig op perceel 3, hoewel minder zwaar. In Figuur 19 is aangegeven welk percentage van de metingen (punten) voldoen aan het criterium van < 0,25 MPa. Net als bij de draagkracht blijkt dat een genuanceerder beeld op te leveren. Het blijkt dat de percelen 3 en 6 het geschiktst zijn voor weidevogels, maar ook perceel 5 doet het vooral in het begin van het seizoen redelijk goed. Perceel 4 is duidelijk het minst geschikt voor weidevogels. Het aantal punten met voldoend lage indringweerstand bij de perceeldelen met onderwaterdrains is in het algemeen duidelijk lager dan bij de referentie. In alle gevallen blijken onderwaterdrains de geschiktheid voor foerageren voor weidevogels met een derde of meer te verlagen.

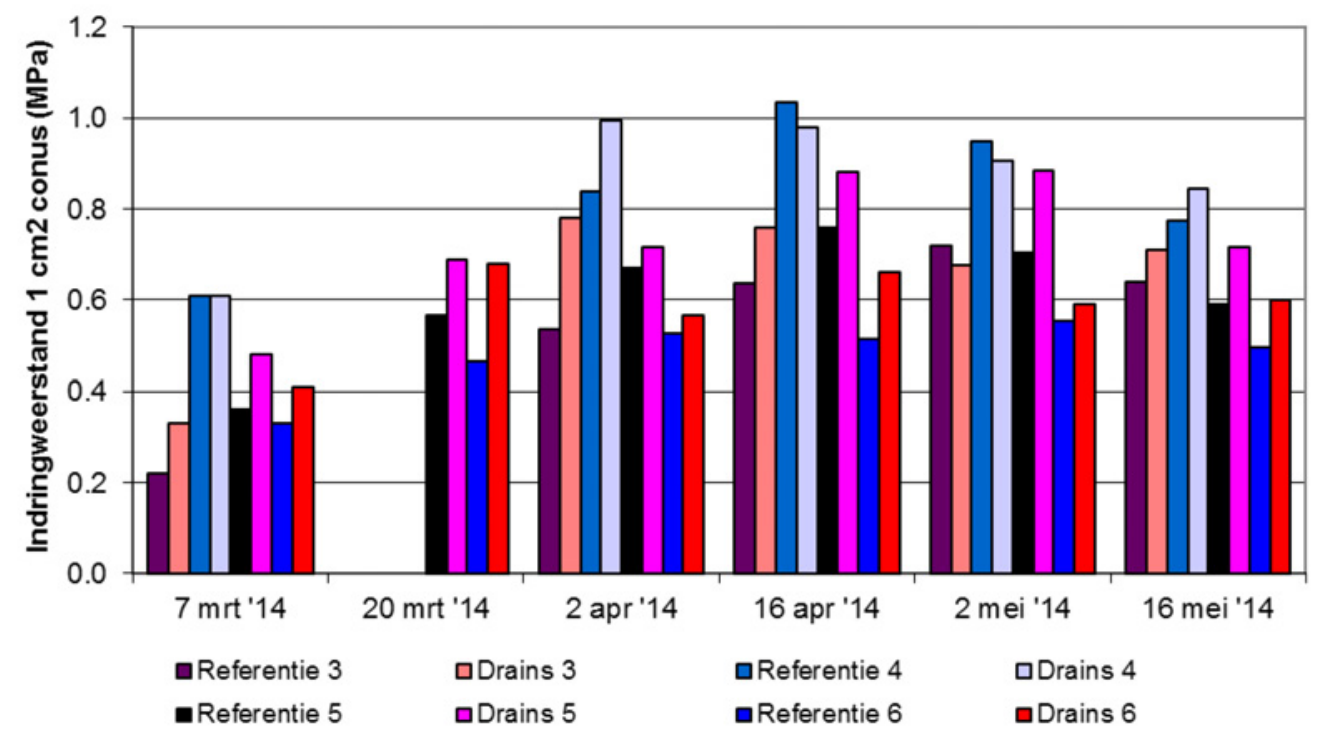

Figuur 18 Geschiktheid voor het foerageren van weidevogels gemeten aan de hand van de gemiddelde indringweerstand met een conus van $1 \mathrm{~cm}^{2}$ in de periode begin maart tot half mei 2014. Gemiddelde van 20 punten per perceeldeel. Een indringweerstand > 0,25 MPa is te hoog voor weidevogels.

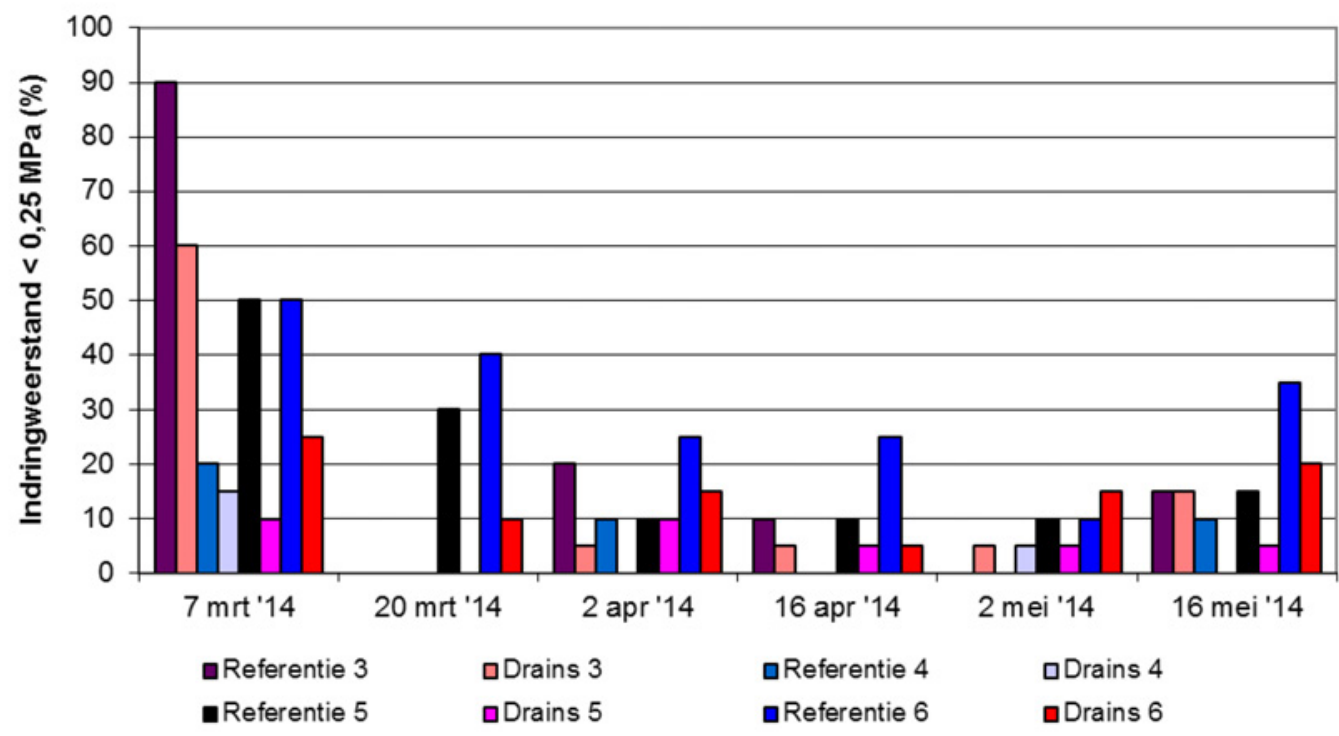

Figuur 19 Geschiktheid voor het foerageren van weidevogels uitgedrukt in het percentage van het aantal metingen (punten) waar een lagere indringweerstand is gemeten dan de limietwaarde voor het foerageren van weidevogels (0,25 MPa). Het aantal gemeten punten per perceeldeel is 20. 
De toepassing van onderwaterdrains zou, doordat de grond sneller droog is en daardoor ook sneller opwarmt, kunnen leiden tot een vroegere en snellere groei van het gras. Een snelle groei van het gras kan leiden tot problemen voor weidevogelkuikens die geconfronteerd worden met hoog en dicht gras, waardoor zij zich moeilijk kunnen (voort)bewegen. In 2013 zijn op de percelen 5 en 6 en in 2014 op de percelen $3 \mathrm{t} / \mathrm{m} 6$ de hoogte van het gras gemeten op 20 plekken per perceeldeel met en zonder onderwaterdrains. De resultaten zijn gepresenteerd in Figuur 20. De verschillen in grashoogte blijken nihil. Er lijkt hoogstens een lichte verlaging van de grashoogte op te treden door de toepassing van onderwaterdrains. Voor de weidevogelkuikens zijn wat betreft de problemen met de grashoogte geen verschil in problemen te verwachten tussen de referenties en de drains.

Door een snellere en betere grasgroei bij toepassing van onderwaterdrains zou het gras ook eerder bloeien. Ee vroege bloei met de bijbehorende piek in het voorkomen van insecten - een belangrijke voedselbron voor de kuikens - kan daardoor te vroeg zijn voor de kuikens, waardoor later mogelijk voedselschaarste ontstaat. Er zijn geen verschillen in moment van bloei geconstateerd tussen de referenties en de drains. Ook tussen de percelen onderling was er niet veel verschil.

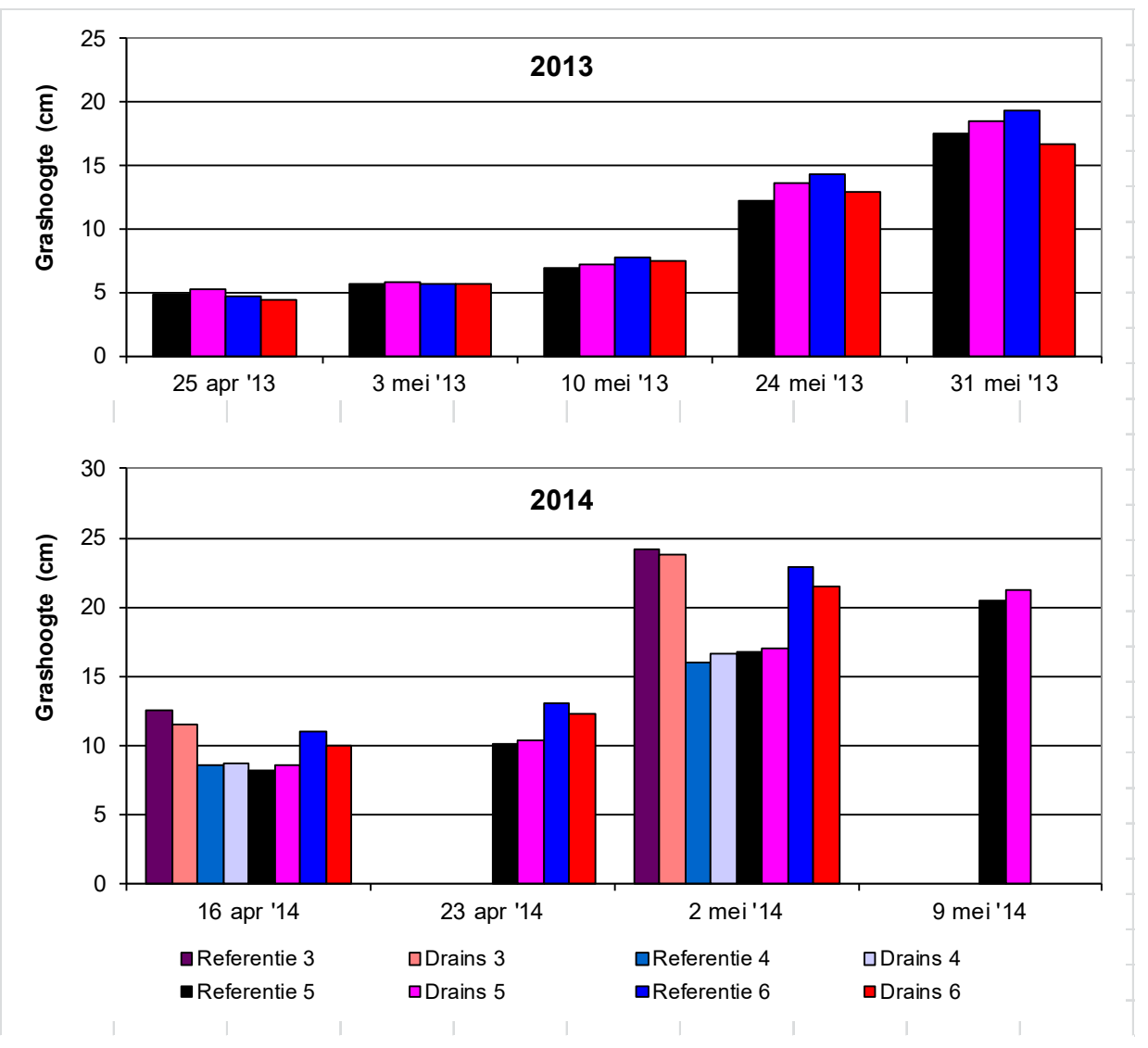

Figuur 20 Grashoogte in cm in 2013 en 2014.

\subsection{Vergelijking met de pilot Zeevang 3}

Er zijn in de polder Zeevang drie pilots met onderwaterdrains geweest (Hoving et al., 2009, 2011, 2015) waarvan de laatste, pilot Zeevang 3 (Hoving et al., 2015) het best te vergelijken is met de pilot in het Wormer- en Jisperveld. Belangrijke overeenkomsten zijn dat ook de veengrond bij Zeevang 3 slecht doorlatend was: bij Wormer- en Jisperveld ca. $2 \mathrm{~cm} /$ dag en bij Zeevang $3 \mathrm{ca} 4 \mathrm{~cm} / \mathrm{dag}$, zodat de drainafstand bij beide locaties moest worden beperkt tot 4 meter. Daarnaast hadden ook de sloten bij Zeevang 3 een baggerprobleem, hoewel dit probleem in het Wormer- en Jisperveld zichtbaar groter is dan in de polder Zeevang. Bij zowel de pilot Wormer- en Jisperveld als bij Zegveld 3 is getracht de instroom van bagger in de drains zo veel mogelijk te beperken door de eindbuizen te verlengen met 
ca. 1,20 m drainbuis met omhullingsmateriaal, die aan het einde is afgesloten met een dop. Hoewel de tussensloot in de pilot Wormer- en Jisperveld regelmatig werd uitgebaggerd, bleef het baggerprobleem hardnekkig vrij spoedig terugkeren en uit de metingen volgt dan ook dat in ieder geval de infiltratie via de drains niet bij elke drain even goed was. In de polder Zeevang was het probleem minder groot en functioneerden de OWD duidelijk beter. Dit blijkt uit de Figuren 21 en 22 uit Hoving et al., 2015. Bij perceel 13 van Zeevang 3 blijkt bij een drooglegging jaarrond van ca. $55 \mathrm{~cm}$ dat in de droogste periode in zomer 2013 de grondwaterstand met ca $10 \mathrm{~cm}$ omhoog wordt gebracht. Een kanttekening hierbij is dat bij de pilot Wormer- en Jisperveld het grondwater duidelijk minder diep (ca. $30 \mathrm{~cm}$ ) onder het slootpeil uitzakt dan bij Zeevang 3 (ca. $50 \mathrm{~cm}$ ). Waarschijnlijk komt dit doordat bij Zeevang 3 een vrij dunne veenlaag van ca. $130 \mathrm{~cm}$ op een zware, zeer slecht doorlatende klei ligt. Bij de referentie zonder drains moet het water uit de sloot via de laag veen van $130 \mathrm{~cm}$ dikte naar het midden van het perceel stromen. Bij de pilot Wormer- en Jisperveld is deze veenlaag veel dikker en is daardoor de mogelijkheid van toestromen van water veel beter.

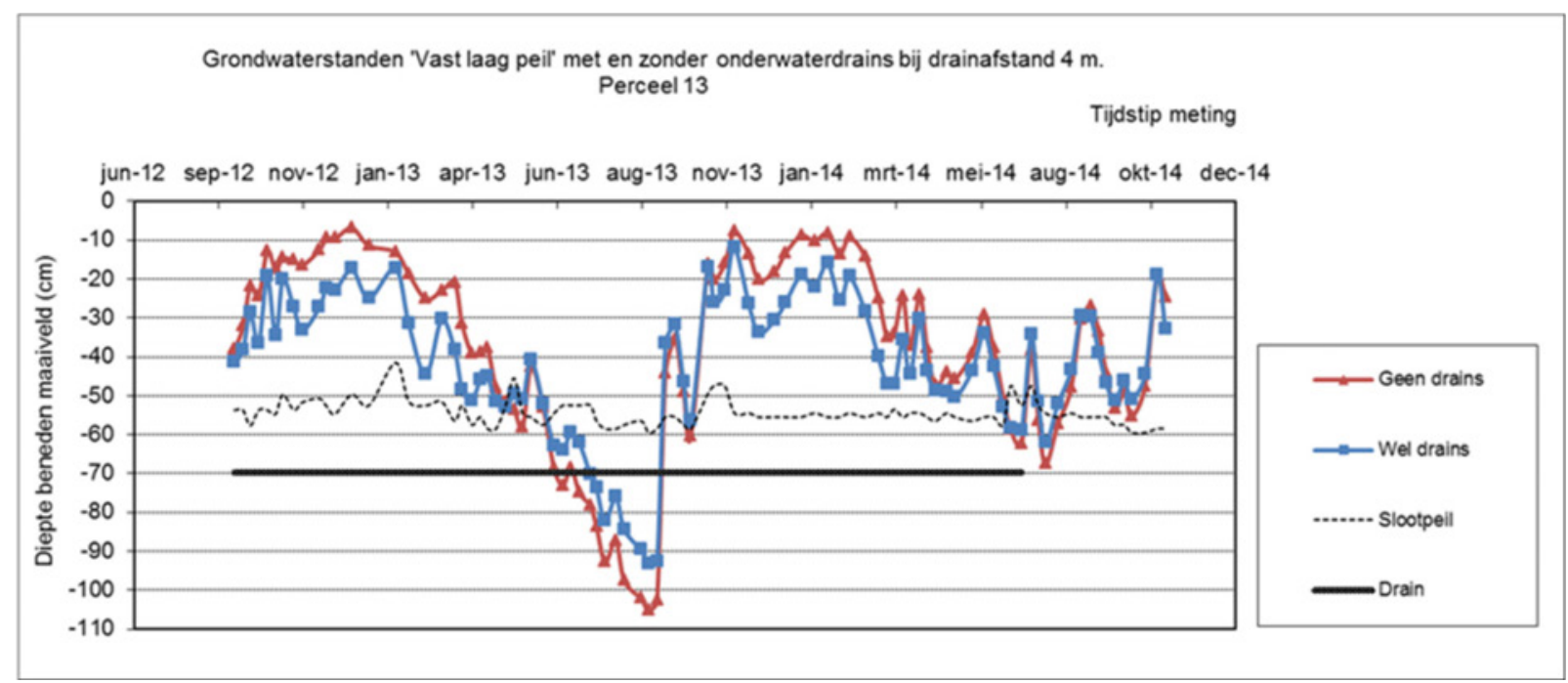

Figuur 21 Grondwaterstanden perceel 13 Zeevang 3 zonder en met drainage (drainafstand $4 \mathrm{~m}$ ) en het slootpeil weergegeven ten opzichte van het maaiveld van de ongedraineerde situatie (cm maaiveld) (uit Hoving et al., 2015).

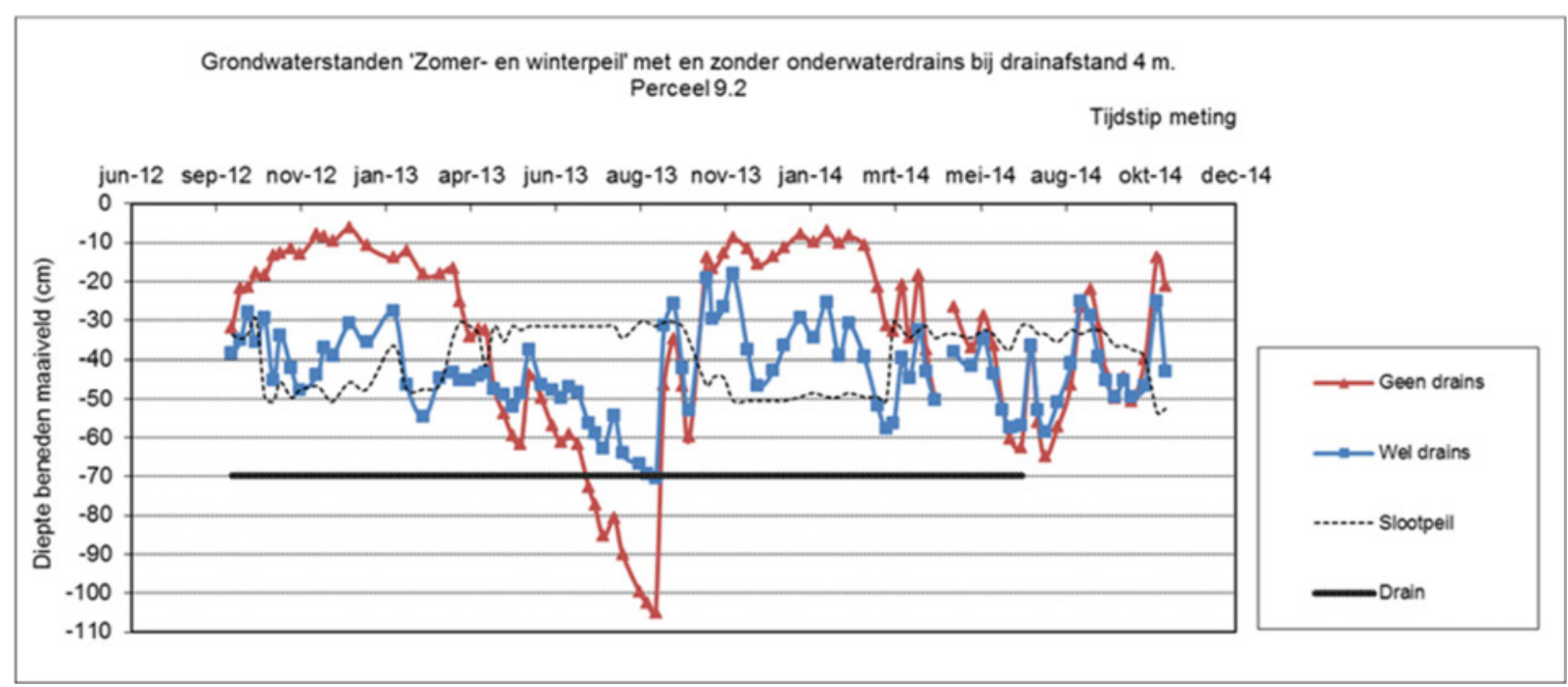

Figuur 22 Grondwaterstanden perceel 9.2 Zeevang 3 zonder en met drainage (drainafstand $4 \mathrm{~m}$ ) en het slootpeil weergegeven ten opzichte van het maaiveld van de ongedraineerde situatie (cm maaiveld) (uit Hoving et al., 2015). 
Bij perceel 9.2 van Zeevang 3 wordt in de zomerperiode het slootpeil opgezet. Het winterpeil heeft een drooglegging van ca. $50 \mathrm{~cm}$ en het zomerpeil een drooglegging van $30 \mathrm{~cm}$. Bij de referentie zonder OWD heeft het hogere zomerpeil geen merkbaar effect op de grondwaterstand, deze zakt in perceel 9.2 (Figuur 22) net zoveel uit als in perceel 13 (Figuur 21). De OWD blijken effectief om het hogere zomerpeil daadwerkelijk te laten resulteren in een hogere grondwaterstand: deze is ca. $35 \mathrm{~cm}$ hoger dan in de referentie.

De vergelijking met Zeevang 3 laat zien dat de toepassing van onderwaterdrains de grondwaterstand effectief kan verhogen en daarmee de maaivelddaling kan beperken. Verhoging van het slootpeil blijkt bij de referentie (dus zonder OWD) niet effectief om de grondwaterstand te verhogen. Bij toepassing van OWD blijkt een hoger zomerpeil juist wel zeer sterk door te werken in een verhoging van de grondwaterstand.

\subsection{Kosten en baten OWD}

De aanlegkosten van onderwaterdrains zijn ongeveer 1 euro per strekkende meter. Bij de veelvoorkomende drainafstand van $6 \mathrm{~m}$ is dit ongeveer 1700 euro per ha. Bij een drainafstand van $4 \mathrm{~m}$, zoals in Wormer- en Jisperveld en Zeevang 3, zijn de aanlegkosten ongeveer 2500 euro per ha.

In de pilot Wormer- en Jisperveld is het economische voor- of nadeel voor de veehouder niet beschouwd. Voor een beschouwing van de kosten en baten van OWD wordt daarom teruggevallen op eerder onderzoek aan onderwaterdrains (STOWA, 2015; Hoving et al., 2015). Daaruit blijkt dat de bruto grasopbrengsten niet of maar beperkt worden verhoogd. Het lijkt erop dat de verminderde veenoxidatie en de daaruit volgende verlaagde stikstokmineralisatie leidt tot een lagere grasopbrengst. Dit blijkt echter te worden gecompenseerd door een betere nutriëntenbenutting doordat het perceel door de OWD wat droger blijft. Het zou kunnen dat op de lange duur door een verbetering van de grasmat de grasopbrengsten wel zullen stijgen. De netto grasopbrengst, dat wil zeggen de grasopbrengst die daadwerkelijk van het land wordt gehaald en in de maag van de koe belandt, is in het algemeen significant hoger bij de toepassing van OWD. Dit komt omdat de berijdbaarheid en beweidbaarheid van het land verbetert waardoor minder vertrappings- en berijdingsverliezen optreden en de beweidingsperiode langer wordt. Daarnaast worden de voordelen van het beperken van de maaivelddaling op den duur steeds groter: een holle ligging van het perceel wordt voorkomen en op den duur wordt de drooglegging van percelen met OWD relatief steeds beter ten opzichte van percelen zonder OWD. Daarnaast wordt de bedrijfszekerheid vergroot en wordt het bedrijf ook meer "climate-proof".

Van Hardeveld et al. (2014) berekenden in een maatschappelijke kosten-batenanalyse (MKBA) voor de middellange termijn (tot 2050) een batig economisch saldo voor de maatschappij als geheel van $€ 200$ tot $€ 300$ per hectare per jaar bij toepassing van OWD in het Groene Hart. Dit vooral door kostenbesparingen (onder ander beperking $\mathrm{CO}_{2}$-emissies) en betere mogelijkheden voor het bedrijfsleven. Dit zou reden kunnen zijn om de toepassing van OWD te subsidiëren. Een subsidie van $50 \%$ in de aanlegkosten zou in bijna alle gevallen de toepassing van OWD voor de veehouderij rendabel maken. Voor de lange termijn zou dit zeker het geval zijn. Het grote probleem zal op dit moment (het jaar 2016) echter vooral zijn dat door de lage melkprijzen de investeringsruimte voor de veehouderij nihil is. 


\section{Conclusies en Aanbevelingen}

De aandachtsgebieden voor het effect van de toepassing van onderwaterdrains die in dit onderzoek aan bod moesten komen, waren:

- de maaivelddaling;

- de waterkwantiteit, met name de vraag in de zomer;

- de waterkwaliteit;

- de bedrijfsvoering (draagkracht);

- de geschiktheid voor weidevogels.

Samengevat staan hieronder de conclusies voor elk van deze punten.

\subsection{Conclusies}

\section{Maaivelddaling}

De gemeten maaivelddalingen bleken bij zowel de perceeldelen met OWD als de referentie (REF) gemiddeld slechts 1 tot $2 \mathrm{~mm}$ per jaar te zijn over een periode van 4 jaar. Naar verwachting en uit ervaring weten we dat meerdere jaren noodzakelijk zijn om een trend in de maaivelddalingen te meten. Dit wordt vooral veroorzaakt doordat de maaivelddaling sterk afhangt van de diepste grondwaterstand, die in het algemeen in de periode eind augustus tot half september wordt bereikt en die op zijn beurt sterk afhankelijk is van hoe droog de zomer is geweest. Nederland kent nu al een reeks van jaren met vrij natte zomers, waardoor helaas na 4 jaar geen grote maaivelddalingen te meten zijn en de verschillen tussen wel of geen OWD niet goed meetbaar zijn, zodat in ieder geval voorlopig geen uitspraken kunnen worden gedaan over de beperking van de maaivelddaling door de toepassing van OWD.

\section{Waterkwantiteit}

Als eerste wordt onder deze noemer de drainerende en infiltrerende werking van de drains beschouwd aan de hand van de grondwaterstanden. De grondwaterstanden in de perceeldelen met OWD hebben in natte perioden lagere grondwaterstanden. De drainerende functie van OWD lijkt goed te voldoen. De infiltrerende functie lijkt echter tegen te vallen. Verschillen in grondwaterstand in de raaien op dezelfde perceeldelen met onderwaterdrains lijken erop te duiden dat er drains zijn die goed tot matig infiltreren en andere die duidelijk slechter functioneren. Het beeld lijkt te worden bevestigd door de waterkwaliteitsmetingen. Een verklaring zou het blijvende probleem van te veel bagger in de sloot kunnen zijn. Voortdurend ontstaat na uitbaggeren nieuwe bagger.

Piekafvoeren door hevige regenbuien blijken bij de referentiedelen duidelijk groter te zijn dan bij de perceeldelen met drains. Hoewel zowel bij de drains als bij de referentie veel water via de greppels en greppelbuizen snel naar de sloten stroomt, blijkt bij beide ook een groot deel van de neerslag in de bodem te worden geborgen. De bergingsmogelijkheid van de referentie is echter zoveel kleiner dan die van de perceeldelen met onderwaterdrains, dat bij de referenties de berging veel sneller vol is en de grondwaterstand tot in het maaiveld stijgt, waarna het regenwater snel via de oppervlakte en greppels wordt afgevoerd.

De infiltratie van water via de onderwaterdrains valt tegen. Omdat eerder in het jaar in de natte periode het grondwater hoger staat dan het slootpeil wordt er tot in mei via de drains meer water afgevoerd dan bij de referentie. De watervoorraad in de grond waarmee de zomer wordt ingegaan, is bij de drains daardoor kleiner dan bij de referentie. Dit verlies aan watervoorraad wordt later in de zomer niet voldoende goed gemaakt door een betere infiltratie via de drains. Het blijkt dat het neerslagtekort in mei en in de droge zomermaanden in het algemeen veel groter is dan de hoeveelheden water die vanuit de slootcompartimenten in het perceel infiltreren. De maximale infiltratie via de drains is in de droogste periode maximaal ca. $1 \mathrm{~mm}$ per dag. Hoewel via de drains 
twee- tot driemaal meer water infiltreert dan bij de referentie, blijken de grondwaterstanden bij de drains toch enkele centimeters dieper onder het slootpeil uit te zakken dan bij de referentie. Wel kan het zijn dat de zone direct boven de grondwaterstand bij de drains natter blijft dan bij de referentie, zodat er wel minder zuurstof in de grond zit en de veenoxidatie en maaivelddaling beperkt blijven.

De infiltrerende en drainerende werking van de onderwaterdrains blijkt ongeveer $1 / 3^{\text {de }}$ te zijn van die zoals in het ontwerp berekend en is daarmee dus slechter dan verwacht. Zoals eerder aangegeven, is de belangrijkste oorzaak hiervan waarschijnlijk de bagger in de sloot.

\section{Waterkwaliteit}

Door B-Ware zijn de volgende conclusies getrokken wat betreft de effecten van OWD op de waterkwaliteit:

- De toepassing van OWD lijkt jaarrond een effect te hebben op de grondwaterkwaliteit. De concentraties van alle ionen worden verlaagd in de zomerperiode waarin er sprake is van infiltratie van oppervlaktewater.

- Dit effect is echter alleen meetbaar direct bij de OWD-buizen. Midden tussen de drains in (deze liggen steeds $4 \mathrm{~m}$ uit elkaar) is het effect niet meer meetbaar.

- Van de twee raaien met drains die zijn gemonitord laat één raai dit effect duidelijk zien, de andere niet. Dit doet vermoeden dat niet alle drains even goed hebben gewerkt.

- De verschillen tussen de deelpercelen met en zonder OWD zijn groot, waardoor het niet goed mogelijk is om het effect van OWD op de uitspoeling van nutriënten hard te maken. De berekeningen, voor wat ze waard zijn, laten zien dat OWD niet leiden tot een verhoogde uitspoeling van stikstof en fosfor.

- De effecten van OWD op de oppervlaktewaterkwaliteit worden sterk bepaald door de mate waarin er aanvoer van water nodig is in de droge tijd (waarin er infiltratie plaatsvindt van oppervlaktewater in de percelen). De toepassing van OWD heeft hierdoor wel invloed op de oppervlaktewaterkwaliteit.

- $\mathrm{Er}$ is een sterke gradiënt van de ionenconcentraties (chloride, calcium, magnesium, ammonium en fosfor) in de percelen van het midden naar de rand. Concentraties nemen richting het midden van het perceel steeds verder toe vanaf de sloot waar de oppervlaktewaterkwaliteit werd gemeten. Dit geldt zowel voor het deelperceel met OWD als zonder OWD.

- Uitspoeling van ionen en nutriënten uit het perceel is sterk bepalend voor de oppervlaktewaterkwaliteit in het gebied.

\section{Bedrijfsvoering}

Uit de draagkrachtmetingen volgt dat de draagkracht door de toepassing van onderwaterdrains toeneemt. Het blijkt dat de draagkracht op de gedraineerde perceeldelen eerder in het seizoen voldoende is voor berijden of beweiden dan bij de referenties. De agrariër merkt vooral dat er minder plasvorming is op de perceeldelen met onderwaterdrains. Andere grote verschillen worden niet waargenomen. De agrariër staat positief tegenover onderwaterdrains en zou maximaal $€ 1000$ per ha daarin willen investeren. Wel zouden dan de eindbuizen zo veel mogelijk moeten worden beperkt en geconcentreerd op een beperkt aantal meters slootwand.

\section{Geschiktheid voor weidevogels}

Het blijkt dat door toepassing van OWD de indringweerstand toeneemt, waardoor een groter deel van het perceel minder geschikt wordt voor foerageren door weidevogels. In alle gevallen blijken OWD de geschiktheid voor foerageren voor weidevogels met een derde of meer te verlagen. Alleen de meting van de indringweerstand bleek verschillen tussen de referenties en de drains op te leveren.

Grashoogtemetingen lieten geen verschillen zien en ook werd het moment van bloeien van het gras niet duidelijk beïnvloed.

\subsection{Aanbevelingen}

De baggerproblematiek blijkt bij de toepassing van OWD tot slechter functioneren van de infiltrerende werking van onderwaterdrains te kunnen leiden. Het effect van de bagger op de drainerende werking lijkt beperkt te zijn en de belofte dat de draagkracht wordt verbeterd, wordt waargemaakt. Echter, de infiltratie blijkt door de baggerproblematiek slechts $1 / 3^{e}$ te zijn van de verwachte infiltratie. Om deze 
situatie te verbeteren, wordt aanbevolen om de drains niet in de sloot en feitelijk in de bagger te laten uitkomen, maar op centrale punten waardoor er mogelijkheden ontstaan om alleen redelijk schoon water te infiltreren. Een dergelijk centraal punt kan bestaan uit een put waarop de individuele onderwaterdrains in een waaiervorm bijeenkomen. Een andere mogelijkheid is dat de drains uitkomen op een collectordrain (verzameldrain) die vervolgens uitkomt in de put. Om ervoor te zorgen dat het infiltrerende water zo schoon mogelijk is, wordt het water in de put ingelaten over de eerste 10 tot $15 \mathrm{~cm}$ onder het slootpeil. Voorkomen moet worden dat zich te veel bagger in de put verzamelt. De bagger zal daarom regelmatig uit de put moeten worden gepompt. Er zijn misschien ook mogelijkheden om in het onderste deel van de put een afsluitbare opening te maken die bij drainafvoer wordt opengezet en bij infiltratie gesloten. Het is ook mogelijk om de in- en/of uitlaat met behulp van een pomp te regelen. Dat maakt het ook mogelijk om te gaan sturen op het grondwaterpeil (zie bijvoorbeeld het project "Sturen met water": http://www.veenweiden.nl/sturenmet-water/), waarop allerlei varianten kunnen worden bedacht. Zo is het bijvoorbeeld ook mogelijk om in de put water van een nabijgelegen hoger slootpeil in te laten, zodat er meer en beter water infiltreert in het perceel en de grondwaterstand tot boven het aanliggende slootpeil kan worden gestuwd. In het Wormer- en Jisperveld is deze mogelijkheid zeker aanwezig.

De proeven in de pilot Zeevang 3 laten zien dat een verhoging van het peil in een put sterk zal doorwerken in een hogere grondwaterstand (Figuur 22). Voor een dergelijk systeem met een verhoogd peil in een put wordt de term "drukdrains" gebruikt (http://www.veenweiden.nl). Door de put een eind boven het maaiveld uit te laten steken, kan men namelijk zelfs een overdruk tot boven het maaiveld aanbrengen. Daarbij zal men de grondwaterstand goed in de gaten moeten houden om deze niet te veel te laten stijgen.

Uit de resultaten van de pilot Wormer- en Jisperveld blijkt dat OWD niet alleen de draagkracht verhogen, maar in het verlengde daarvan ook de omstandigheden voor weidevogels kunnen verslechteren. Echter, met een systeem met OWD met een dynamisch (hoog) slootpeil of een systeem met een put waarbij via OWD de grondwaterstand wordt gemanipuleerd, kunnen percelen uitstekend in een optimale conditie worden gebracht voor weidevogels. Zelfs tijdens te droge voorjaren voor weidevogels zijn deze optimale omstandigheden gemakkelijk te creëren. Na het weidevogelseizoen zou men vervolgens de grondwaterstand snel omlaag kunnen brengen voor beweiden of berijden. Dit kan zeer snel gaan, omdat in het groeiseizoen de grasverdamping ervoor zorgt dat de draagkracht van de grond zeer snel toeneemt.

De kosten van een systeem waarbij de grondwaterstand kan worden gemanipuleerd, zullen duidelijk groter zijn dan van een eenvoudig systeem waarbij de OWD simpelweg op een sloot uitkomen. De investeringskosten kunnen tot ongeveer het dubbele oplopen, maar waarschijnlijk kunnen besparingen worden gerealiseerd door slim gebruik te maken van de omstandigheden, zoals nabijgelegen hogere slootpeilen en door zo veel mogelijk naar eenvoudige oplossingen te zoeken. Naar verwachting kunnen voor kwetsbare gebieden de voordelen zo groot zijn, dat deze de investeringen zeker waard zijn.

Aanbevolen wordt om de mogelijkheden van OWD gecombineerd met centrale putten en eventueel als drukdrains te onderzoeken voor het Wormer- en Jisperveld. Daarbij zou ook moeten worden onderzocht wat de mogelijkheden zijn voor optimalisatie van percelen voor weidevogels. 


\section{Literatuur}

Akker, J.J.H. van den, J. Beuving \& K. Oostindie, 1993. Berijdingsmogelijkheden veengrasland I: Draagkracht en uitrijmogelijkheden in het voorjaar. In: H. Snoek (ed.), Grasland en berijding; inleidingen van de themadag op donderdag 17 juni 1993. Lelystad, PR, 1993, blz. 1926.

Akker, J.J.H. (Jan) van den, Rob Hendriks, Idse Hoving en Matheijs Pleijter, 2010. Toepassing van onderwaterdrains in veenweidegebieden. Effecten op maaivelddaling, broeikasgasemissies en het water. Werkgemeenschap voor Landschapsonderzoek (WLO), Utrecht, Landschap 27/3, 137-149.

Akker, J.J.H. van den, R.F.A. Hendriks, I.E. Hoving, J. van Kleef, B. Meerkerk, M. Pleijter en A. van den Toorn, 2013. Pilot onderwaterdrains Krimpenerwaard. Wageningen, Alterra Wageningen UR, Alterra-rapport 2466.

Beuving, J., K. Oostindie en Th. Vellinga, 1989. Vertrappingsverliezen door onvoldoende draagkracht van veengrasland. Wageningen, Staring Centrum rapport 6, $31 \mathrm{pp}$.

Hardeveld, H. van, M. van der Lee, J. Strijker, A. van Bokhoven en H. de Jong, 2014. Toekomstverkenning Bodemdaling. Eindrapport fase 1. Versie: Definitief, 8 september 2014. Houten, Hoogheemraadschap De Stichtse Rijnlanden.

Hendriks, R.F.A., J.J.H. van den Akker, K. van Houwelingen, J. van Kleef, M. Pleijter en A. van den Toorn, 2013. Pilot onderwaterdrains Utrecht. Wageningen, Alterra Wageningen UR, Alterra-rapport 2479.

Hendriks, R.F.A., J.J.H. van den Akker, P.C. Jansen en H.Th.L. Massop, 2014. Effecten van onderwaterdrains in peilvak 9 van polder Groot-Wilnis Vinkeveen. Modelstudie naar de effecten van onderwaterdrains op maaivelddaling, waterbeheer, wateroverlast en waterkwaliteit in peilvak 9. Wageningen, Alterra Wageningen UR, Alterra-rapport 2480.

Holshof, G., Th.V. Vellinga en J. Beuving, 1994. Vertrapping en grasaanbod op veengrasland met een slechte draagkracht. Proefstation voor de Rundveehouderij, rapport 153, Lelystad.

Hoving, I.E., G. André, J.J.H. van den Akker en M. Pleijter, 2008. Hydrologische en landbouwkundige effecten van gebruik van 'onderwaterdrains' op veengrond. Rapport 102 Animal Sciences Group, Wageningen UR, 68 blz.

Hoving, I.E., J.J.H. van den Akker en M. Pleijter, 2009. Hydrologische en landbouwkundige effecten toepassing onderwaterdrains in polder Zeevang. Wageningen UR Livestock Research, rapportnummer 188 .

Hoving, I.E., J.J.H. van den Akker, M. Pleijter en K. van Houwelingen, 2011. Hydrologische en landbouwkundige effecten toepassing onderwaterdrains in polder Zeevang. Wageningen UR Livestock Research, rapportnummer 449.

Hoving, I.E., P. Vereijken, K. van Houwelingen, M. Pleijter, 2013. Hydrologische en landbouwkundige effecten toepassing onderwaterdrains bij dynamisch slootpeilbeheer op veengrond. Wageningen UR Livestock Research, rapportnummer 719.

Hoving, I.E., H. Massop, K. van Houwelingen, J.J.H. van den Akker en J. Kollen, 2015. Hydrologische en landbouwkundige effecten toepassing onderwaterdrains in polder Zeevang; Vervolgonderzoek gericht op de toepassing van een zomer- en winterpeil. Wageningen, Wageningen UR (University \& Research centre) Livestock Research, Livestock Research Rapport 875.

Smolders, A., L. Lamers, E. Lucassen and J. Roelofs, 2006. Internal eutrophication: how it works and what to do about it - a review. Chemistry \& Ecology, nr. 22, pag. 93-111.

STOWA, 2015. http://deltaproof.stowa.nl/Publicaties/deltafact/Onderwaterdrains.aspx?pId=71

Wijk, A.L.M. van, 1988. Drainage, bearing capacity and yield (losses) on low moor peat pas-tures soils in The Netherlands. ICW-rapporten 20, 15 pp. 


\section{Bijlage 1 Boringen Wormer- en Jisperveld}

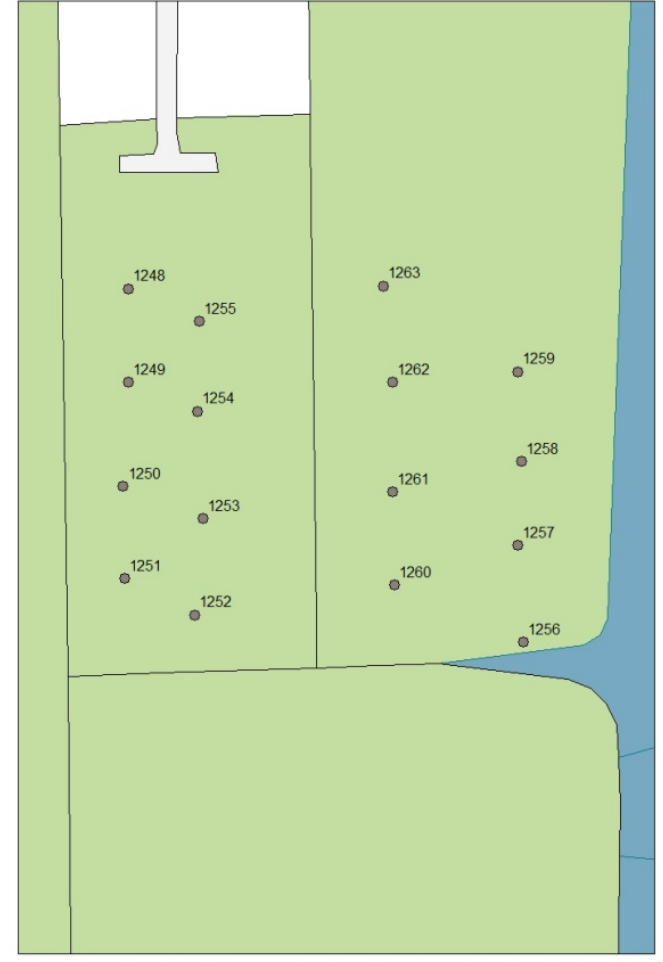

Figuur 1-1 Boringen in de percelen 5 en 6 (primaire locatie).

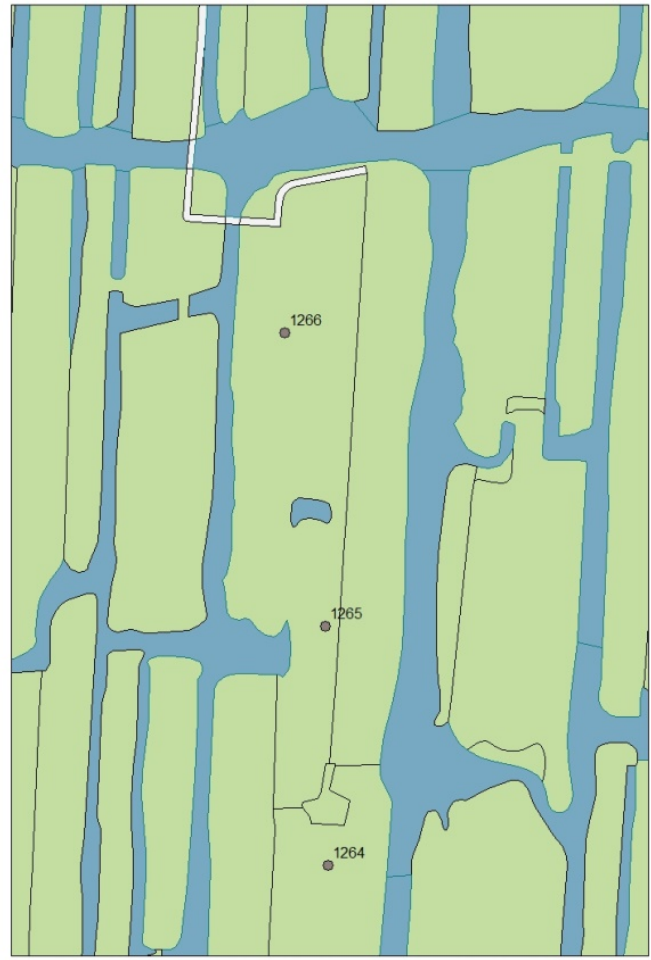

Figuur 1-2 Boringen in de percelen 1 - 4 (secudaire locatie).

Tabel 1-1 Overzichtstabel met boorpunten primaire en secundaire locatie (zie Figuren 1-1 en 1-2). Boringen zijn uitgevoerd op 24 nov 2011 door M. Pleijter. Details: zie Tabel 1-2.

\begin{tabular}{|cccccccc|}
\hline $\begin{array}{c}\text { Boorpunt } \\
\text { BPK_ID }\end{array}$ & X-coord. & Y-coord. & $\begin{array}{c}\text { HOOGTE (uit } \\
\text { AHN, in m NAP) }\end{array}$ & $\begin{array}{c}\text { GHG } \\
\text { (cm) }\end{array}$ & $\begin{array}{c}\text { GLG } \\
\text { (cm) }\end{array}$ & $\begin{array}{c}\text { GT_Code } \\
\text { Bew-diepte } \\
\text { (cm) }\end{array}$ \\
\hline 1248 & 116917,874 & 501328,266 & $-1,540$ & 0 & 65 & Ila & 25 \\
1249 & 116917,874 & 501303,417 & $-1,500$ & 0 & 65 & Ila & 30 \\
1250 & 116916,494 & 501275,807 & $-1,550$ & 0 & 65 & Ila & 25 \\
1251 & 116916,954 & 501251,418 & $-1,590$ & 0 & 65 & Ila & 30 \\
1252 & 116935,361 & 501241,755 & $-1,570$ & 0 & 65 & Ila & 30 \\
1253 & 116937,649 & 501267,317 & $-1,600$ & 0 & 65 & Ila & 30 \\
1254 & 116936,225 & 501295,792 & $-1,520$ & 0 & 70 & Ila & 20 \\
1255 & 116936,700 & 501319,521 & $-1,490$ & 0 & 65 & Ila & 30 \\
1256 & 117022,599 & 501234,571 & $-1,440$ & 15 & 50 & Ila & 35 \\
1257 & 117021,175 & 501260,198 & $-1,460$ & 0 & 55 & Ila & 25 \\
1258 & 117022,124 & 501282,504 & $-1,450$ & 0 & 55 & Ila & 30 \\
1259 & 117021,175 & 501306,233 & $-1,530$ & 0 & 55 & Ila & 30 \\
1260 & 116988,429 & 501249,758 & $-1,420$ & 0 & 65 & Ila & 40 \\
1261 & 116987,955 & 501274,436 & $-1,500$ & 0 & 60 & Ila & 30 \\
1262 & 116987,955 & 501303,385 & $-1,520$ & 0 & 60 & Ila & 30 \\
1263 & 116985,582 & 501329,012 & $-1,500$ & 0 & 60 & Ila & 30 \\
1264 & 117724,268 & 500616,454 & $-1,390$ & 0 & 65 & Ila & 25 \\
1265 & 117721,984 & 500817,504 & $-1,440$ & 10 & 60 & Ila & 45 \\
1266 & 117688,144 & 501064,507 & $-1,320$ & 0 & 65 & Ila & 25 \\
\hline
\end{tabular}


Tabel 1-2 Detailtabel met boorpunten en laagbeschrijvingen van de primaire en secundaire locaties Boringen zijn uitgevoerd op 24 nov 2011 door M. Pleijter. Overzichtstabel: zie Tabel 1-1.

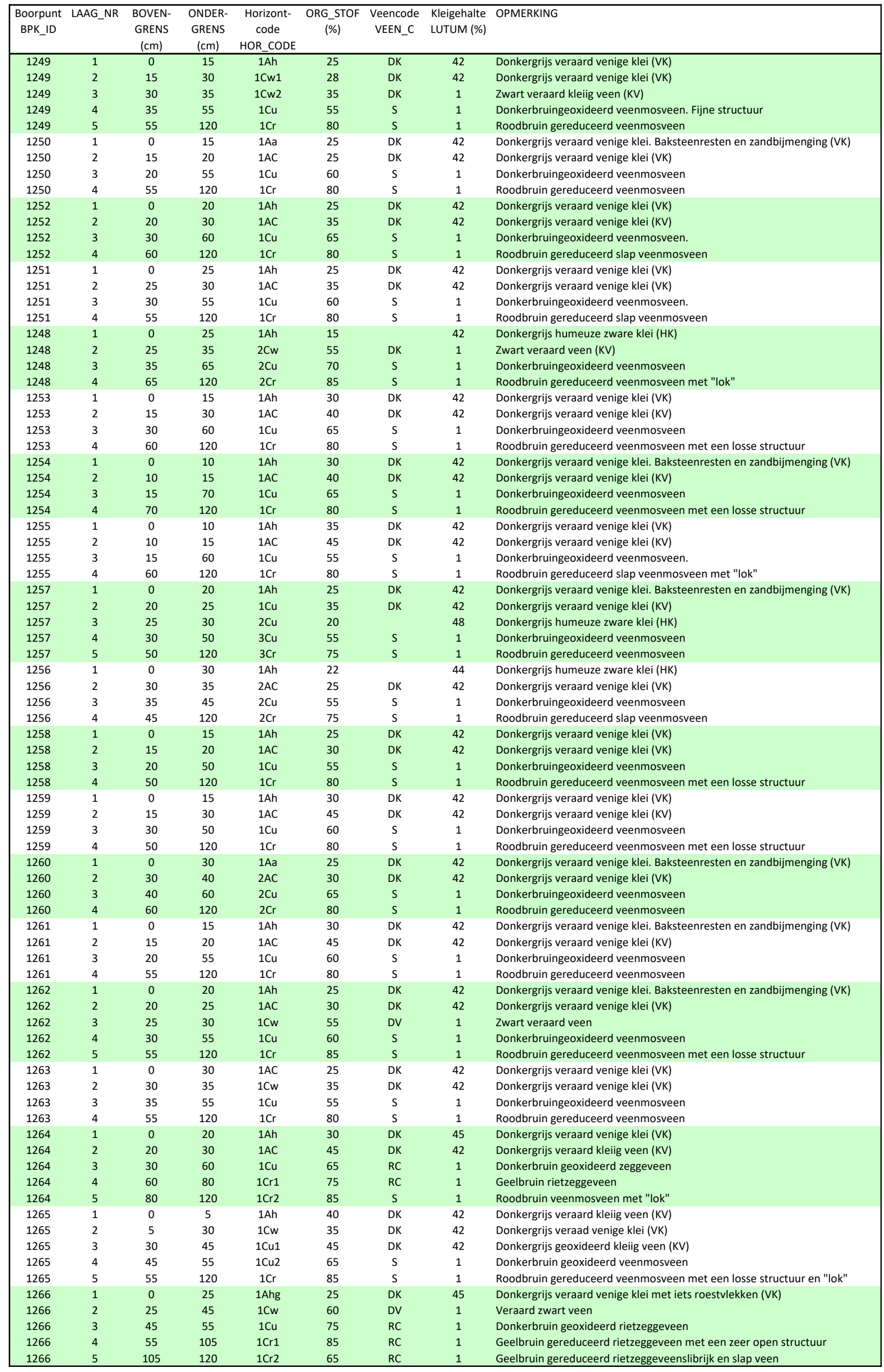




\section{Bijlage 2 Metingen doorlatendheden en berekening drainafstanden}

Drainageadvies Locatie dhr. Klaver, Dorpstraat te Wormer in het Wormer en Jisperveld Harry Massop en Martin Mulder

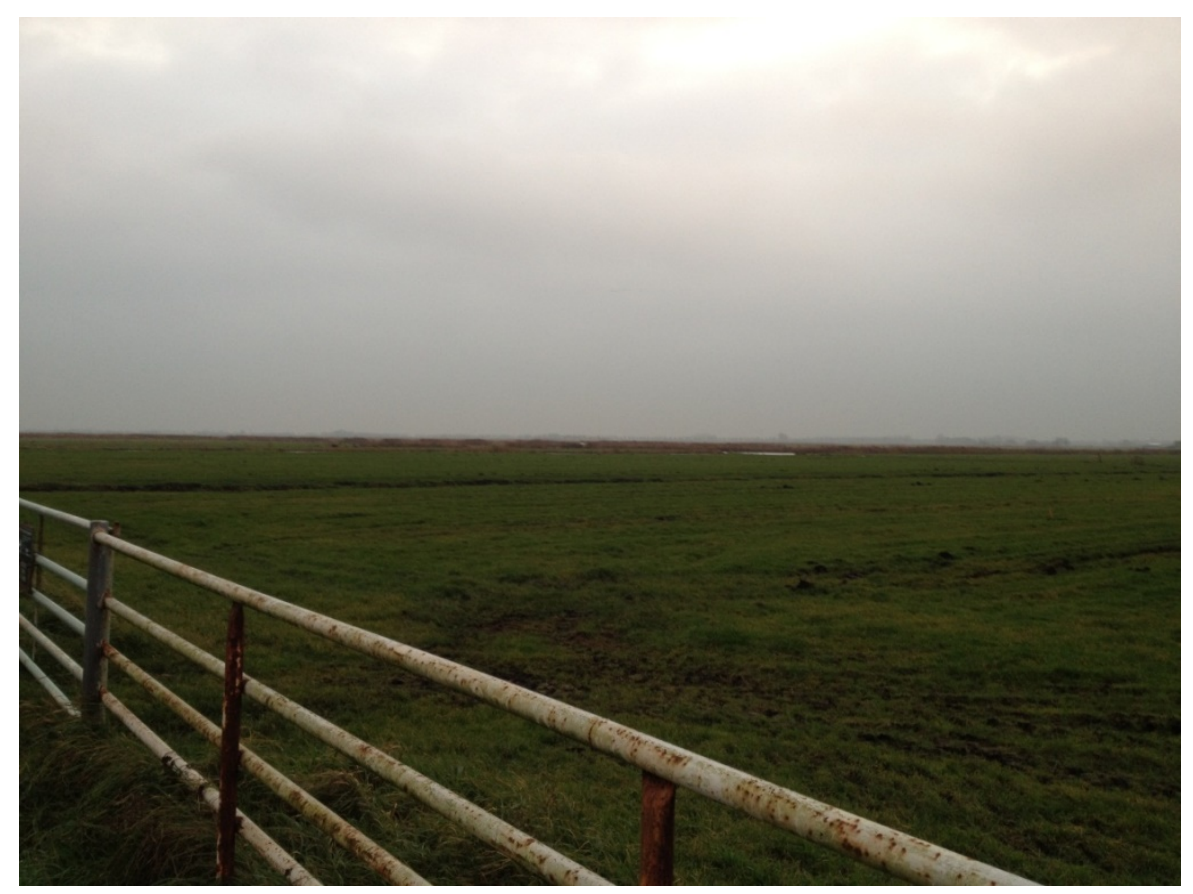

Figuur 2-1 Locatie perceel 5 vanuit de Mariastraat in Wormer ('s ochtends).

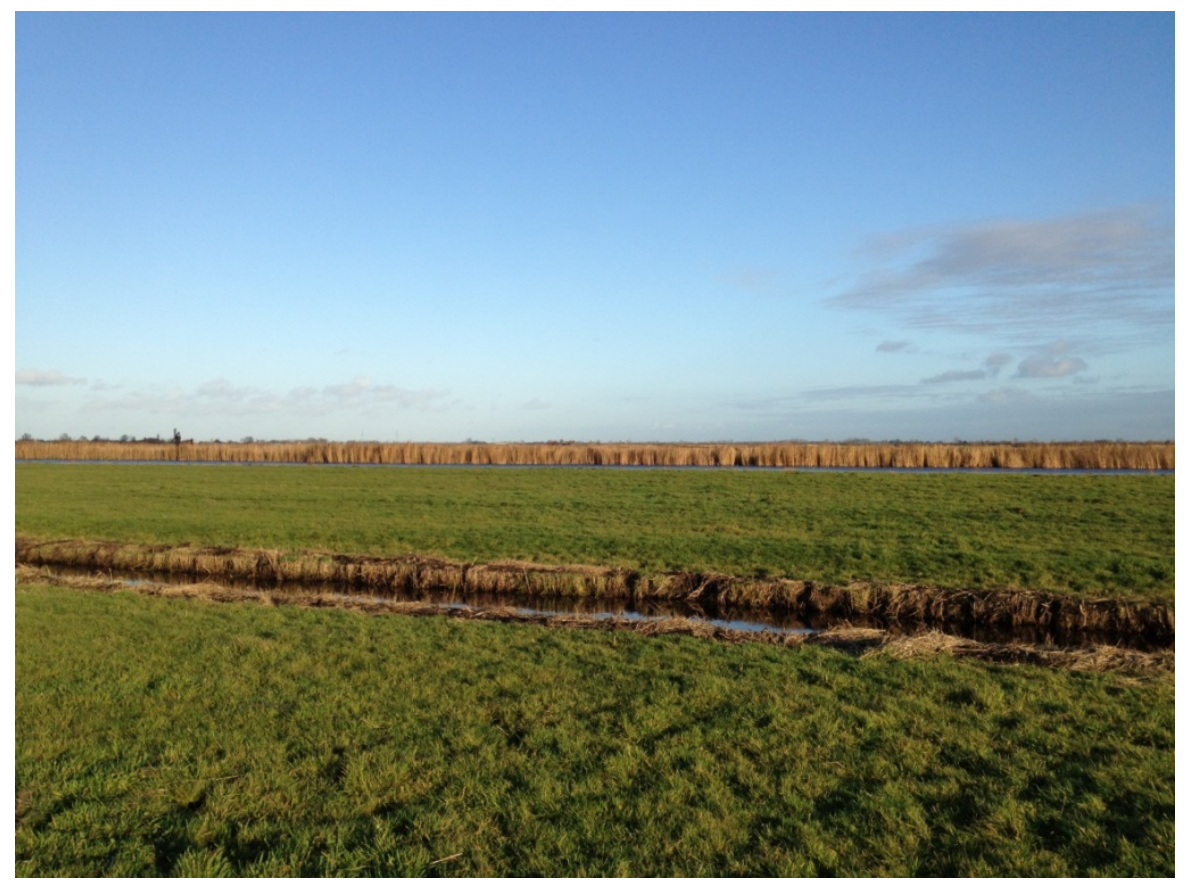

Figuur 2-2 Locatie perceel 4 ('s middags). 


\section{Boorgatmetingen}

Op 25 november 2011 zijn boorgatmetingen verricht op 3 percelen gelegen in het Wormer- en Jisperveld. In Figuur 3 is de ligging van de percelen weergegeven. Perceel 5 ligt ten westen van perceel 6.

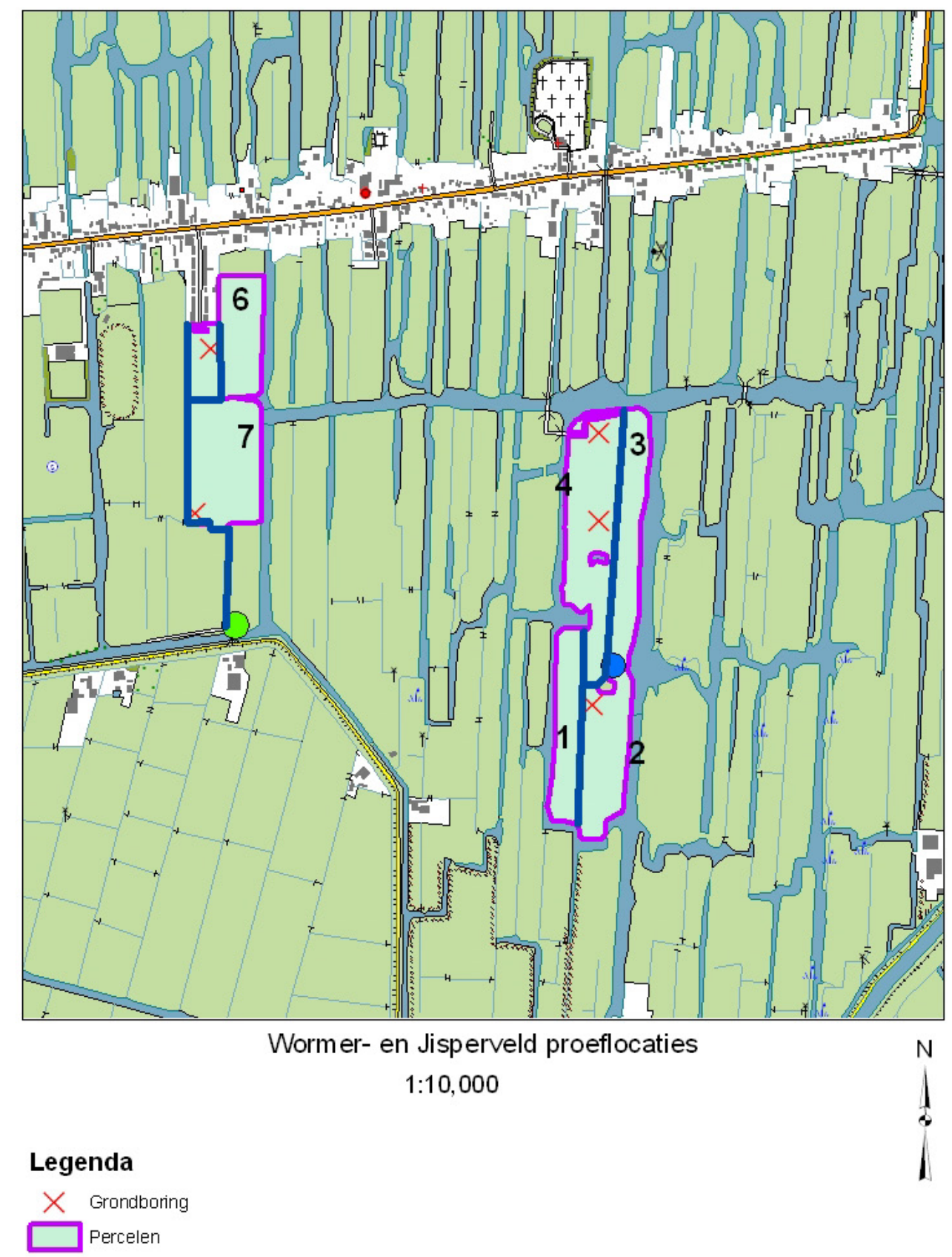

Figuur 2-3 Locatie percelen.

Op 12 locaties zijn boorgatmetingen verricht, zie Figuur 2-4, de locaties zijn aangeduid met de letter L. De metingen zijn uitgevoerd in de buurt van 6 van de boringen die zijn aangegeven in Bijlage 1 . 


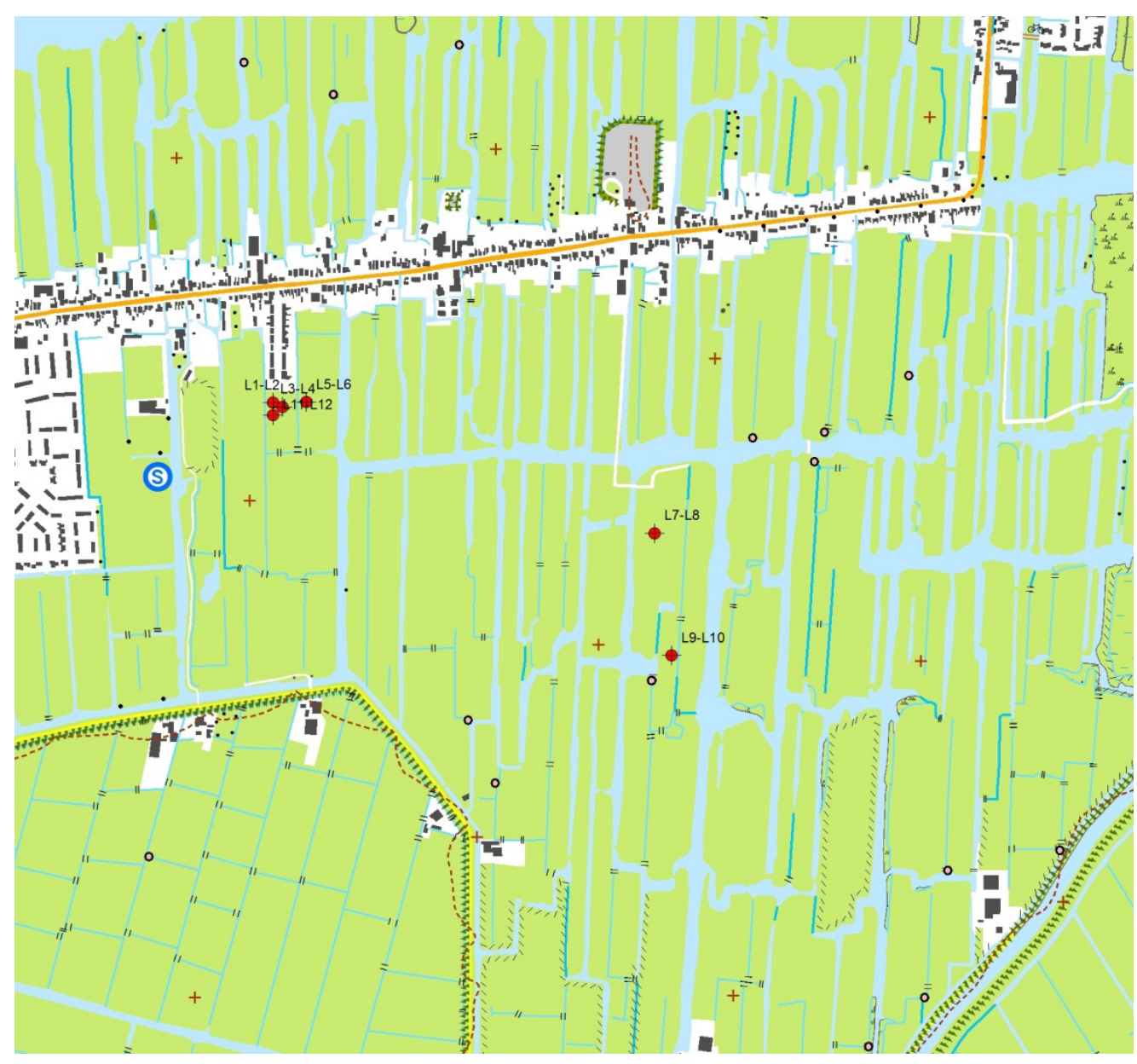

Figuur 2-4 Locaties boorgatmetingen.

Voorafgaand aan de metingen zijn op 24 november een aantal boorgaten gemaakt op de percelen 2 , 4, 5 en 6 om het bodemprofiel op te nemen (Bijlage 1) en om de uitgangsgrondwaterstand goed vast te leggen voor de boorgatenmethode. Bij zes van deze boorgaten zijn boorgatmetingen uitgevoerd, door steeds op korte afstand 2 boorgaten te maken en daarin metingen te verrichten. Bij het boren en daarna het meten van de grondwaterstand bleek dat het uiteindelijke boorgat kleiner is dan de diameter van de boor en dat daardoor de vlotter niet soepel in het boorgat kon bewegen; daarom is besloten om niet met een open boorgat te werken, maar met een filter $(r=4 \mathrm{~cm})$ in het boorgat. Ook bleek dat de boordiepte bij peiling geringer is dan verwacht op basis van de boordiepte. Om effecten van onnauwkeurigheid in de metingen op de resultaten inzichtelijk te maken, is een gevoeligheidsanalyse uitgevoerd. In Tabel 2-1 zijn de resultaten van de metingen weergegeven. Op locatie 7 en 8 zijn duidelijk hogere doorlatendheden gemeten dan op de overige locaties, nl. ca. $25 \mathrm{~cm} / \mathrm{d}$, dit betreft een andere veensoort. Op de meeste locaties is gemeten in veenmosveen, de $\mathrm{k}$-waarde varieert van $1,6-3,9 \mathrm{~cm} / \mathrm{d}$ met een uitschieter van $7,9 \mathrm{~cm} / \mathrm{d}$. 
Tabel 2-1 Resultaten boorgatmetingen Wormer- en Jisperveld.

\begin{tabular}{|l|c|c|c|}
\hline \multicolumn{1}{|c|}{ Locatie } & veld & $\mathbf{k}_{\text {gem }}$ & $\mathbf{k}_{\text {stdev }}$ \\
\hline L1 & & $\mathrm{m} / \mathrm{d}$ & $\mathrm{m} / \mathrm{d}$ \\
\hline L2 & 5 & 0.029 & 0.0111 \\
\hline L3 & 5 & 0.024 & 0.0085 \\
\hline L4 & 5 & 0.019 & 0.0066 \\
\hline L5 & 6 & 0.018 & 0.0060 \\
\hline L6 & 6 & 0.079 & 0.0120 \\
\hline L7 & 4 & 0.257 & 0.0185 \\
\hline L8 & 2 & 0.235 & 0.0208 \\
\hline L9 & 2 & 0.024 & 0.0085 \\
\hline L10 & 5 & 0.039 & 0.0037 \\
\hline L11 & 5 & 0.035 & 0.0072 \\
\hline L12 & veld 5 & 0.026 & 0.0036 \\
\hline & veld 6 & 0.049 & \\
\hline & veld 2 en 4 & 0.139 & \\
\hline & Gemiddeld & 0.067 & \\
\hline & & & \\
\hline
\end{tabular}

In Tabel 2-2 zijn de resultaten van de gevoeligheidsanalyse weergegeven.

Tabel 2-2 Resultaten gevoeligheidsanalyse.

\begin{tabular}{|c|c|c|c|c|c|c|c|c|c|c|}
\hline Locatie & veld & \multicolumn{9}{|c|}{$k$-waarde in $\mathrm{m} / \mathrm{d}$} \\
\hline L1 & 5 & 0.029 & 0.024 & 0.035 & 0.031 & 0.027 & 0.028 & 0.031 & 0.035 & 0.024 \\
\hline L2 & 5 & 0.016 & 0.013 & 0.020 & 0.017 & 0.016 & 0.015 & 0.018 & 0.020 & 0.013 \\
\hline L3 & 5 & 0.024 & 0.019 & 0.028 & 0.025 & 0.022 & 0.022 & 0.025 & 0.028 & 0.019 \\
\hline L4 & 5 & 0.019 & 0.016 & 0.023 & 0.021 & 0.018 & 0.018 & 0.020 & 0.023 & 0.016 \\
\hline L6 & 6 & 0.079 & 0.065 & 0.095 & 0.085 & 0.075 & 0.075 & 0.084 & 0.095 & 0.065 \\
\hline L7 & 4 & 0.257 & 0.209 & 0.308 & 0.281 & 0.239 & 0.246 & 0.270 & 0.308 & 0.209 \\
\hline L8 & 4 & 0.235 & 0.192 & 0.280 & 0.259 & 0.217 & 0.224 & 0.248 & 0.280 & 0.192 \\
\hline L9 & 2 & 0.024 & 0.020 & 0.029 & 0.026 & 0.022 & 0.023 & 0.025 & 0.029 & 0.020 \\
\hline \multirow[t]{5}{*}{ L12 } & 5 & 0.031 & 0.025 & 0.038 & 0.033 & 0.030 & 0.030 & 0.033 & 0.038 & 0.025 \\
\hline & veld 5 & 0.026 & 0.021 & 0.031 & 0.027 & 0.025 & 0.024 & 0.028 & 0.031 & 0.021 \\
\hline & veld 6 & 0.049 & 0.040 & 0.058 & 0.053 & 0.046 & 0.046 & 0.052 & 0.058 & 0.040 \\
\hline & veld 2,4 & 0.139 & 0.113 & 0.166 & 0.152 & 0.129 & 0.133 & 0.146 & 0.166 & 0.113 \\
\hline & Gemiddeld & 0.067 & 0.055 & 0.080 & 0.073 & 0.063 & 0.064 & 0.071 & 0.080 & 0.055 \\
\hline
\end{tabular}

${ }^{1} \mathrm{r}$ is straal boorgat in $\mathrm{cm}$

${ }^{2} \mathrm{Hi}$ initiële grondwaterstand in $\mathrm{cm}-\mathrm{mv}$

${ }^{3} \mathrm{H}$ boorgatdiepte in $\mathrm{cm}$

In Figuur 2-5 is de referentiewaarde en de minimum en maximum k-waarde uit de gevoeligheidsanalyse weergegeven. De waarden voor het veenmosveen zijn weinig gevoelig voor meetfouten in diameter, initiële grondwaterstand en boorgatdiepte in tegenstelling tot locatie 7 en 8 . 


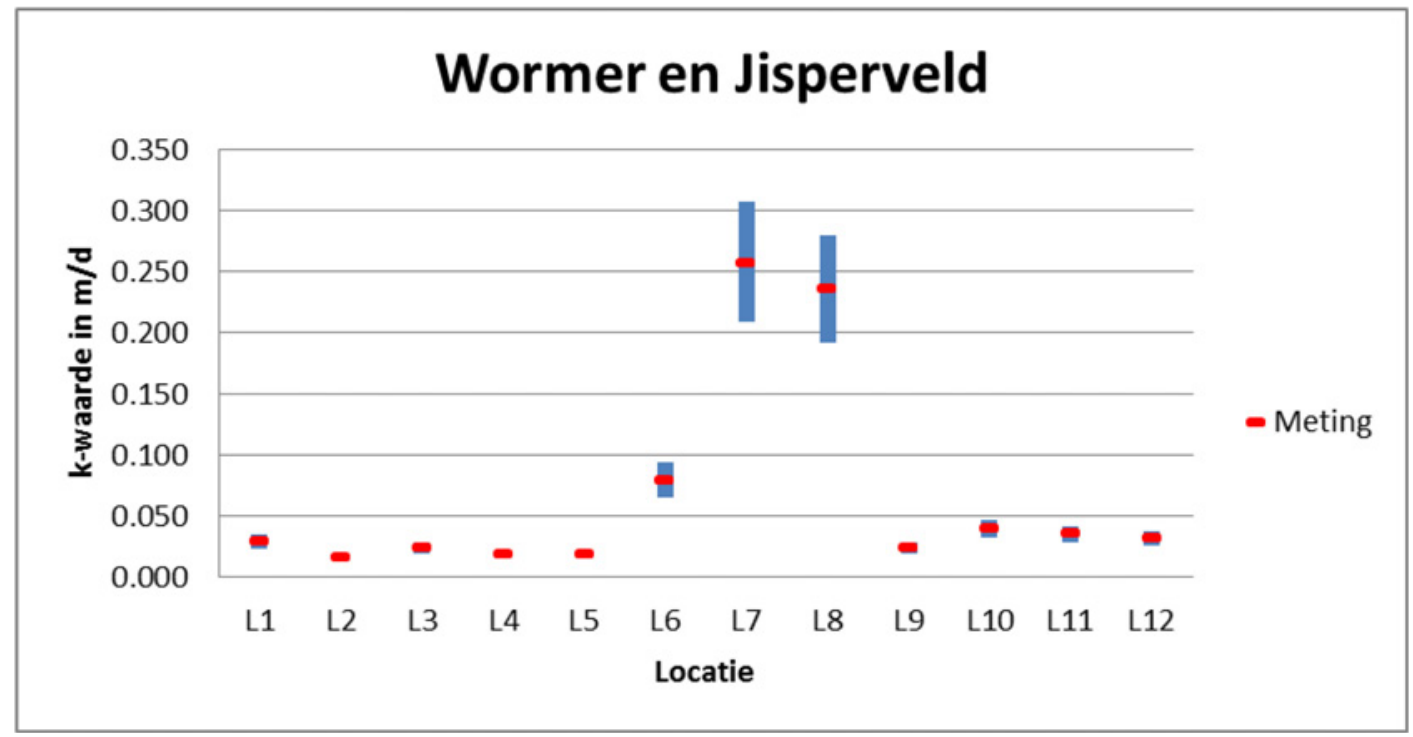

Figuur 2-5 Gemeten k-waarde en gevoeligheid voor meetfouten.

Om een inschatting te maken van de diepere ondergrond zijn enkele diepere boringen in de omgeving van de meetlocaties geselecteerd (Figuur 2-6).

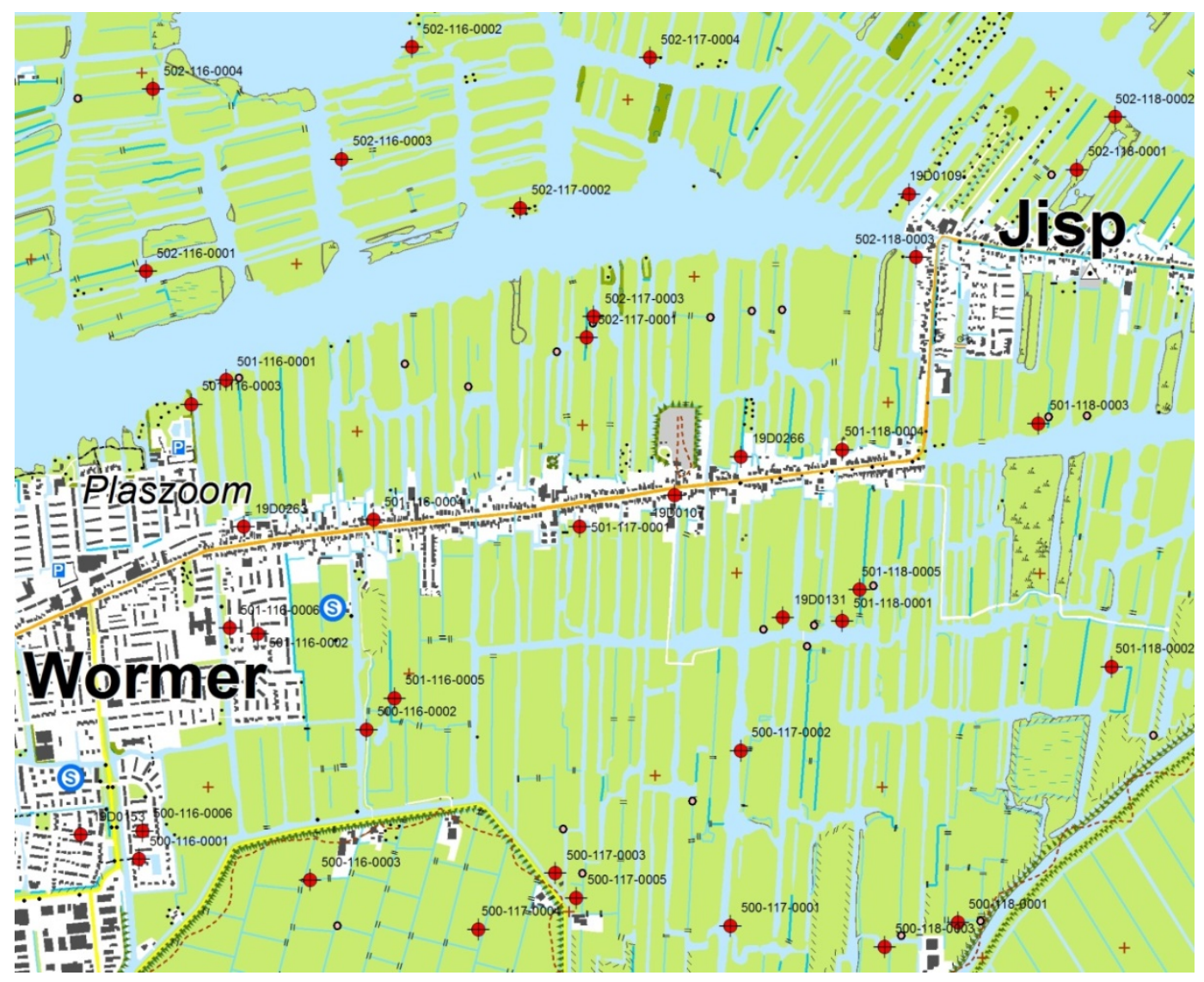

Figuur 2-6 Locatie van diepere boringen.

In Figuur 2-7 zijn 4 boringen in de omgeving van de meetlocatie weergegeven. 


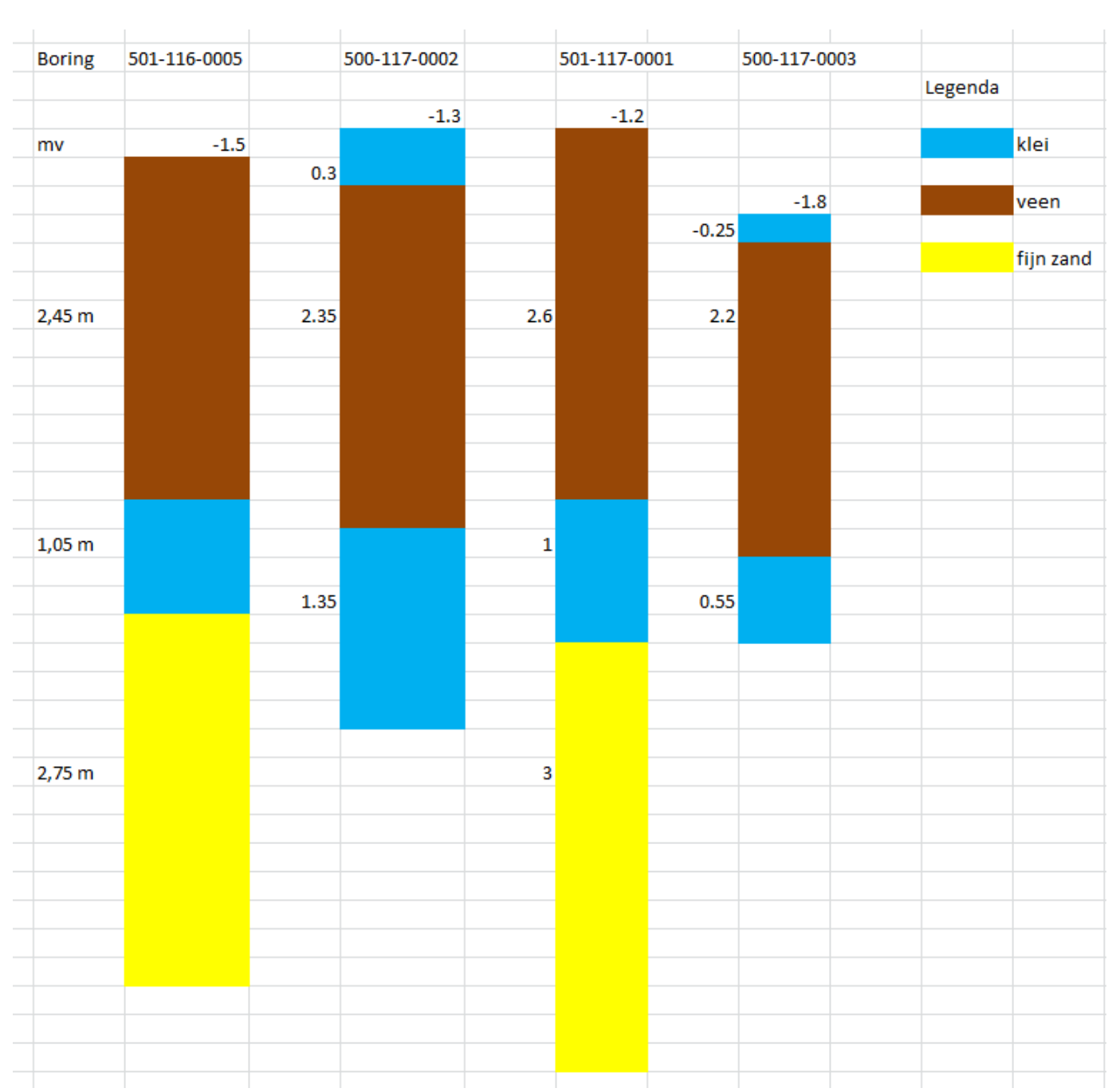

Figuur 2-7 Opbouw ondergrond van 4 boringen in de omgeving van de meetlocatie.

De bodemopbouw is als volgt: soms komt een dun kleidekje voor aan maaiveld van ca. $25-30 \mathrm{~cm}$. Uit de boorbeschrijvingen in Bijlage 1 blijkt dat een $20 \mathrm{~cm}$ dikke kleilaag op de onderzochte percelen voorkomt. Daaronder komt een veenlaag voor, in dikte variërend van 2,2-2,6 m. Daaronder ligt een kleilaag van min. $1 \mathrm{~m}$ overgaand in fijn zand. Uit de boorbeschrijving blijkt dat de veenlaag ca. 2,4 m dik is en ca. $2 \mathrm{~m}$-mv hoofdzakelijk uit veenmosveen bestaat, overgaand in rietzeggeveen (ca. $60 \mathrm{~cm}$ dik). Deze laag gaat over in een kleilaag.

\section{Drainageadvies}

Eisen: Uitholling $(\mathrm{m}) \max .10 \mathrm{~cm}$

Infiltratie dient de verdamping te compenseren, verdamping maximaal $5 \mathrm{~mm} / \mathrm{d}$, gemiddeld over een decade lijkt een aanvulling van $3 \mathrm{~mm} / \mathrm{d}$ (verdamping - neerslag-berging) een redelijke aanname.

Verdere aannamen: $\quad D=2,4 \mathrm{~m}$ (dikte veenlaag)

$\mathrm{k}_{1}=0,035 \mathrm{~m} / \mathrm{d}$ (veenmosveen boven de drains, gemiddelde perceel 2, 4 en 6 )

$\mathrm{k}_{2}=0,035 \mathrm{~m} / \mathrm{d}$ (veenmosveen onder de drains, gemiddelde perceel 2, 4 en 6 )

De formule van Hooghoudt toegepast op een infiltratiesituatie, d.w.z. omgekeerde drainage. Hierbij dient te worden opgemerkt dat de formule van Hooghoudt bij voorkeur wordt toegepast als de doorlatendheid van de bovenste laag groter is of gelijk is aan die van de onderste laag, hetgeen we hier aannemen.

De dikte van de equivalentlaag $d$ is te bepalen met:

$$
d=\frac{D}{1+\frac{8 D}{\pi L} \operatorname{Ln} \frac{D}{\pi r}}
$$


De drainafstand $(L)$ in relatie tot opbolling $(m)$ en infiltratie $(q)$ is te bepalen met:

$$
L^{2}=\frac{8 k_{2} d m+4 k_{1} m^{2}}{q}
$$

Voor diameters van 50,60, 80 en $100 \mathrm{~mm}$ en voor drainafstanden variërend van 4-15 is de equivalentlaagdikte berekend (Figuur 2-8). De dikte van de equivalentlaag is in de orde van $0,6-1,4$ afhankelijk van de drainafstand en diameter.

\section{Drainafstand $(\mathrm{m})$}

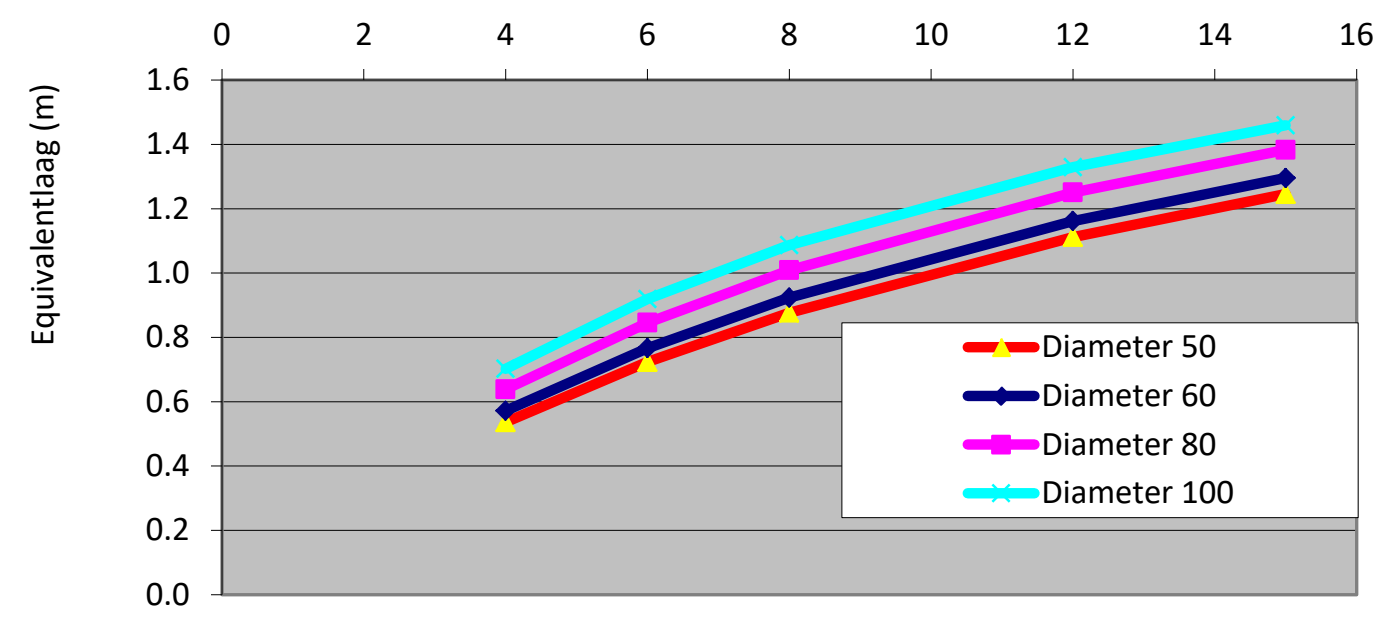

Figuur 2-8 Dikte equivalentlaag bij verschillende drainafstanden en draindiameters.

De relatie tussen infiltratie en drainafstand voor verschillende draindiameters is weergegeven in Figuur 2-9. Gezien de geringe k-waarde is de infiltratie beperkt. Om te kunnen voldoen aan een infiltratie van $3 \mathrm{~mm} / \mathrm{d}$, kunnen verschillende combinatie van drainafstand en uitholling worden beproefd. De relatie tussen infiltratie en drainafstand voor verschillende draindiameters bij een uitholling van $25 \mathrm{~cm}$ is weergegeven in Figuur 2-9.

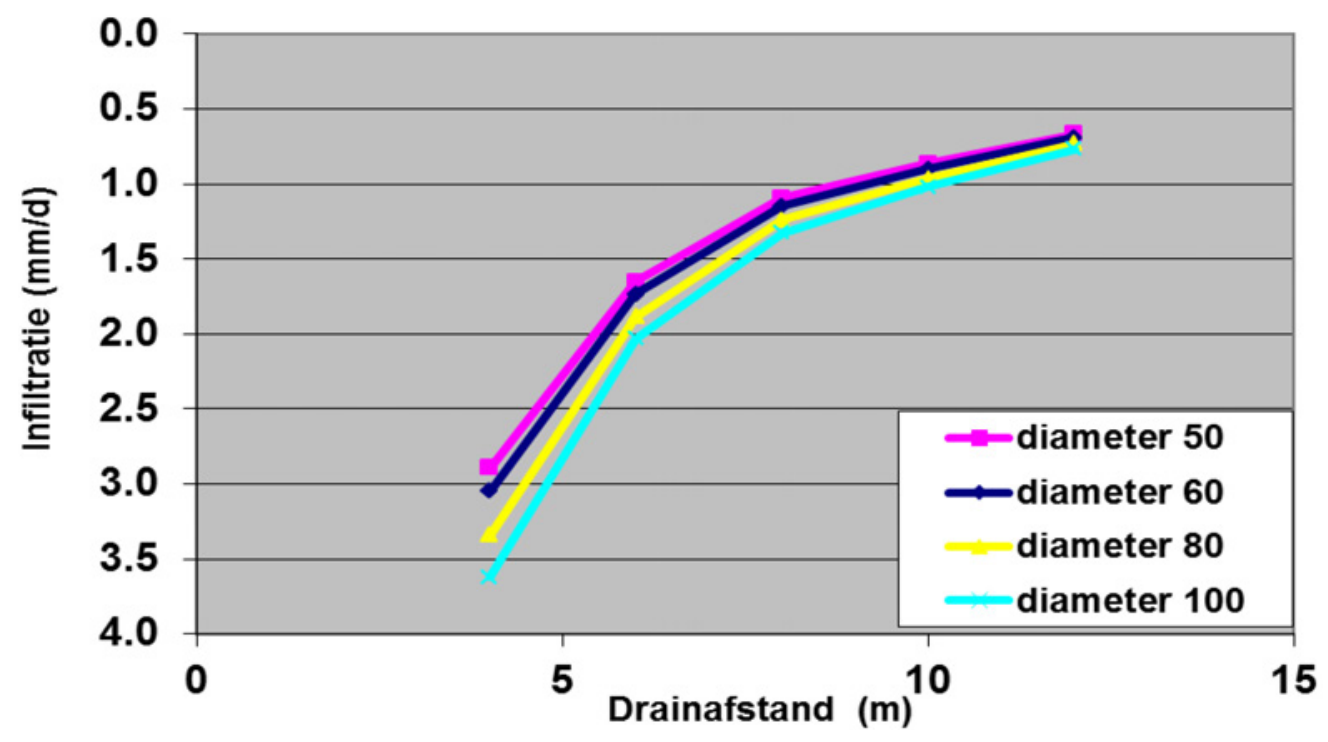

Figuur 2-9 Relatie tussen infiltratie en drainafstand bij verschillende draindiameters. 
Een uitholling van $20 \mathrm{~cm}$ is te gering om een infiltratie van $3 \mathrm{~mm} / \mathrm{d}$ te realiseren. Een uitholling van $30 \mathrm{~cm}$ voldoet ruimschoots en kan toegepast worden met een enigszins grotere drainafstand. Een infiltratie van $5 \mathrm{~mm} / \mathrm{d}$ lijkt moeilijk te realiseren. Om een infiltratie van $3 \mathrm{~mm} / \mathrm{d}$ te realiseren, dienen dus relatief korte drainafstanden te worden gehanteerd. Uitgaande van een infiltratie van $3 \mathrm{~mm} / \mathrm{d}$ en een maximale uitholling van $25 \mathrm{~cm}$, zou een drainafstand van ca. $4 \mathrm{~m}$ dienen te worden gehanteerd bij draindiameters van 60-80 mm. Hierbij zouden de drains op 70-80 cm -mv kunnen worden gelegd. Bij de kartering is de drooglegging/waterpeil van $20 \mathrm{~cm}-\mathrm{mv}$ geschat. De drooglegging in veengebieden is meestal wat dieper, ca. $40 \mathrm{~cm}-\mathrm{mv}$. In de winter staat de grondwaterstand in het maaiveld en wordt een deel van het neerslagoverschot via maaiveldgreppels afgevoerd.

\section{Conclusies}

- De gevonden k-waarde voor veenmosveen is relatief laag; als gemiddelde voor de berekeningen met Hooghoudt is $3,5 \mathrm{~cm} / \mathrm{d}$ aangehouden.

- Bij toepassing van onderwaterdrainage geeft de formule van Hooghoudt aan dat: uitgaande van een benodigde infiltratie van $3 \mathrm{~mm} / \mathrm{d}$ en een maximale uitholling van $25 \mathrm{~cm}$ een drainafstand van $4 \mathrm{~m}$ zal voldoen, voor verschillende draindiameters van 60-80 $\mathrm{mm}$. Hierbij zouden de drains op 70-80 cm-mv kunnen worden gelegd bij een waterpeil van 20-40 cm -mv.

- Aan de vooraf gestelde eis van maximale uitholling van $10 \mathrm{~cm}$ kan niet worden voldaan.

- Door het hoge ontwateringsniveau kunnen grondwaterstanden tot in maaiveld voorkomen. De maaiveldafvoer wordt bevorderd door het bol leggen van het perceel. Ook bij toepassing van buisdrainage is bol leggen van het perceel aan te bevelen, met maaiveldgreppels boven de drains. 


\section{Bijlage 3 Meetresultaten draagkracht, indringweerstanden en grashoogten}

In de Tabellen 3-1, 3-2, 3-3, 3-4, 3-5 en 3-6 zijn de resultaten van de draagkrachtmetingen, indringweerstanden en grashoogten verzameld.

Tabel 3-1 Draagkrachtmetingen in 2013 met een conus van $5 \mathrm{~cm}^{2}$. Gemiddelden (Gem) en standaarddeviatie (SD) van 20 metingen per perceeldeel met of zonder drains uitgedrukt in MPa. Aantal ( $n$ ) metingen per perceeldeel met een draagkracht $>0,5 \mathrm{MPa}$ en dit aantal $n$ uitgedrukt als percentage van de 20 metingen per perceeldeel. Idem voor een draagkracht $>0,6 \mathrm{MPa}$.

\begin{tabular}{|c|c|c|c|c|c|c|c|}
\hline Gem (MPa) & 9-4-2013 & $18-4-2013$ & $25-4-2013$ & 3-5-2013 & $10-5-2013$ & 24-5-2013 & $31-5-2013$ \\
\hline Referentie 5 & 0.43 & 0.51 & 0.68 & 0.75 & 0.91 & 0.65 & 0.68 \\
\hline Drains 5 & 0.59 & 0.48 & 0.89 & 0.93 & 0.91 & 0.66 & 0.63 \\
\hline Referentie 6 & 0.39 & 0.39 & 0.56 & 0.77 & 0.73 & 0.61 & 0.57 \\
\hline Drains 6 & 0.39 & 0.36 & 0.67 & 0.69 & 0.90 & 0.56 & 0.60 \\
\hline SD (MPa) & 9-4-2013 & $18-4-2013$ & $25-4-2013$ & 3-5-2013 & $10-5-2013$ & $24-5-2013$ & $31-5-2013$ \\
\hline Referentie 5 & 0.22 & 0.15 & 0.24 & 0.40 & 0.34 & 0.25 & 0.28 \\
\hline Drains 5 & 0.21 & 0.21 & 0.27 & 0.35 & 0.51 & 0.30 & 0.30 \\
\hline Referentie 6 & 0.19 & 0.16 & 0.29 & 0.36 & 0.42 & 0.24 & 0.20 \\
\hline Drains 6 & 0.15 & 0.20 & 0.30 & 0.31 & 0.32 & 0.17 & 0.30 \\
\hline
\end{tabular}

\begin{tabular}{|c|c|c|c|c|c|c|c|}
\hline$n>0,5$ & $9-4-2013$ & $18-4-2013$ & 25-4-2013 & 3-5-2013 & $10-5-2013$ & $24-5-2013$ & $31-5-2013$ \\
\hline Referentie 5 & 9 & 12 & 17 & 14 & 17 & 15 & 15 \\
\hline Drains 5 & 14 & 9 & 18 & 18 & 16 & 14 & 15 \\
\hline Referentie 6 & 9 & 4 & 12 & 15 & 11 & 13 & 12 \\
\hline Drains 6 & 8 & 3 & 14 & 15 & 18 & 14 & 14 \\
\hline
\end{tabular}

\begin{tabular}{|c|c|c|c|c|c|c|c|}
\hline$n>0,5(\%)$ & $9-4-2013$ & $18-4-2013$ & $25-4-2013$ & 3-5-2013 & $10-5-2013$ & $24-5-2013$ & $31-5-2013$ \\
\hline Referentie 5 & 45 & 60 & 85 & 70 & 85 & 75 & 75 \\
\hline Drains 5 & 70 & 45 & 90 & 90 & 80 & 70 & 75 \\
\hline Referentie 6 & 45 & 20 & 60 & 75 & 55 & 65 & 60 \\
\hline Drains 6 & 40 & 15 & 70 & 75 & 90 & 70 & 70 \\
\hline
\end{tabular}

\begin{tabular}{|c|c|c|c|c|c|c|c|}
\hline$n>0,6$ & $9-4-2013$ & $18-4-2013$ & 25-4-2013 & $3-5-2013$ & $10-5-2013$ & $24-5-2013$ & $31-5-2013$ \\
\hline Referentie 5 & 6 & 8 & 12 & 14 & 16 & 14 & 13 \\
\hline Drains 5 & 12 & 8 & 18 & 18 & 14 & 12 & 12 \\
\hline Referentie 6 & 3 & 2 & 10 & 14 & 11 & 9 & 9 \\
\hline Drains 6 & 3 & 2 & 13 & 14 & 17 & 9 & 13 \\
\hline
\end{tabular}

\begin{tabular}{|c|c|c|c|c|c|c|c|}
\hline$n>0,6(\%)$ & 9-4-2013 & $18-4-2013$ & 25-4-2013 & 3-5-2013 & $10-5-2013$ & 24-5-2013 & $31-5-2013$ \\
\hline Referentie 5 & 30 & 40 & 60 & 70 & 80 & 70 & 65 \\
\hline Drains 5 & 60 & 40 & 90 & 90 & 70 & 60 & 60 \\
\hline Referentie 6 & 15 & 10 & 50 & 70 & 55 & 45 & 45 \\
\hline Drains 6 & 15 & 10 & 65 & 70 & 85 & 45 & 65 \\
\hline
\end{tabular}


Tabel 3-2 Draagkrachtmetingen in $\mathbf{2 0 1 4}$ met een conus van $5 \mathrm{~cm}^{2}$. Gemiddelden (Gem) en standaarddeviatie (SD) van 20 metingen per perceeldeel met of zonder drains uitgedrukt in MPa. Aantal (n) metingen per perceeldeel met een draagkracht $>0,5 \mathrm{MPa}$ en dit aantal $n$ uitgedrukt als percentage van de 20 metingen per perceeldeel. Idem voor een draagkracht > 0,6 MPa.

\begin{tabular}{|c|c|c|c|c|c|c|}
\hline Gem (MPa) & $7-3-2014$ & $20-3-2014$ & 2-4-2014 & $16-4-2014$ & 2-5-2014 & $16-5-2014$ \\
\hline Referentie 3 & 0.24 & & 0.48 & 0.67 & 0.79 & 0.59 \\
\hline Drains 3 & 0.33 & & 0.67 & 0.68 & 0.76 & 0.67 \\
\hline Referentie 4 & 0.54 & & 0.78 & 0.85 & 0.85 & 0.75 \\
\hline Drains 4 & 0.57 & & 0.88 & 0.87 & 0.84 & 0.78 \\
\hline Referentie 5 & 0.40 & 0.58 & 0.57 & 0.74 & 0.72 & 0.64 \\
\hline Drains 5 & 0.46 & 0.70 & 0.67 & 0.84 & 0.84 & 0.69 \\
\hline Referentie 6 & 0.20 & 0.45 & 0.50 & 0.63 & 0.64 & 0.52 \\
\hline Drains 6 & 0.28 & 0.59 & 0.52 & 0.71 & 0.65 & 0.56 \\
\hline
\end{tabular}

\begin{tabular}{|c|c|c|c|c|c|c|}
\hline $\mathrm{SD}(\mathrm{MPa})$ & $7-3-2014$ & 20-3-2014 & 2-4-2014 & $16-4-2014$ & $2-5-2014$ & $16-5-2014$ \\
\hline Referentie 3 & 0.07 & & 0.21 & 0.24 & 0.23 & 0.20 \\
\hline Drains 3 & 0.11 & & 0.19 & 0.19 & 0.20 & 0.22 \\
\hline Referentie 4 & 0.17 & & 0.22 & 0.24 & 0.26 & 0.23 \\
\hline Drains 4 & 0.21 & & 0.20 & 0.23 & 0.25 & 0.25 \\
\hline Referentie 5 & 0.19 & 0.24 & 0.24 & 0.27 & 0.26 & 0.21 \\
\hline Drains 5 & 0.23 & 0.21 & 0.19 & 0.25 & 0.30 & 0.21 \\
\hline Referentie 6 & 0.03 & 0.11 & 0.16 & 0.22 & 0.21 & 0.14 \\
\hline Drains 6 & 0.11 & 0.18 & 0.14 & 0.24 & 0.20 & 0.11 \\
\hline
\end{tabular}

\begin{tabular}{|l|c|c|c|c|c|c|}
\hline \multicolumn{1}{|c}{$\mathbf{n}>\mathbf{0 , 5}$} & $\mathbf{7 - 3 - 2 0 1 4}$ & $\mathbf{2 0 - 3 - 2 0 1 4}$ & $\mathbf{2 - 4 - 2 0 1 4}$ & $\mathbf{1 6 - 4 - 2 0 1 4}$ & $\mathbf{2 - 5 - 2 0 1 4}$ & $\mathbf{1 6 - 5 - 2 0 1 4}$ \\
\hline Referentie 3 & 0 & & 7 & 14 & 20 & 12 \\
\hline Drains 3 & 3 & & 16 & 17 & 18 & 15 \\
\hline Referentie 4 & 12 & & 18 & 19 & 18 & 19 \\
\hline Drains 4 & 7 & & 20 & 20 & 19 & 18 \\
\hline Referentie 5 & 6 & 13 & 10 & 15 & 17 & 17 \\
\hline Drains 5 & 6 & 15 & 18 & 20 & 18 & 17 \\
\hline Referentie 6 & 0 & 7 & 10 & 17 & 17 & 11 \\
\hline Drains 6 & 0 & 13 & 10 & 16 & 15 & 13 \\
\hline
\end{tabular}

\begin{tabular}{|l|c|c|c|c|c|c|}
\hline \multicolumn{1}{|c|}{$\mathbf{n}>\mathbf{0 , 5}$ (\%) } & $\mathbf{7 - 3 - 2 0 1 4}$ & $\mathbf{2 0 - 3 - 2 0 1 4}$ & $\mathbf{2 - 4 - 2 0 1 4}$ & $\mathbf{1 6 - 4 - 2 0 1 4}$ & $\mathbf{2 - 5 - 2 0 1 4}$ & $\mathbf{1 6 - 5 - 2 0 1 4}$ \\
\hline Referentie 3 & 0 & & 35 & 70 & 100 & 60 \\
\hline Drains 3 & 15 & & 80 & 85 & 90 & 75 \\
\hline Referentie 4 & 60 & & 90 & 95 & 90 & 95 \\
\hline Drains 4 & 35 & & 100 & 100 & 95 & 90 \\
\hline Referentie 5 & 30 & 65 & 50 & 75 & 85 & 85 \\
\hline Drains 5 & 30 & 75 & 90 & 100 & 90 & 85 \\
\hline Referentie 6 & 0 & 35 & 50 & 85 & 85 & 55 \\
\hline Drains 6 & 0 & 65 & 50 & 80 & 75 & 65 \\
\hline
\end{tabular}

\begin{tabular}{|l|c|c|c|c|c|c|}
\hline \multicolumn{1}{|c}{$\mathbf{n}>\mathbf{0 , 6}$} & $\mathbf{7 - 3 - 2 0 1 4}$ & $\mathbf{2 0 - 3 - 2 0 1 4}$ & $\mathbf{2 - 4 - 2 0 1 4}$ & $\mathbf{1 6 - 4 - 2 0 1 4}$ & $\mathbf{2 - 5 - 2 0 1 4}$ & $\mathbf{1 6 - 5 - 2 0 1 4}$ \\
\hline Referentie 3 & 0 & & 6 & 12 & 18 & 9 \\
\hline Drains 3 & 0 & & 12 & 12 & 15 & 14 \\
\hline Referentie 4 & 7 & & 16 & 16 & 17 & 16 \\
\hline Drains 4 & 6 & & 19 & 17 & 18 & 14 \\
\hline Referentie 5 & 4 & 7 & 7 & 13 & 12 & 11 \\
\hline Drains 5 & 5 & 13 & 15 & 16 & 17 & 16 \\
\hline Referentie 6 & 0 & 3 & 6 & 11 & 11 & 9 \\
\hline Drains 6 & 0 & 9 & 6 & 12 & 11 & 8 \\
\hline
\end{tabular}

\begin{tabular}{llllllll}
$n>0,6$ & $(\%)$ & $7-3-2014$ & $20-3-2014$ & $2-4-2014$ & $16-4-2014$ & $2-5-2014$ & $16-5-2014$ \\
\hline
\end{tabular}

\begin{tabular}{|l|c|c|c|c|c|c|}
\hline Referentie 3 & 0 & & 30 & 60 & 90 & 45 \\
\hline Drains 3 & 0 & & 60 & 60 & 75 & 70 \\
\hline Referentie 4 & 35 & & 80 & 80 & 85 & 80 \\
\hline Drains 4 & 30 & & 95 & 85 & 90 & 70 \\
\hline Referentie 5 & 20 & 35 & 35 & 65 & 60 & 55 \\
\hline Drains 5 & 25 & 65 & 75 & 80 & 85 & 80 \\
\hline Referentie 6 & 0 & 15 & 30 & 55 & 55 & 45 \\
\hline Drains 6 & 0 & 45 & 30 & 60 & 55 & 40 \\
\hline
\end{tabular}


Tabel 3-3 Indringweerstanden in 2013 met een conus van $1 \mathrm{~cm}^{2}$. Gemiddelden (Gem) en standaarddeviatie (SD) van 20 metingen per perceeldeel met of zonder drains uitgedrukt in MPa. Aantal (n) metingen per perceeldeel van de 20 met een draagkracht $<0,25 \mathrm{MPa}$ en dit aantal $n$ uitgedrukt als percentage van de 20 metingen per perceeldeel.

\begin{tabular}{|c|c|c|c|c|c|c|c|}
\hline Gem (MPa) & $9-4-2013$ & $18-4-2013$ & $25-4-2013$ & $3-5-2013$ & $10-5-2013$ & 24-5-2013 & $31-5-2013$ \\
\hline Referentie 5 & 0.70 & 0.70 & 1.05 & 1.40 & 1.82 & 0.96 & 1.00 \\
\hline Drains 5 & 0.93 & 0.78 & 1.15 & 1.47 & 1.76 & 0.93 & 1.17 \\
\hline Referentie 6 & 0.64 & 0.54 & 0.96 & 1.21 & 1.57 & 0.84 & 0.92 \\
\hline Drains 6 & 0.62 & 0.73 & 0.90 & 1.14 & 1.44 & 0.82 & 0.98 \\
\hline
\end{tabular}

\begin{tabular}{|c|c|c|c|c|c|c|c|}
\hline $\mathrm{SD}(\mathrm{MPa})$ & 9-4-2013 & $18-4-2013$ & 25-4-2013 & $3-5-2013$ & $10-5-2013$ & 24-5-2013 & $31-5-2013$ \\
\hline Referentie 5 & 0.18 & 0.28 & 0.45 & 0.49 & 0.64 & 0.37 & 0.29 \\
\hline Drains 5 & 0.44 & 0.31 & 0.47 & 0.66 & 0.66 & 0.25 & 0.35 \\
\hline Referentie 6 & 0.23 & 0.25 & 0.37 & 0.38 & 0.56 & 0.23 & 0.28 \\
\hline Drains 6 & 0.23 & 0.35 & 0.29 & 0.34 & 0.42 & 0.22 & 0.26 \\
\hline
\end{tabular}

\begin{tabular}{lllllllll}
$n<0,25$ & $9-4-2013$ & $18-4-2013$ & $25-4-2013$ & $3-5-2013$ & $10-5-2013$ & $24-5-2013$ & $31-5-2013$ \\
\hline
\end{tabular}

\begin{tabular}{|l|l|l|l|l|l|l|l|}
\hline Referentie 5 & 0 & 0 & 0 & 0 & 0 & 0 & 0 \\
\hline Drains 5 & 0 & 1 & 0 & 0 & 0 & 0 & 0 \\
\hline Referentie 6 & 0 & 1 & 0 & 0 & 0 & 0 & 0 \\
\hline Drains 6 & 0 & 0 & 0 & 0 & 0 & 0 & 0 \\
\hline
\end{tabular}

\begin{tabular}{|c|c|c|c|c|c|c|c|}
\hline$n<0,25(\%)$ & $9-4-2013$ & $18-4-2013$ & $25-4-2013$ & $3-5-2013$ & $10-5-2013$ & $24-5-2013$ & $31-5-2013$ \\
\hline Referentie 5 & 0 & 0 & 0 & 0 & 0 & 0 & 0 \\
\hline Drains 5 & 0 & 5 & 0 & 0 & 0 & 0 & 0 \\
\hline Referentie 6 & 0 & 5 & 0 & 0 & 0 & 0 & 0 \\
\hline Drains 6 & 0 & 0 & 0 & 0 & 0 & 0 & 0 \\
\hline
\end{tabular}


Tabel 3-4 Indringweerstanden in 2014 met een conus van $1 \mathrm{~cm}^{2}$. Gemiddelden (Gem) en standaarddeviatie (SD) van 20 metingen per perceeldeel met of zonder drains uitgedrukt in MPa. Aantal (n) metingen per perceeldeel van de 20 met een draagkracht $<0,25 \mathrm{MPa}$ en dit aantal $n$ uitgedrukt als percentage van de 20 metingen per perceeldeel.

\begin{tabular}{|c|c|c|c|c|c|c|}
\hline Gem (MPa) & $7-3-2014$ & 20-3-2014 & $2-4-2014$ & $16-4-2014$ & 2-5-2014 & $16-5-2014$ \\
\hline Referentie 3 & 0.22 & & 0.54 & 0.64 & 0.72 & 0.64 \\
\hline Drains 3 & 0.33 & & 0.78 & 0.76 & 0.68 & 0.71 \\
\hline Referentie 4 & 0.61 & & 0.84 & 1.04 & 0.95 & 0.78 \\
\hline Drains 4 & 0.61 & & 1.00 & 0.98 & 0.91 & 0.85 \\
\hline Referentie 5 & 0.36 & 0.57 & 0.67 & 0.76 & 0.71 & 0.59 \\
\hline Drains 5 & 0.48 & 0.69 & 0.72 & 0.88 & 0.89 & 0.72 \\
\hline Referentie 6 & 0.33 & 0.47 & 0.53 & 0.52 & 0.56 & 0.50 \\
\hline Drains 6 & 0.41 & 0.68 & 0.57 & 0.66 & 0.59 & 0.60 \\
\hline
\end{tabular}

\begin{tabular}{|c|c|c|c|c|c|c|}
\hline SD (MPa) & $7-3-2014$ & $20-3-2014$ & $2-4-2014$ & $16-4-2014$ & 2-5-2014 & $16-5-2014$ \\
\hline Referentie 3 & 0.06 & & 0.24 & 0.28 & 0.29 & 0.42 \\
\hline Drains 3 & 0.19 & & 0.36 & 0.36 & 0.34 & 0.46 \\
\hline Referentie 4 & 0.31 & & 0.45 & 0.32 & 0.38 & 0.50 \\
\hline Drains 4 & 0.35 & & 0.35 & 0.34 & 0.37 & 0.28 \\
\hline Referentie 5 & 0.19 & 0.37 & 0.35 & 0.38 & 0.36 & 0.31 \\
\hline Drains 5 & 0.15 & 0.21 & 0.37 & 0.49 & 0.38 & 0.30 \\
\hline Referentie 6 & 0.19 & 0.30 & 0.29 & 0.29 & 0.30 & 0.33 \\
\hline Drains 6 & 0.15 & 0.34 & 0.32 & 0.28 & 0.29 & 0.42 \\
\hline
\end{tabular}

\begin{tabular}{|c|c|c|c|c|c|c|}
\hline$n<0,25$ & $7-3-2014$ & $20-3-2014$ & $2-4-2014$ & $16-4-2014$ & $2-5-2014$ & $16-5-2014$ \\
\hline Referentie 3 & 18 & & 4 & 2 & 0 & 3 \\
\hline Drains 3 & 12 & & 1 & 1 & 1 & 3 \\
\hline Referentie 4 & 4 & & 2 & 0 & 0 & 2 \\
\hline Drains 4 & 3 & & 0 & 0 & 1 & 0 \\
\hline Referentie 5 & 10 & 6 & 2 & 2 & 2 & 3 \\
\hline Drains 5 & 2 & 0 & 2 & 1 & 1 & 1 \\
\hline Referentie 6 & 10 & 8 & 5 & 5 & 2 & 7 \\
\hline Drains 6 & 5 & 2 & 3 & 1 & 3 & 4 \\
\hline
\end{tabular}

\begin{tabular}{|c|c|c|c|c|c|c|}
\hline$n<0,25(\%)$ & $7-3-2014$ & $20-3-2014$ & 2-4-2014 & $16-4-2014$ & $2-5-2014$ & $16-5-2014$ \\
\hline Referentie 3 & 90 & & 20 & 10 & 0 & 15 \\
\hline Drains 3 & 60 & & 5 & 5 & 5 & 15 \\
\hline Referentie 4 & 20 & & 10 & 0 & 0 & 10 \\
\hline Drains 4 & 15 & & 0 & 0 & 5 & 0 \\
\hline Referentie 5 & 50 & 30 & 10 & 10 & 10 & 15 \\
\hline Drains 5 & 10 & 0 & 10 & 5 & 5 & 5 \\
\hline Referentie 6 & 50 & 40 & 25 & 25 & 10 & 35 \\
\hline Drains 6 & 25 & 10 & 15 & 5 & 15 & 20 \\
\hline
\end{tabular}


Tabel 3-5 Grashoogten 2013, gemiddelde van 20 metingen per perceeldeel.

\begin{tabular}{|l|r|r|r|r|r|}
\hline \multicolumn{1}{|c|}{ 2013 } & 25 apr '13 & 3 mei '13 & 10 mei '13 & 24 mei '13 & 31 mei '13 \\
\hline Referentie 5 & 4.80 & 5.65 & 6.88 & 12.28 & 17.53 \\
\hline Drains 5 & 5.18 & 5.83 & 7.23 & 13.65 & 18.55 \\
\hline Referentie 6 & 4.70 & 5.73 & 7.75 & 14.38 & 19.28 \\
\hline Drains 6 & 4.40 & 5.70 & 7.50 & 12.95 & 16.75 \\
\hline
\end{tabular}

Tabel 3-6 Grashoogten 2014, gemiddelde van 20 metingen per perceeldeel.

\begin{tabular}{|l|c|c|c|c|}
\hline \multicolumn{1}{|c|}{ 2014 } & 16 apr '14 & 23 apr '14 & 2 mei '14 & 9 mei '14 \\
\hline Referentie 3 & 12.55 & & 24.15 & \\
\hline Drains 3 & 11.50 & & 23.75 & \\
\hline Referentie 4 & 8.63 & & 16.00 & \\
\hline Drains 4 & 8.68 & & 16.68 & \\
\hline Referentie 5 & 8.15 & 10.15 & 16.80 & 20.50 \\
\hline Drains 5 & 8.60 & 10.35 & 17.00 & 21.23 \\
\hline Referentie 6 & 10.98 & 13.10 & 22.95 & \\
\hline Drains 6 & 10.03 & 12.30 & 21.53 & \\
\hline
\end{tabular}




\section{Bijlage 4 Waterkwaliteit praktijkproef onderwaterdrains Wormer- Jisperveld}

\section{Praktijkproef onderwaterdrains \\ Wormer- en Jisperveld}

Deelonderzoek 'Waterkwaliteit'

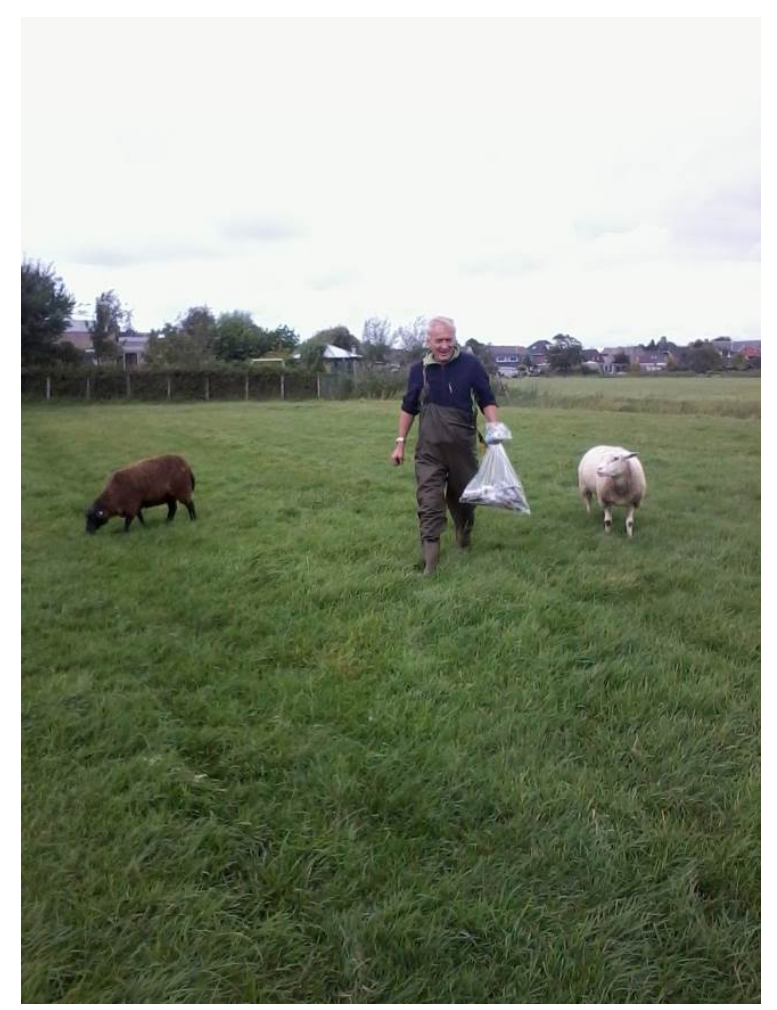


Niets uit dit rapport mag worden gereproduceerd, opnieuw vastgelegd, vermenigvuldigd of uitgegeven door middel van druk, fotokopie, microfilm, langs elektronische of elektromagnetische weg of op welke andere wijze dan ook zonder schriftelijke toestemming van de auteurs.

Titel rapport: Praktijkproef onderwaterdrains Wormer- en Jisperveld. Deelonderzoek 'waterkwaliteit'

Auteurs: J.M.H. van Diggelen, A.J.P. Smolders

Opdrachtgever: Hoogheemraadschap Hollands Noorderkwartier

Rapportnummer: 2015.55

Informatie:

\section{Bezoekadres}

B-WARE Research Centre

Radboud Universiteit Nijmegen

Toernooiveld 1

6525 ED Nijmegen

Tel: 024-3652816

info@b-ware.eu

\section{Postadres}

B-WARE Research Centre

Radboud Universiteit Nijmegen

Postbus 6558

6503 GB Nijmegen

(c) B-WARE Research Centre, Nijmegen, 2015. 


\section{Inleiding}

\section{Aanleiding en doel (deelonderzoek B-WARE)}

Dit project wordt uitgevoerd door Alterra, in samenwerking met Witteveen\&Bos en onderzoekcentrum B-WARE. Er wordt experimenteel onderzocht wat de effecten zijn van de toepassing van onderwaterdrains (OWD) in het Wormer- en Jisperveld, ten behoeve van het verminderen van bodemdaling en verbeteren van de waterkwaliteit. Onderzoekcentrum B-WARE heeft als onderdeel van dit onderzoek specifiek gekeken naar de effecten van OWD op de (bodem)waterkwaliteit.

De water- en bodemwaterkwaliteit zijn potentieel belangrijke indicatoren voor het bepalen van het effect van onderwaterdrains (OWD) op de oxidatie van veen. Het effect van OWD is waarschijnlijk veel sneller meetbaar in de verandering van de kwaliteit van het poriewater dan dat er sprake is van een meetbaar effect op de maaivelddaling (vaak pas na 5-10 jaar betrouwbaar meetbaar). Als door de verhoging van de grondwaterstanden in de zomer, als gevolg van OWD, de oxidatie in het veen afneemt, dan leidt dit naar verwachting ook tot een verbetering van de waterkwaliteit van het grondwater en daarmee ook van het oppervlaktewater. Tegelijkertijd is de oxidatie van veen ook weer afhankelijk van de kwaliteit van het oppervlaktewater dat via de drains in het veen wordt gebracht. Daarom is de afgelopen 2 jaar een monitoring van grondwater en oppervlaktewater in een proefperceel met OWD uitgevoerd door onderzoekcentrum B-WARE.

\section{Opzet monitoring waterkwaliteit}

Er werd in het Wormer- en Jisperveld een primaire proeflocatie ingericht waarin de helft werd ingericht met onderwaterdrains op $70 \mathrm{~cm}$ diepte die uitkwamen op een gescheiden slootcompartiment. Het andere (referentie) deel van de proeflocatie had geen onderwaterdrains, maar daar werd de reguliere drainage voorgezet welke uitkwam op een ander compartiment van dezelfde sloot. In figuur 1 is een schematische weergave te zien van de inrichting van het proefperceel, met hierop de monitorinslocaties. In het deel perceel waar de drains zijn aangebracht is er bemonsterd op 10, 25 en 40 meter afstand van de sloot (4 raaien); 2 raaien direct naast een drain (nr. 2-4-6, 8-10-12), en 2 raaien tussen 2 drains in (nr. 1-3-5, 7-9-11). In het deel perceel waar geen OWD is toegepast zijn ook 2 raaien bemonsterd op 10, 25 en 40 meter afstand van de sloot (nr. 13-14-15, 16-17-18). De bemonstering van het grondwater heeft gedurende 2 jaar (2013-2015) 2x per jaar plaatsgevonden, aan het einde van de natte winterperiode en aan het einde van de droge zomerperiode.

Het oppervlaktewater is om de week verzameld door een zeer behulpzame vrijwilligster; in het slootcompartiment zonder OWD (mengmonster van nr. 1-2-3), in het aanvoerwater (nr. 7), en in het slootcompartiment met OWD (mengmonster van nr. 4-5-6).

Tevens zijn er eenmalig op alle meetpunten bodemmonsters verzameld om de bodemkarakteristieken van de veenbodem in de twee deelpercelen in beeld te brengen. 


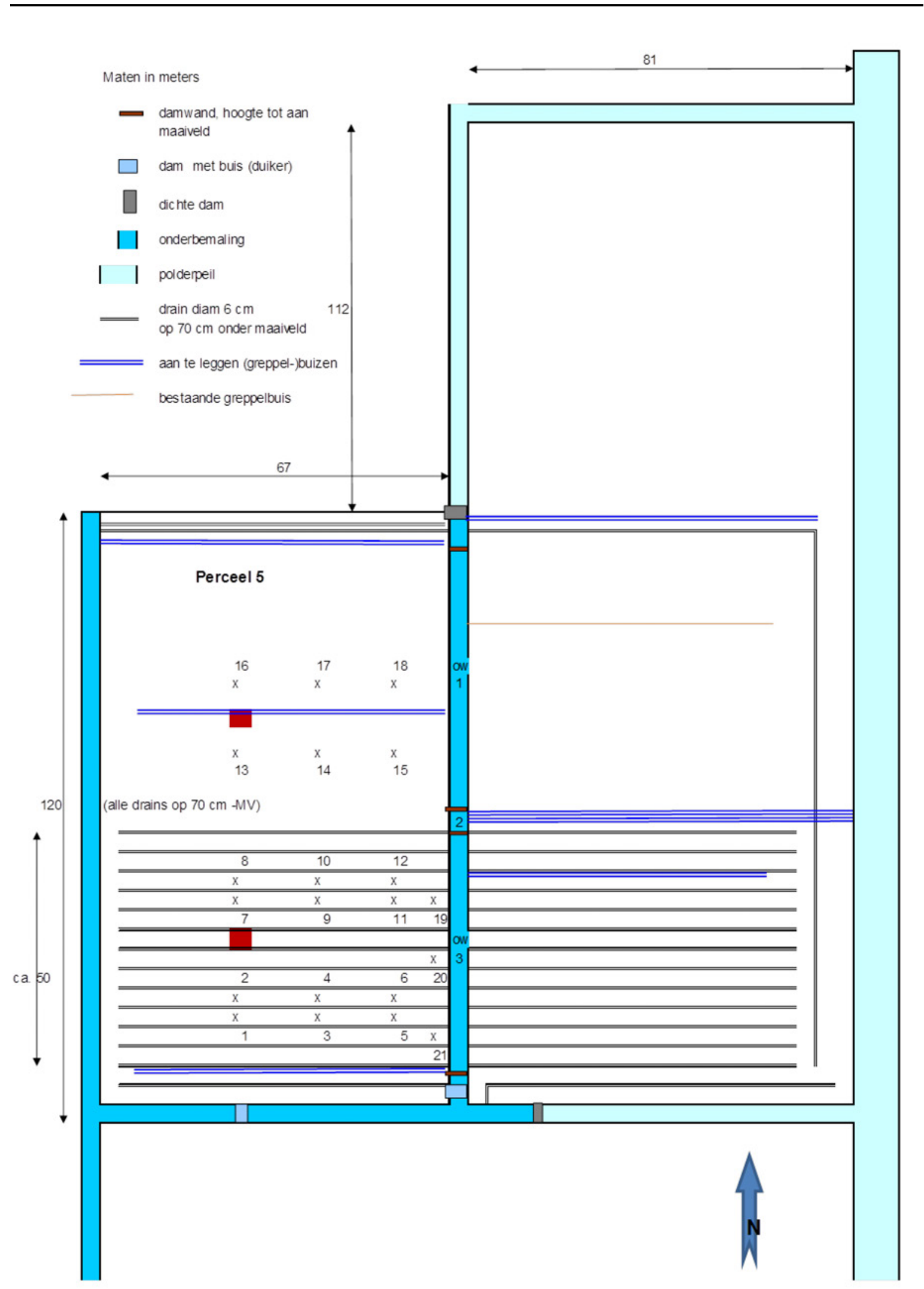

Figuur 1.Schematische weergave van het ingerichte proefperceel en de monsterlocaties. 

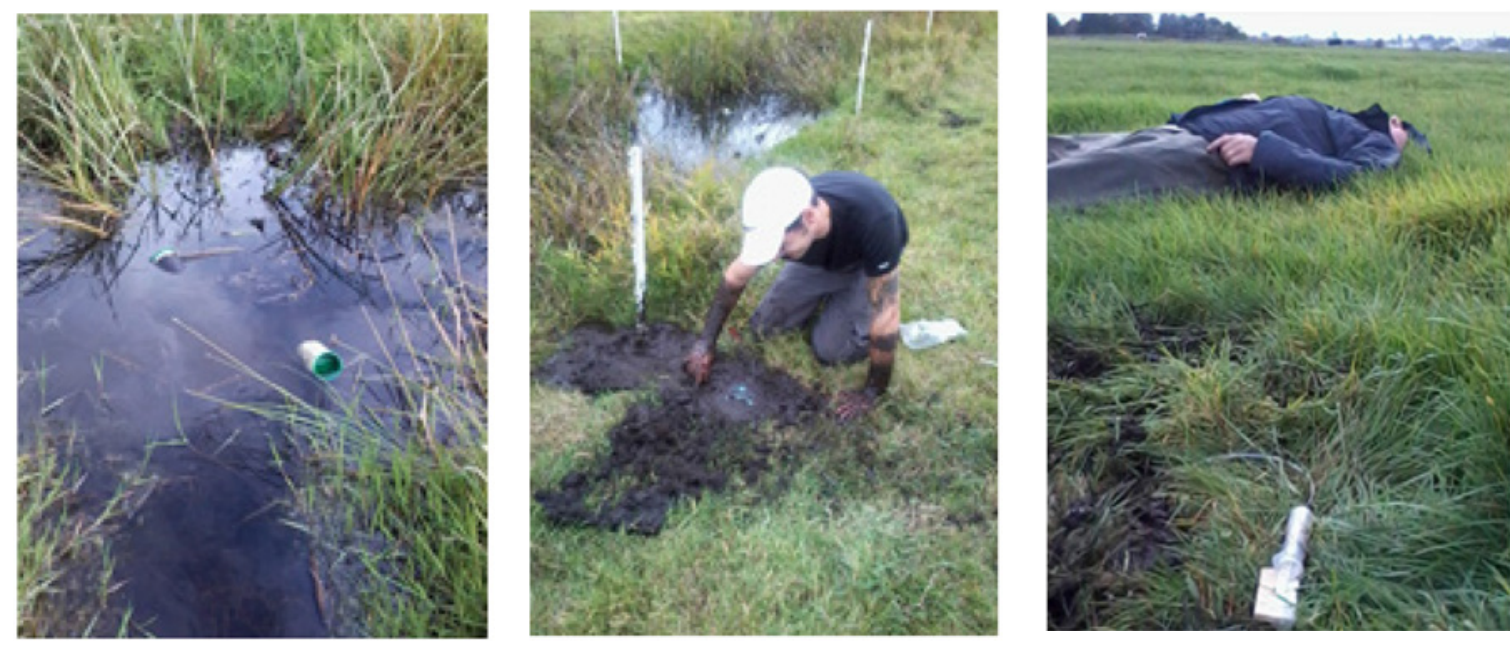

Figuur 2. Uiteinde van onderwaterdrains (OWD) die uitkomen in het oppervlaktewater van de aangrenzende sloot (links), effecten van bemonstering op de veldmedewerkers (midden en rechts).

\section{Resultaten}

\section{Bodemkarakteristieken onderzoek perceel}

Op alle monitoringslocaties in het proefveld, zowel in het deel met als het deel zonder onderwaterdrains (OWD), zijn eenmalig bodemmonsters verzameld van de toplaag om een idee te krijgen van de bodemkarakteristieken. De resultaten hiervan zijn weergegeven in tabel 1 , waar te zien is dat het deel van het proefperceel zonder OWD (-D) wat afwijkende bodemeigenschappen heeft ten opzichte van het deel van het proefperceel met OWD (+D). Zo zijn bijvoorbeeld de totaal-Fe en totaal-P gehaltes in de bodem zonder OWD structureel wat lager dan in het deel met OWD, de Fe:P ratio's op beide deel-percelen zijn echter wel vergelijkbaar. De totale hoeveelheid $S$ in de bodem lijkt juist wat hoger in het deel-perceel zonder OWD, waardoor de Fe:S ratio's in dit deel wat lager zijn. De Fe:S ratio is voor beide deelpercelen (met en zonder OWD) veel lager dan 1, wat betekent dat in deze bodems onder natte omstandigheden het overgrote deel van het aanwezig ijzer gebonden is aan gereduceerd zwavel. Bovendien valt het op dat de bodems op een halve meter van de sloot relatief lagere organische stofgehaltes (fractie OS), en hogere totaal-aluminium (Al), totaal-ijzer ( $\mathrm{Fe}$ ), totaal-fosfor $(\mathrm{P})$ en totaal-zwavel (S) gehaltes laten zien. Waarschijnlijk komt dit omdat de veenbodem direct grenzend aan de sloot het meest heeft bloot gestaan aan zuurstofrijkere omstandigheden. De meer zuurstofrijke omstandigheden aan de zijkanten van het perceel leiden tot een verhoogde afbraak van het veen (afname OS), en een verhoogde mineralisatie en inklinking van het veen door veenoxidatie die leiden tot relatief hogere gehalten van o.a. P, S en Fe in de oeverbodem. De oxidatieprocessen zijn netto ook verzurend waardoor calcium $(\mathrm{Ca})$ en magnesium $(\mathrm{Mg}) \mathrm{kan}$ uitspoelen uit de toplaag. Dit is te zien aan de lagere Ca concentratie in de bodem en de hogere $(\mathrm{Ca}+\mathrm{Mg})$ :Al ratio in de bodem op een halve meter uit de sloot.

Tabel 1. Gemiddelde bodemkarakteristieken van de verschillende meetpunten op de proeflocatie met (+D) en zonder $(-D)$ onderwaterdrains.

\begin{tabular}{|c|c|c|c|c|c|c|c|c|c|c|c|c|}
\hline & & & & $\mu \mathrm{mol} / \mathrm{kg} \mathrm{DW}$ & $\mu \mathrm{mol} / \mathrm{kg} \mathrm{DW}$ & $\mu \mathrm{mol} / \mathrm{kg} \mathrm{DW}$ & $\mu \mathrm{mol} / \mathrm{kg} \mathrm{DW}$ & $\mu \mathrm{mol} / \mathrm{kg} \mathrm{DW}$ & $\mu \mathrm{mol} / \mathrm{kg} \mathrm{DW}$ & & & \\
\hline Treatment & Afstand drain & Afstand sloot & fractie OS & Totaal-Al & Totaal-Ca & Totaal-Fe & Totaal-Mg & Totaal-P & Totaal-S & $\mathrm{Fe} / \mathrm{S}$ ratio & $\mathrm{Fe} / \mathrm{P}$ ratio & $\mathrm{Ca}+\mathrm{Mg} / \mathrm{Al}$ ratio \\
\hline$+D$ & direct naast drain & $0,5 \mathrm{~m}$ & 0,74 & 277195,5 & 414149,5 & 196338,2 & 163909,8 & 38528,2 & 590152,8 & 0,34 & 5,6 & 2,5 \\
\hline$+D$ & direct naast drain & $10 \mathrm{~m}$ & 0,86 & 82973,1 & 575637,5 & 68134,4 & 188988,9 & 13592,4 & 404577,6 & 0,17 & 5,0 & 9,3 \\
\hline$+D$ & direct naast drain & $25 \mathrm{~m}$ & 0,81 & 149095,2 & 589652,1 & 107745,7 & 211004,4 & 26183,4 & 398775,2 & 0,28 & 4,3 & 7,6 \\
\hline$+D$ & direct naast drain & $40 \mathrm{~m}$ & 0,77 & 200377,5 & 709722,9 & 130929,2 & 205421,5 & 18214,2 & 561008,1 & 0,22 & 6,7 & 6,6 \\
\hline$+D$ & tussen 2 drains & $10 \mathrm{~m}$ & 0,81 & 163001,5 & 614385,9 & 108364,3 & 192179,2 & 20009,4 & 393590,3 & 0,28 & 5,5 & 6,6 \\
\hline$+D$ & tussen 2 drains & $25 \mathrm{~m}$ & 0,82 & 158465,0 & 611375,0 & 118591,8 & 220374,9 & 19629,0 & 432869,9 & 0,27 & 6,0 & 5,5 \\
\hline$+D$ & tussen 2 drains & $40 \mathrm{~m}$ & 0,80 & 136074,9 & 774840,8 & 116576,8 & 204181,5 & 18195,0 & 495797,2 & 0,23 & 6,2 & 7,4 \\
\hline$-D$ & geen OWD & $10 \mathrm{~m}$ & 0,85 & 74352,4 & 630414,9 & 69668,8 & 220236,0 & 13745,4 & 540313,6 & 0,13 & 5,1 & 11,5 \\
\hline$-D$ & geen OWD & $25 \mathrm{~m}$ & 0,85 & 84271,3 & 575317,8 & 78871,4 & 246343,7 & 13186,3 & 472194,2 & 0,17 & 6,0 & 10,4 \\
\hline$-D$ & geen OWD & $40 \mathrm{~m}$ & 0,82 & 133287,3 & 658019,2 & 92207,7 & 244509,3 & 17702,2 & 506725,6 & 0,18 & 5,2 & 7,1 \\
\hline
\end{tabular}




\section{Effecten OWD op de grondwater kwaliteit}

Gedurende 2 jaar is het grondwater op $70 \mathrm{~cm}$ diepte in de veenbodem bemonsterd en geanalyseerd net na de winterperiode (OWD in perceel: afvoerfunctie), en aan het einde van de zomerperiode (OWD in perceel: aanvoerfunctie of eventueel afvoerfunctie in natte periodes). In figuur 3 wordt de chloride $(\mathrm{Cl})$ concentratie in het grondwater weergegeven in de tijd, welke kan worden gebruikt als een tracer voor de mate van de afvoer van (bodem)water richting de sloot. $\mathrm{Er}$ is in deze figuur goed te zien dat voor raai 1 met onderwaterdrains, gedurende beide winterperioden de $\mathrm{Cl}$ concentratie toeneemt in de drain en in het oppervlaktewater (blauwe lijn). Een dergelijke toename is ook zichtbaar in he grondwater direct naast de drain (doorlopende groene lijn). De $\mathrm{Cl}$ concentraties in het grondwater tussen de drains zijn jaarrond fors hoger dan de concentraties net naast de drains. De toename van de $\mathrm{Cl}$ concentraties bij de drain in de winterperiode kunnen dan ook verklaard worden door een toestroom van $\mathrm{Cl}$-rijk water uit de percelen naar de drains toe, in de natte periode. In de warmere en drogere perioden in het voorjaar en de zomer de zomer is het omgekeerde patroon te zien. Er is dan geen

neerslagoverschot meer en in plaats van uitspoeling uit de percelen naar de sloten toe is er dan eerder sprake van infiltratie. In de percelen met onderwaterdrains is deze infiltratie veel hoger. In deze periode van infiltratie wordt het water in de drain dus met name gevoed door het oppervlaktewater in de sloot. De $\mathrm{Cl}$ concentraties in het slootwater (ook in het inlaatwater) zijn in deze periodes veel lager dan in de percelen. Als gevolg hiervan zijn de $\mathrm{Cl}$ concentratie direct bij de drain juist lager na een periode met infiltratie. Het verloop van de concentraties bij de drains laat dus heel mooi het patroon van uitvoer en invoer van water in de percelen zien. Opvallend in figuur 3 is de sterke gradiënt van de $\mathrm{Cl}$ concentratie in de percelen, met de hoogste waardes op het midden van het perceel $(40 \mathrm{~m})$ en de laagste waardes dicht bij de slootrand $(10 \mathrm{~m})$. Dit geldt zowel voor de percelen met OWD als voor de percelen zonder OWD. Overigens zijn de gemeten concentraties ook erg hoog (op 40 meter uit de slootkant meer dan 40.000 $\mu \mathrm{mol} / \mathrm{L}$ ). De hoge $\mathrm{Cl}$ concentraties die gedurende grote delen van het jaar in het oppervlaktewater worden gemeten hangen zeer waarschijnlijk samen met de uitspoeling van $\mathrm{Cl}$ uit de percelen. Met name in periodes waarin er sprake is van uitspoeling vanuit de percelen is de $\mathrm{Cl}$ concentratie in het oppervlaktewater hoog. Dit is een regionaal fenomeen want ook het inlaatwater is dan erg rijk aan chloride. In periodes waarin er netto sprake is van infiltratie zijn de $\mathrm{Cl}$ concentraties veel lager. In deze periode waarin er geen water uitspoelt uit de percelen verdunnen de $\mathrm{Cl}$ concentraties in het oppervlaktewater blijkbaar (het is ook mogelijk dat er minder Cl-rijk water van buiten het peilvak wordt ingelaten). De gevonden gradiënt in het perceel zou kunnen worden veroorzaakt door uitspoeling van $\mathrm{Cl}$ naar het oppervlaktewater waardoor in het perceel een gradiënt ontstaat of doordat verder van de sloot af door transpiratie meer dieper Cl-rijk water omhoog komt. Overigens zien we dat in het grondwater van de percelen de $\mathrm{P}$-, ammonium $\left(\mathrm{NH}_{4}\right)^{-}$, $\mathrm{Ca}$-, en $\mathrm{Mg}$-concentratie sterk gecorreleerd is met de $\mathrm{Cl}$ concentratie (figuur 4). We zien voor $\mathrm{Ca}$ en $\mathrm{Mg}$ dat het verloop van de concentraties in de percelen en dichtbij de drainage buizen dan wel tussen de drainage buizen in grote lijnen hetzelfde beeld geeft als $\mathrm{Cl}$ (figuur 5).

Terwijl de $\mathrm{Cl}$ concentratie in het grondwater direct naast de drains gemeten bij raai 1 netjes meeloopt met de concentraties in de sloot en drainbuis, is dit bij raai 2 in veel mindere mate het geval. Dit zou kunnen betekenen dat de (in ieder geval infiltrerende) werking van de drain bij raai 2 veel minder goed was gedurende het onderzoek. Daarom worden hieronder de effecten van OWD in dit onderzoek vooral gebaseerd op de uitkomsten van raai 1 , en niet raai 2 . De grafieken van raai 2 zijn in de bijlagen terug te vinden.

Wat betreft de nutriënten concentraties in het grondwater is te zien dat ook de grondwater concentraties totaal-P en $\mathrm{NH}_{4}{ }^{+}$in het deel met OWD overal lager zijn dan in het deel zonder OWD en dat de concentraties direct naast de drain lager zijn dan tussen de drains (figuur 5). Met name in de zomermaanden, wanneer er aanvoer is van oppervlaktewater naar het perceel, is dit effect duidelijk terug te zien in zowel lagere concentraties van totaal-P als $\mathrm{NH}_{4}{ }^{+}$. De $\mathrm{NH}_{4}{ }^{+}$concentratie volgt hierbij goed de concentratie van het oppervlaktewater, maar dit geldt niet voor $\mathrm{P}$. De ortho-P concentraties in het oppervlaktewater zijn steeds hoger dan de concentraties die worden gemeten in het grondwater. Dit duidt er op dat het $\mathrm{P}$ dat binnenkomt via de drains rondom de drainagebuizen wordt geïmmobiliseerd in de veenbodem. 


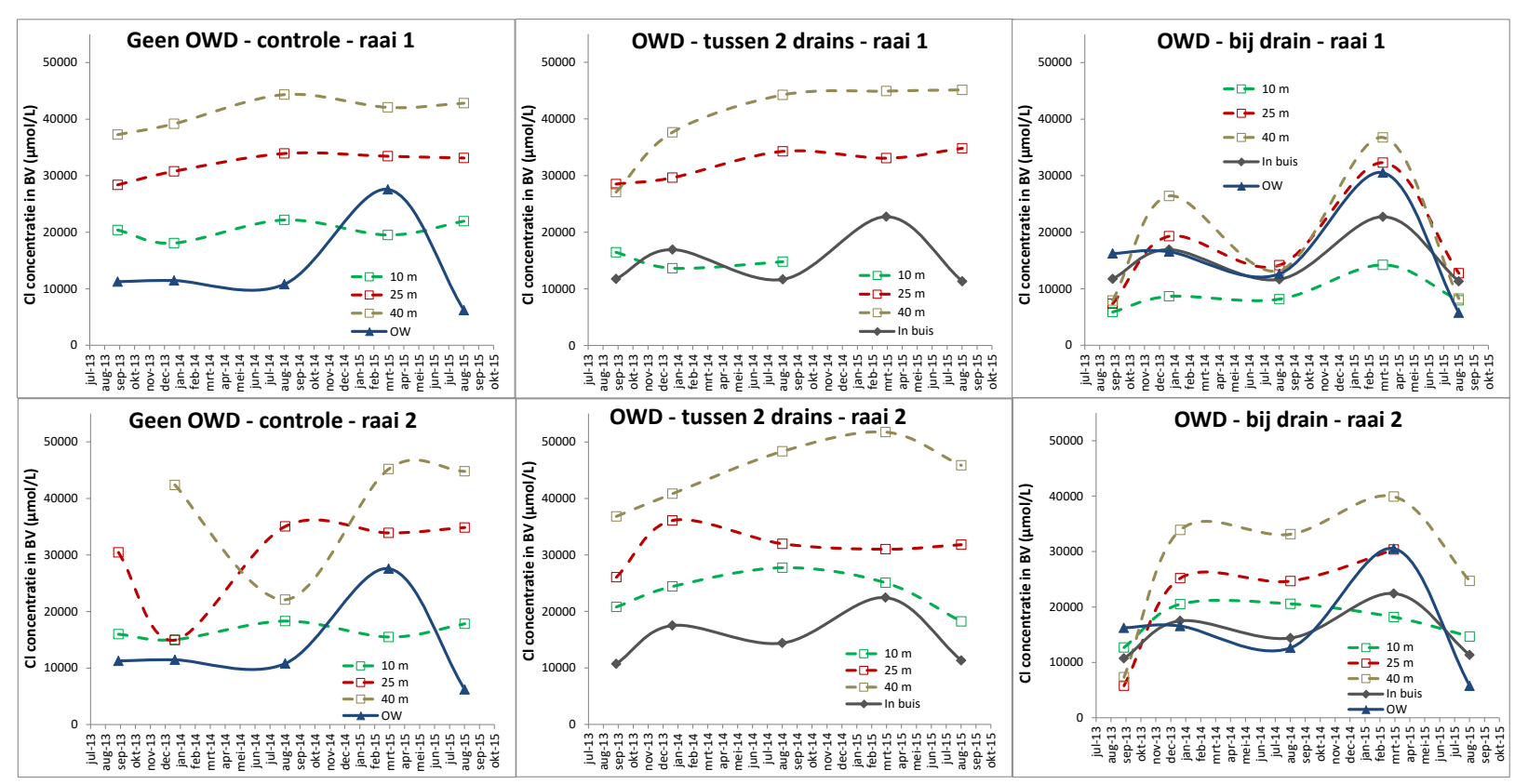

Figuur 3. Chloride concentraties $(\mathrm{Cl})$ in het bodemvocht op $70 \mathrm{~cm}$ diepte (ter hoogte van de drains), zowel in het deel-perceel zonder drains (linker panelen), direct naast de drain (rechter panelen), en tussen 2 drains in (middelste panelen). De 3 gestippelde lijnen geven de afstand vanaf de sloot aan (10, 25 of 40 meter). De blauwe en grijze lijn geven resp. de concentraties aan in het oppervlaktewater van de sloot en in de drainbuis zelf (referentiewaarden).

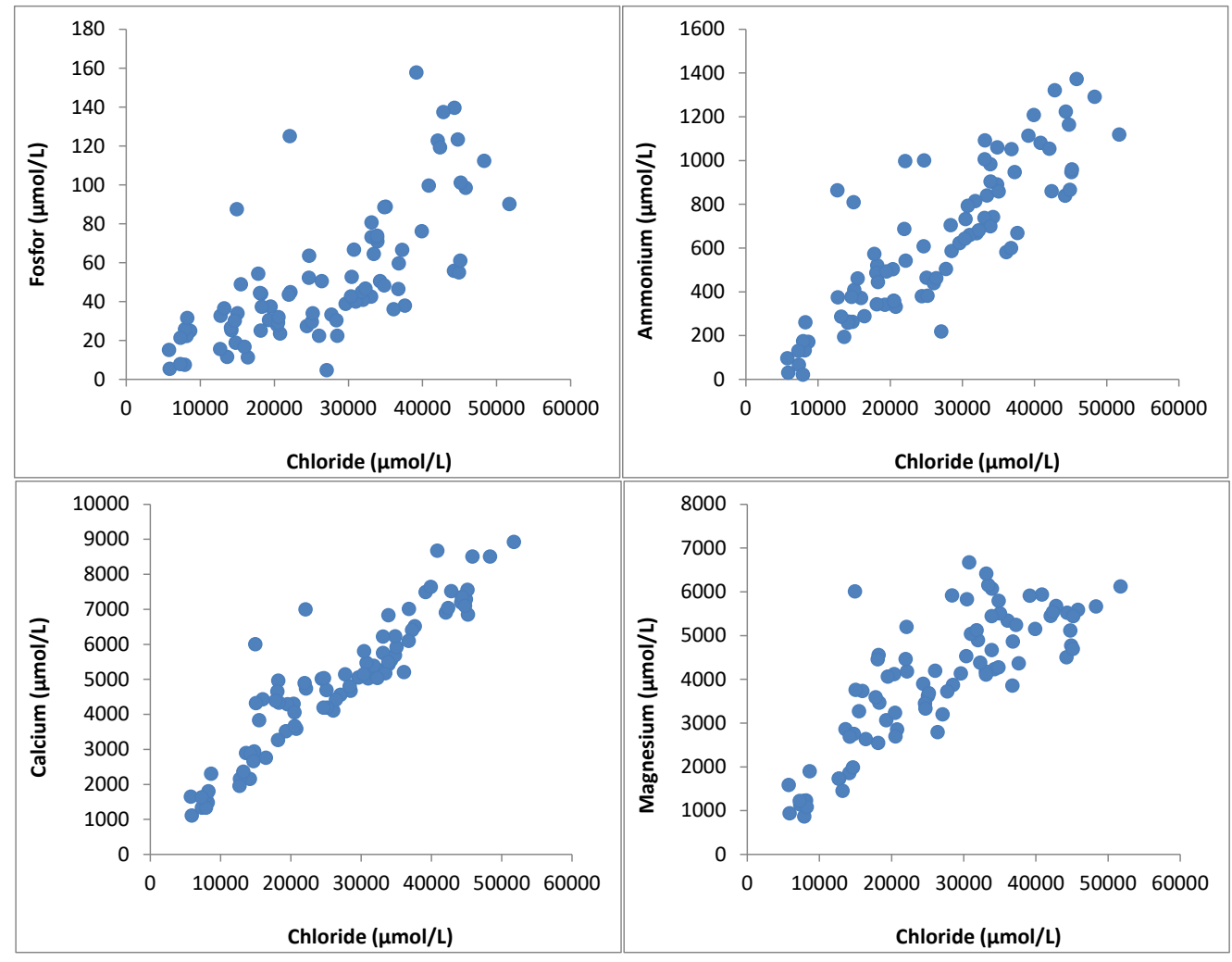

Figuur 4. Relatie tussen de fosfor-, ammonium- calcium- en magnesiumconcentratie en de chlorideconcentratie in het bodemwater van de percelen. 


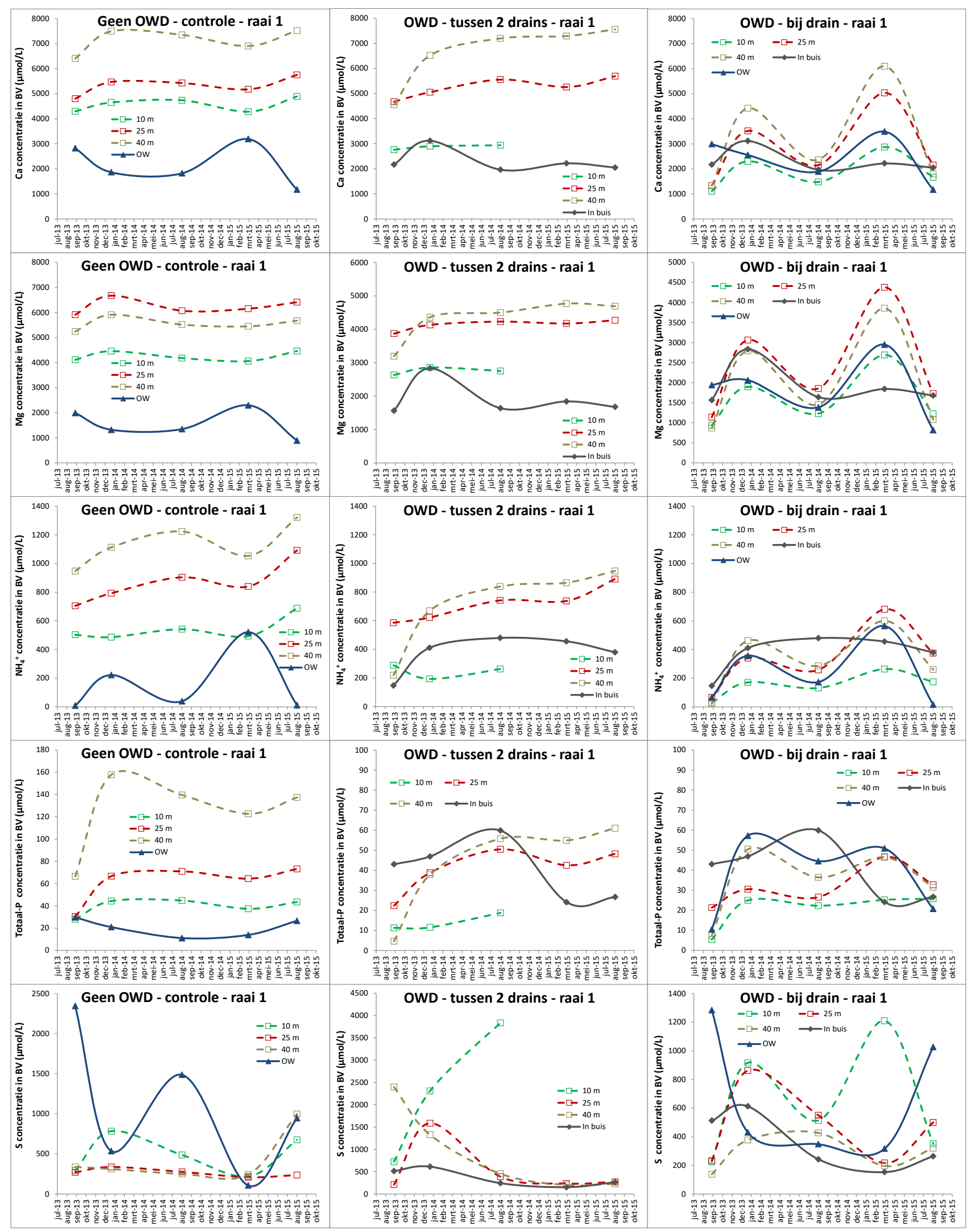

Figuur 5. $\mathrm{Ca}, \mathrm{Mg}, \mathrm{NH}_{4}{ }^{+}$, totaal-P en sulfaat (S) concentraties in het grondwater op $70 \mathrm{~cm}$ diepte (ter hoogte van de drains), zowel in het deel-perceel zonder drains (linker panelen), direct naast de drain (rechter panelen), en tussen 2 drains in (middelste panelen). De 3 gestippelde lijnen geven de afstand vanaf de sloot aan (10, 25 of 40 meter). De blauwe en grijze lijn geven resp. concentraties aan in het oppervlaktewater van de sloot en in de drainbuis zelf.

Het verloop van de S concentratie in het grondwater volgt ten dele het patroon dat voor $\mathrm{Cl}$, $\mathrm{Ca}$ en $\mathrm{Mg}$ wordt gevonden (figuur 5). Het verschil is echter dat de S concentraties in afvoer periodes veelal lijken te worden beïnvloed door de grondwaterconcentraties gemeten in het midden van het perceel en gedurende aanvoer periodes door de S concentraties in het oppervlaktewater. 
Overigens vertonen de $S$ concentraties ook tussen de drainage buizen en op de locaties zonder drainage buizen een grote variatie over de meetperiode. Dit verloop is niet onmiddellijk goed te verklaren maar wordt mede bepaald door oxidatie en reductieprocessen in het veen. De grondwatermonsters werden verzameld op een diepte van $70 \mathrm{~cm}$ terwijl de oxidatieprocessen waarbij S vrijkomt met name ook plaatsvinden in de hierboven liggende bodem. Onder natte omstandigheden kan sulfaat (geoxideerd S) door reductieprocessen ook worden gereduceerd tot sulfide.

\section{Effecten OWD op het oppervlaktewater in de aangrenzende sloot}

Het verloop van de kwaliteit van het water in de sloot met OWD komt sterker overeen met de kwaliteit van het inlaatwater uit de aanvoersloot, dan het verloop van de slootwaterkwaliteit zonder OWD (figuren 6 en 7). Dit hangt waarschijnlijk samen met de hogere inlaatbehoefte, met name in droge periodes, in de sloot met OWD. Overwegend vindt er echter zowel in de situatie met OWD als in de situatie zonder OWD afvoer plaats van water van de percelen. Voor de tijdstippen waarop we watermonsters uit de percelen hebben verzameld was er steeds sprake van netto afvoer van water uit de percelen. Aan de hand van de gemeten concentraties in de percelen en berekende invoer en uitvoer in de percelen (data Jan van den Akker) hebben we voor de 15 dagen voorafgaande aan de bemonstering de gemiddelde afvoer dan wel invoer uit de percelen berekend (tabel 2). Op alle vier de tijdstippen bleek er overigens sprake te zijn van afvoer (met een verschil in de mate van afvoer). Voor de berekening hebben we voor de afvoer via drainage buizen gerekend met de gemiddelde concentratie gemeten op 10, 25 en 40 meter direct langs de drains. Voor de afvoer via het perceel hebben we steeds gerekend met de gemiddelde concentraties (zowel voor de percelen met OWD als de percelen zonder OWD) op 10 $\mathrm{m}$ afstand van de slootoever. Uiteraard is het zeer de vraag of deze concentraties representatief zijn voor de concentraties in het water dat uit de percelen uitspoelt. Alle metingen zijn immers gedaan op $70 \mathrm{~cm}$ diepte (op de diepte waarop de drains liggen).

De $S$ concentraties in het oppervlaktewater laten hoge pieken zien aan het einde van de zomer wanneer de neerslag ook hoog is (figuur 7). De berekende belasting van $S$ uit het perceel neemt ook toe wanneer de neerslag toeneemt, met name in augustus (tabel 2). Er vindt dus duidelijk uitspoeling van $\mathrm{S}$ plaats uit de percelen. Over het algemeen zijn de $\mathrm{S}$ concentraties lager in de sloten zonder OWD. In periodes waarin er sprake is van een verhoogde uitspoeling van $S$ nemen de concentraties echter sterker toe in de sloot zonder OWD terwijl de berekende flux vanuit de percelen vergelijkbaar of lager is. Door de toepassing van OWD heeft de sloot een potentieel efficiëntere afvoerende functie, waardoor de sloot mogelijk ook harder wordt doorgespoeld gedurende natte perioden. Bovendien is de $\mathrm{S}$ reductie in de zomer hoog, waardoor de $\mathrm{S}$ concentratie kan afnemen in het oppervlaktewater. In de wintermaanden zijn de $S$ concentraties lager dan in de drogere zomermaanden omdat de $S$ uitspoeling beperkt is. Waarschijnlijk wordt de uitspoeling van $S$ ook bepaald door oxidatieprocessen in de oevers van de sloten en verderop het perceel. De pieken van de S concentraties in het oppervlaktewater zijn namelijk veel hoger dan de gemeten concentraties in de percelen op een diepte van $70 \mathrm{~cm}$. Lokaal kan er door oxidatie van veen veel S vrijkomen, zowel verder in het perceel als dichter bij de oevers, waar in ons onderzoek niet gemeten is. 


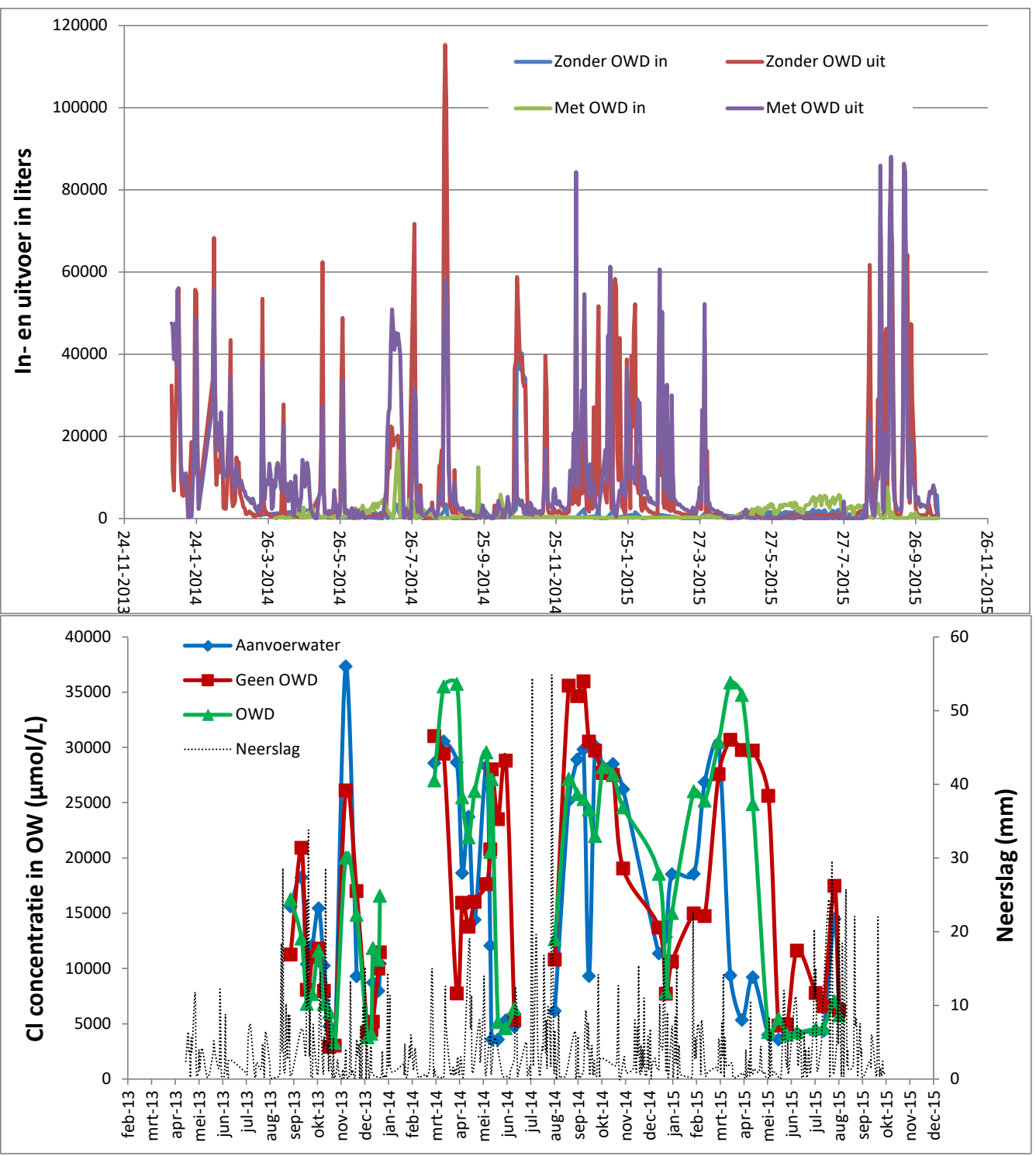

Figuur 6. Boven: De berekende invoer en uitvoer in de percelen (data Jan van den Akker). Onder: De chlorideconcentratie $\left(\mathrm{Cl}^{-}\right)$in het oppervlaktewater van de sloten grenzend aan de proefpercelen met en zonder OWD, en in de aanvoersloot (naar de sloot met OWD). De stippellijn geeft de hoeveelheid neerslag $(\mathrm{mm})$ weer in dezelfde monitoringsperiode. (Let op; de $\mathrm{x}$-as verschilt).

Wanneer de belasting van $\mathrm{P}$ en anorganisch $\mathrm{N}$ (nitraat $\left(\mathrm{NO}_{3}\right)+\mathrm{NH}_{4}$ ) vanuit het perceel naar de sloot wordt berekend (tabel 2), blijkt dat de belasting lager is met OWD. Hierbij spelen waarschijnlijk echter de verschillen tussen de percelen een grote rol. In de percelen zonder OWD zijn de gemeten $\mathrm{P}$ concentraties op $70 \mathrm{~cm}$ diepte in de percelen hoger dan in de percelen met OWD, ook tussen de drainagebuizen in. In grote lijnen volgen de totaal-P en fosfaat $\left(\mathrm{PO}_{4}{ }^{3-}\right)$ concentraties in het oppervlaktewater van de sloot ook de concentraties die worden gemeten in het inlaatwater van de aanvoerende sloot. In de droge zomerperiode van 2015 zijn de $\mathrm{P}$ en $\mathrm{PO}_{4}$ concentraties lager in de OWD sloot omdat er dan meer water wordt ingelaten met een lagere $P$ concentratie. In de sloot zonder OWD zijn de P concentraties dan veel hoger dan in het inlaatwater en in de sloot met OWD, waarschijnlijk als gevolg van isolatie waardoor nalevering vanuit de bodem leidt tot accumulatie van $\mathrm{P}$ in het water.

De $\mathrm{NO}_{3}$ - en $\mathrm{NH}_{4}$-concentraties zijn lager in de zomermaanden omdat er dan meer stikstof uit het systeem verdwijnt door gekoppelde nitrificatie-denitrificatie. Ook hier volgt het verloop van de concentratie in de sloot met OWD het patroon dat wordt gevonden in het inlaatwater van de aanvoerende sloot. In de sloot zonder OWD zijn de gemeten $\mathrm{NO}_{3}$-concentraties in de zomer vaak lager. Dit ondanks dat er een hogere flux wordt berekend vanuit de percelen. 


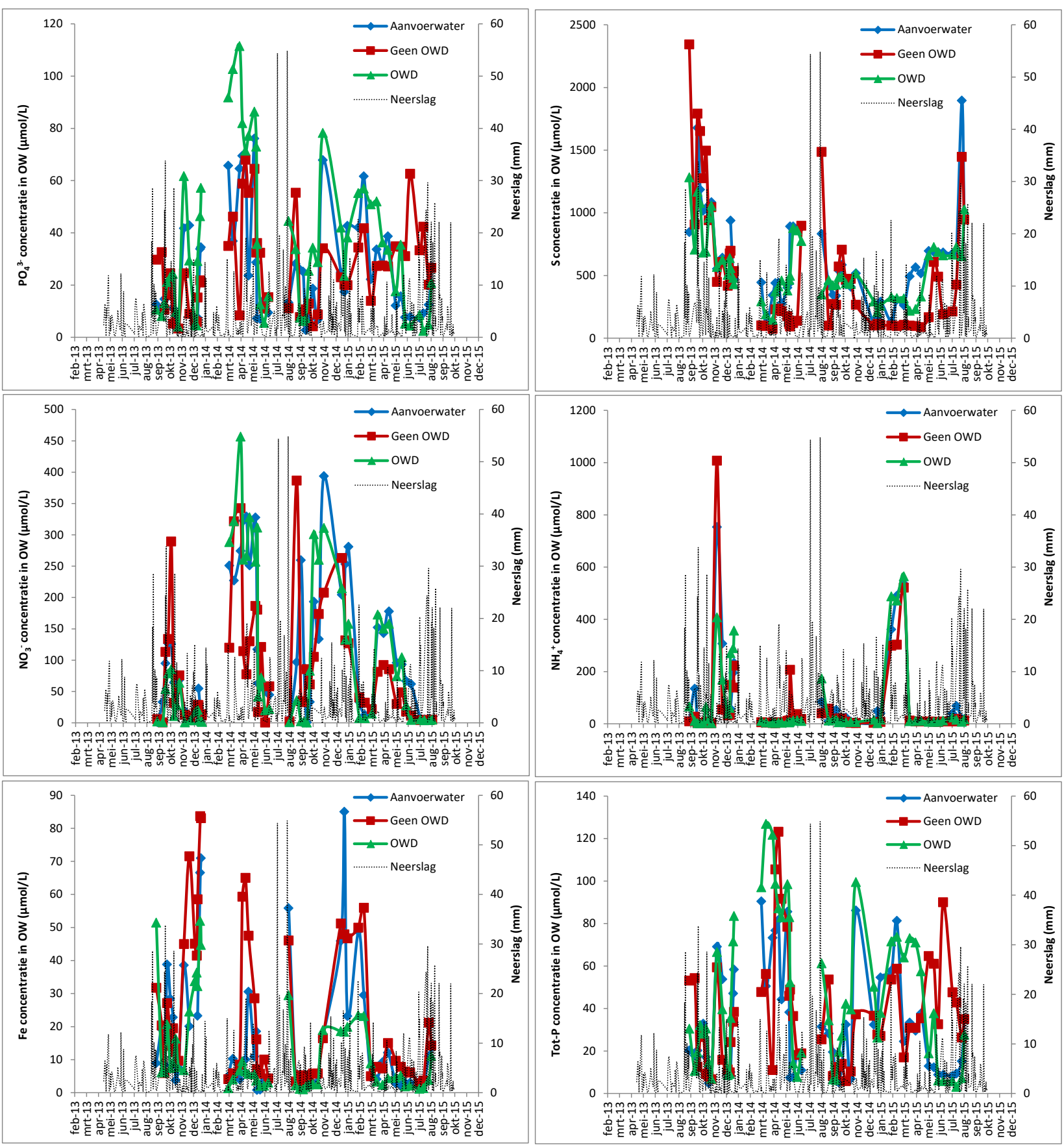

Figuur 7. De totaal-fosfor (tot-P), fosfaat $\left(\mathrm{PO}_{4}{ }^{3-}\right)$, sulfaat (S), ijzer (Fe), ammonium $\left(\mathrm{NH}_{4}^{+}\right)$en nitraatconcentratie $\left(\mathrm{NO}_{3}{ }^{-}\right)$in het oppervlaktewater van de sloten grenzend aan de proefpercelen met en zonder OWD, en in de aanvoersloot (naar de sloot met OWD). De stippellijn geeft de hoeveelheid neerslag (mm) weer in dezelfde monitoringsperiode. 
Tabel 2. Flux belasting van N, P, Fe, S en Cl naar het oppervlaktewater in de aangrenzende sloot met en zonder OWD. Via drainage buizen : aanname dat alles via de buizen is afgevoerd. Via perceel: aanname dat alles via het perceel is afgevoerd.

\begin{tabular}{|c|c|c|c|c|c|}
\hline & Anorg. N & totaal-P & $\mathrm{Fe}$ & $\mathbf{S}$ & $\mathrm{Cl}$ \\
\hline & $\mathrm{mmol} / \mathrm{dag}$ & $\mathrm{mmol} / \mathrm{dag}$ & $\mathrm{mmol} / \mathrm{dag}$ & $\mathrm{mmol} / \mathrm{dag}$ & $\mathrm{mmol} / \mathrm{dag}$ \\
\hline \multicolumn{6}{|l|}{ Met OWD } \\
\hline \multicolumn{6}{|l|}{ Via drainagebuizen } \\
\hline jan-14 & 6813 & 734 & 268 & 14939 & 376609 \\
\hline aug-14 & 4965 & 625 & 196 & 10923 & 260523 \\
\hline mrt-15 & 624 & 48 & 9 & 655 & 33589 \\
\hline aug-15 & 9908 & 1081 & 128 & 14080 & 348104 \\
\hline \multicolumn{6}{|l|}{ Via Perceel } \\
\hline jan-14 & 10112 & 635 & 68 & 3862 & 537579 \\
\hline aug-14 & 7813 & 655 & 110 & 12371 & 271403 \\
\hline mrt-15 & 620 & 35 & 64 & 1059 & 36945 \\
\hline aug-15 & 7910 & 536 & 135 & 44025 & 524269 \\
\hline \multicolumn{6}{|l|}{ Zonder OWD } \\
\hline \multicolumn{6}{|l|}{ Via Perceel } \\
\hline jan-14 & 9314 & 813 & 233 & 11752 & 344142 \\
\hline aug-14 & 10877 & 901 & 178 & 10613 & 444853 \\
\hline mrt-15 & 583 & 52 & 22 & 265 & 21180 \\
\hline aug-15 & 22888 & 1763 & 708 & 19501 & 717273 \\
\hline
\end{tabular}




\section{Conclusies 'Effecten van OWD op de waterkwaliteit'}

- De toepassing van OWD lijkt jaarrond een effect te hebben op de grondwaterkwaliteit. De concentraties van alle ionen worden verlaagd in de zomerperiode waarin er sprake is van infiltratie van oppervlaktewater.

- Dit effect is echter alleen meetbaar direct bij de OWD buizen. Tussen de drains in (deze liggen steeds 4 meter uit elkaar) is het effect niet meer meetbaar.

- Van de twee drains die we in dit onderzoek hebben gemonitord laat 1 drain dit effect duidelijk zien, de andere niet. Dit doet vermoeden dat niet alle drains even goed hebben gewerkt.

- De verschillen tussen de deelpercelen met en zonder OWD zijn erg groot waardoor het niet mogelijk is om het effect van OWD op de uitspoeling van nutriënten hard te maken. De berekeningen die we hebben kunnen maken laten, voor wat ze waard zijn, zien dat OWD niet leidt tot een verhoogde uitspoeling van stikstof en fosfor.

- De effecten van OWD op de oppervlaktewaterkwaliteit worden sterk bepaald door de mate waarin er aanvoer van water nodig is in de droge tijd (waarin er infiltratie plaatsvindt van oppervlaktewater in de percelen). De toepassing van OWD heeft hierdoor wel invloed op de oppervlaktewaterkwaliteit.

- $E r$ is een sterke gradiënt van de ionenconcentraties (chloride, calcium, magnesium, ammonium en fosfor) in de percelen van het midden naar de rand. Concentraties nemen richting het midden van het perceel steeds verder toe vanaf de sloot waar de oppervlaktewaterkwaliteit werd gemeten. Dit geldt zowel voor het deelperceel met OWD als zonder OWD.

- Uitspoeling van ionen en nutriënten uit het perceel is sterk bepalend voor de oppervlaktewaterkwaliteit in het gebied. 


\section{Bijlagen}
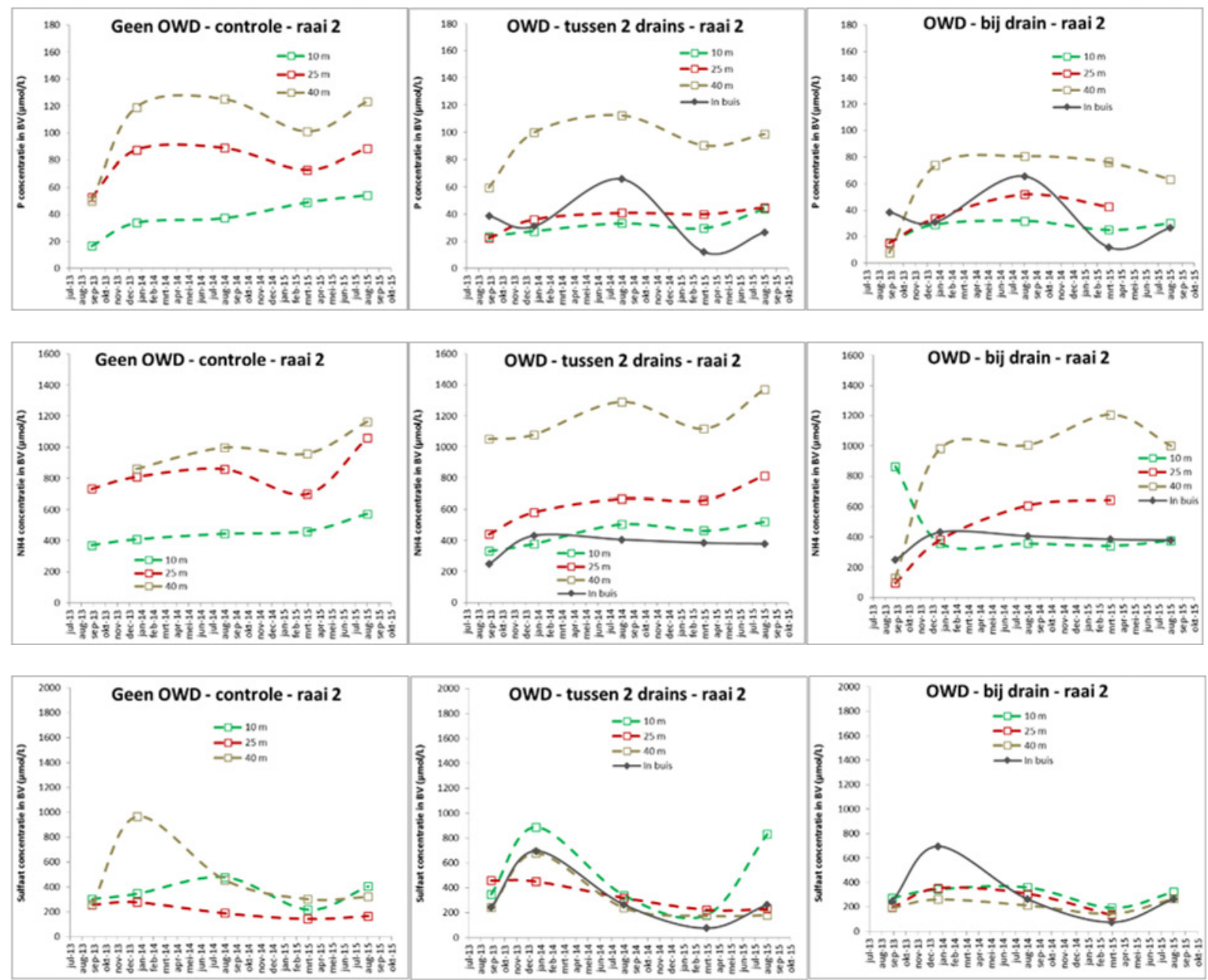
Wageningen Environmental Research Postbus 47

6700 AA Wageningen

T 0317480700

www.wur.nl/environmental-research

Wageningen Environmental Research Rapport 2765

ISSN 1566-7197
De missie van Wageningen University \& Research is 'To explore the potential of nature to improve the quality of life'. Binnen Wageningen University \& Research bundelen Wageningen University en gespecialiseerde onderzoeksinstituten van Stichting Wageningen Research hun krachten om bij te dragen aan de oplossing van belangrijke vragen in het domein van gezonde voeding en leefomgeving. Met ongeveer 30 vestigingen, 5.000 medewerkers en 10.000 studenten behoort Wageningen University \& Research wereldwijd tot de aansprekende kennisinstellingen binnen haar domein. De integrale benadering van de vraagstukken en de samenwerking tussen verschillende disciplines vormen het hart van de unieke Wageningen aanpak. 



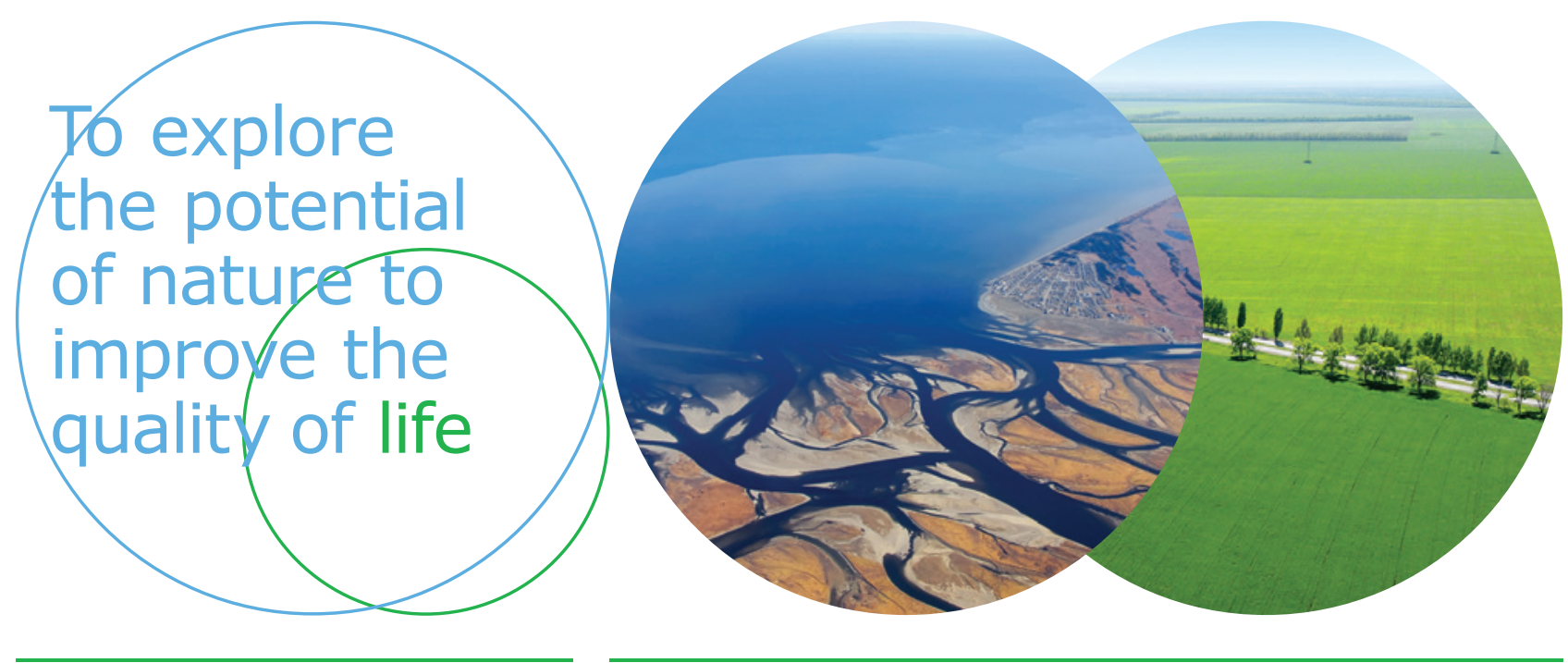

Wageningen Environmental Research Postbus 47

$6700 \mathrm{AB}$ Wageningen

T 317480700

www.wur.nl/environmental-research

Rapport 2765

ISSN 1566-7197
De missie van Wageningen University \& Research is 'To explore the potential of nature to improve the quality of life'. Binnen Wageningen University \& Research bundelen Wageningen University en gespecialiseerde onderzoeksinstituten van Stichting Wageningen Research hun krachten om bij te dragen aan de oplossing van belangrijke vragen in het domein van gezonde voeding en leefomgeving. Met ongeveer 30 vestigingen, 5.000 medewerkers en 10.000 studenten behoort Wageningen University \& Research wereldwijd tot de aansprekende kennisinstellingen binnen haar domein. De integrale benadering van de vraagstukken en de samenwerking tussen verschillende disciplines vormen het hart van de unieke Wageningen aanpak. 